\author{
UNIVERSIDAD SANTO TOMÁS \\ FACULTAD DE DERECHO \\ MAESTRÍA EN DERECHO PÚBLICO
}

\title{
CRISIS DE REPRESENTACIÓN COMO CONSECUENCIA DEL TRANSFUGUISMO POLÍTICO EN COLOMBIA
}

\author{
AUTOR \\ VICENTE ANIBAL OJEDA MARTÍNEZ
}

TUTORA

MILENA PACHECO

BOGOTA, D.C., 2016 


\section{Contenido}

Introducción.

1. Capítulo I. Caracteristicas de la representacion politica y su relacion con el sistema de partidos.

1.1 Perspectivas teóricas y evolución de la Representación Política......

1.2 Evolución histórica y teórica sobre partidos políticos y su sistema en Francia y Estados

Unidos.

1.2.1. Francia

1.2.2. Estados Unidos

1.3 Representación política, democracia y gobiernos representativos. .35

1.3.1 Estudio de los Partidos Políticos.

1.3.2 Importancia y funciones de los partidos políticos. .46

1.4 Nociones sobre Sistemas de Partidos y sus tipologías. .50

1.4.1 Cambios en los Sistemas de partidos .53

1.5 Crisis de Representación Política. .55

2. Capítulo II. El trasfuguismo político y sus consecuencias en la representación de los partidos políticos .63

2.1 Transfuguismo Político. .63

2.1.1 Introducción y antecedentes al fenómeno del transfuguismo político.

2.1.2 Conceptos del Transfuguismo político

2.1.3 Causas y Justificación del transfuguismo. .70

2.1.4 Doble militancia y Transfuguismo político. Aproximaciones jurídicas .73

2.2 Sistema de Partidos en Latinoamérica.

2.2.1 Cambios en la representación de los partidos: "Sistema de partidos en Chile y México". .79

2.2.2 Cambios en la representación de los partidos: "Sistema de partidos en Colombia".83 
2.3 Polarización y competencia en los sistemas de partidos latinoamericanos

2.4 Marco Jurídico, legal y constitucional de los partidos políticos en Chile, México y

Colombia.....

3. Capítulo III: Aproximaciones normativas para combatir el transfuguismo político en Colombia y la relevancia de los movimientos sociales como nuevos mecanismos de representación.

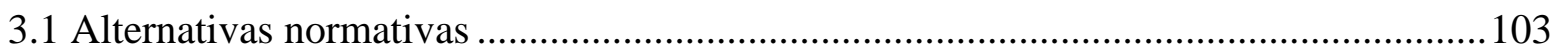

3.1.1 Análisis Jurídico del marco normativo vigente Frente al Trasfuguismo. ...............103

3.1.2 Modificaciones a la Ley de Bancadas ................................................................ 113

3.2 Movimientos Sociales como mecanismos de representación ...................................... 122

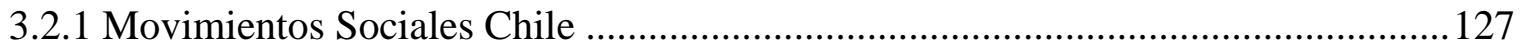

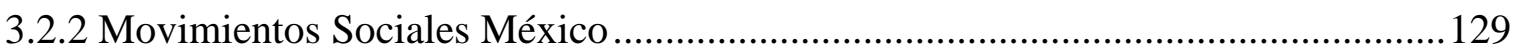

3.2.3 Movimientos Sociales en Colombia................................................................ 137

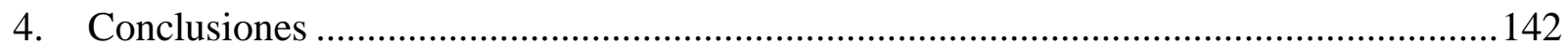

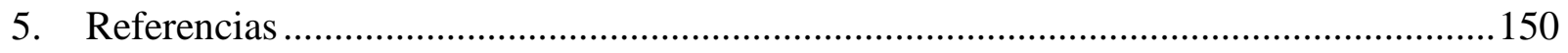

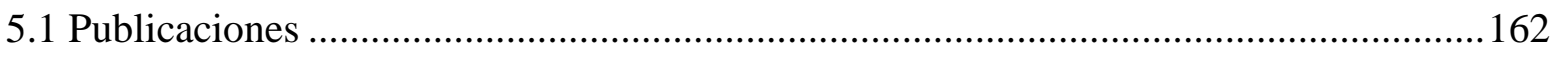

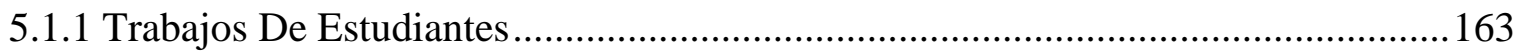

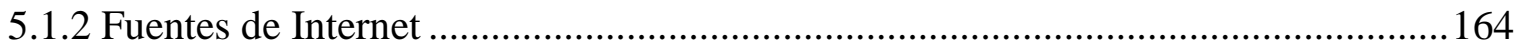




\section{Lista de Tablas}

Tabla 1. Año de ingreso constitucional de los partidos políticos $\quad$.....50

Tabla 2. Funciones Partidos Políticos $\quad$.....51

Tabla 3. Partidos Políticos con personería jurídica vigente en

Colombia (2010-2014)

$\ldots .77$

Tabla 4 Partidos y movimientos políticos con escaños en Congreso (2010-2014) ......78

Tabla 5.Volatilidad Electoral Colombia, Chile, México $\quad$ …93

Tabla 6. Definición de Partido Político según la legislación $\quad$.....96

Tabla 7. Funciones partidos políticos de acuerdo a su legislación $\quad$.....97

Tabla 8.Regulación de los partidos en la Constitución Política $\quad$ ….97

Tabla 9.Leyes especiales partidos políticos $\quad$ _...99

Tabla 10.Libertades en la constitución partidos políticos $\quad$ …99

Tabla 11.Estructura interna de los partidos - Normatividad $\quad$.....100

Tabla 12.Votación mínima para evitar cancelación de partidos $\quad$.....101 
CRISIS DE REPRESENTACIÓN COMO CONSECUENCIA DEL TRANSFUGUISMO POLÍTICO EN COLOMBIA

\section{Lista de Figuras}

Figura 1. Mejoramiento de la Democracia $\quad$ _....48

Figura 2. Falta reducir la corrupción- Qué le falta a la democracia en su país? 


\section{Introducción}

Esta investigación en torno al transfuguismo electoral, busca evidenciar secuelas provenientes de cambios históricos, que se reflejan a nivel mundial, y que han provocado resultados nocivos en nuestro país, como se podrá observar en el desarrollo de este documento. Por mencionar alguno de ellos, se puede exponer la distancia y grandes diferencias que los ciudadanos han tomado frente los estamentos partidistas generando un marcado desinterés en asuntos políticos y una incredulidad hacia las autoridades estatales y las instituciones en general. Tanto es así que, los ciudadanos que accedieron a la vida política en los últimos comicios, se involucraron más por intereses personales que por el bien común, principal tarea y virtud de la labor política.

Si bien es cierto que en la democracia actual el ciudadano tiene derechos y obligaciones, es evidente que la realidad es otra ya que los individuos no cuentan con representación real que los lleve a la satisfacción de sus necesidades y la convalidación de sus derechos. Es por ello que se debe compensar la falta de presencia en los partidos políticos porque es, a través de ellos, que se ejerce el derecho y deber ciudadano en las democracias modernas y es, precisamente en los partidos, donde se producen representantes que hacen eco de estos requerimientos del ciudadano.

De esta forma, para reparar los resultados negativos y aumentar los cambios positivos, se debe propender por una reconfiguración política tomando como base una forma de reintegración de los componentes que configuran las percepciones ciudadanas por medio del espacio público. De este modo, se da una contestación a la falta de representación lo que deviene en una mayor participación en los programas públicos, así como una mayor inclusión de los sujetos en la toma de decisiones. 
Así mismo se debe involucrar las condiciones que aumenten la credibilidad y la convivencia general con los partidos políticos, de tal manera que, el miedo o la desconfianza a los sistemas de partidos, disminuya incrementando la participación, interrelación y opinión del ciudadano hacia el partido de su elección. Esta reconfiguración, que necesita de la unión de diversas acciones, se revisa y analiza en la presente investigación.

Desde la antigua Grecia, hasta nuestros días, el hombre ha venido desarrollando formas de organización política de los pueblos aplicando, para ello, varios sistemas políticos con gobiernos que, pudieron ser o no, representativos de la comunidad y que no siempre tuvieron como finalidad el bien común de sus gentes.

Con posterioridad, al instaurarse como sistema político las Monarquías, los reyes contaban con un poder omnímodo que poco a poco se limitó al ir aumentando la sensibilidad humana frente el abuso ejercido por éstos y que, al generar inconformidad en los asociados, aumentó con mayor énfasis las críticas hacia los gobiernos monárquicos, confluyendo en manifestaciones que terminaron en revoluciones como las sucedidas en Inglaterra, Francia, Estados Unidos, entre otras.

Estas revoluciones mostraron sellos propios en el desarrollo su práctica y consolidación, lo que llevó a realizar un pequeño estudio de diferentes partidos políticos y sus sistemas a nivel general y que, en el siglo XIX, se evidenciaron en las sociedades industrializadas y de masas, y que desde principios del Siglo XX y hasta la época actual, se establecieron en fuertes relaciones entre los gobiernos representativos y sus democracias. Esto devino, también, en una variada teoría en torno a éste sistema de gobierno, a su representación, a los partidos y a su fortalecimiento dentro del principio de la misma legitimidad política, ejercicio que concluyó con la representación política. 
Esta es una de las problemáticas centrales en la elaboración de las constituciones actuales y que, desde el punto de vista de este investigador, determina la desintegración del sujeto político actual porque que desconoce; sin explicación y articulación alguna, que el Estado tiene funciones en torno a una sociedad y que opera a través de elementos tradicionales cómo la exclusión, estructuración social y control, como base de toda representación política, lo expresa, acertadamente Criado de Diego (2012) cuando menciona que

La representación política ha sido durante dos siglos una categoría central del constitucionalismo a través de la cual se han pretendido explicar y sistematizar las complejas, y a menudo contradictorias, relaciones que se dan entre derecho y política, entre Estado y sociedad (...) (p. 79)

En estos estudios referentes a los partidos (sistemas de partidos, representación y democracia), la crisis de representación se denota porque los sistemas políticos deben alinearse en procesos de fortalecimiento democrático con gran participación social e incentivando la participación electoral, que es por demás conflictivo e inconstante al conjunto de reglas que imperan a los principios generales de justa convivencia, que no son otros que los de vivir honestamente, no hacerle daño a nadie y darle a cada quien lo que le corresponda, interacciones que escapan a los cambios en los partidos políticos, a los cambios en los sistemas de partidos y al cambio en la estructura de segmentación en que se basan.

Por ende, interpretando la democracia, no se puede concluir que los sistemas de partidos o de representación, sean estables porque, precisamente, para que el sistema de partidos funcione, se requiere de partidos políticos compactos y sólidos en sus principios y 
CRISIS DE REPRESENTACIÓN COMO CONSECUENCIA DEL TRANSFUGUISMO POLÍTICO EN COLOMBIA

causas fundadoras así como en una representación con personas de una altísima preparación para interrelacionarse en el campo político. Esto es manifestado por Mair (1998), al decir

(...) que si no se ha logrado establecer una directa asociación entre cambio en los partidos y cambio en los sistemas de partidos, se puede esperar que las transformaciones en las estructuras sociales y políticas tengan efectos en los sistemas de partidos por medio de los realineamientos en la ordenación de clivajes y en el modelo de competencia entre los mismos (pp 211-229),

Por lo que es sustentable que los cambios económicos, políticos y sociales de los últimos años hayan surtido algún efecto en ellos. En los estudios realizados por Alcántara (1996), se argumenta que:

Estas premisas se apoyan en estudios que se han hecho sobre los partidos y sistemas de partidos en los países de Europa Occidental y de Estados Unidos, que apuntan a que los cambios en los modelos organizativos de los partidos políticos, los altos niveles de volatilidad electoral, el descenso en los niveles de militancia, la creación artificial por parte de los partidos políticos de los conflictos sociales o el cambio de escenario en el que se desarrolla la competencia política, pueden estar generando un nuevo modelo de democracia representativa"...(...). (p.49)

De igual forma, las instituciones que suelen estar representadas, integran uno de los ejes centrales y esenciales de cualquier democracia, por ser las que promueven mecanismos de 
CRISIS DE REPRESENTACIÓN COMO CONSECUENCIA DEL TRANSFUGUISMO POLÍTICO EN COLOMBIA

"participación ciudadana", para delegar en sus representantes algunas decisiones. Esos representantes se encuentran involucrados en los partidos políticos, que a su vez forman parte de la democracia, originaria del griego

“démokratia, que en sus orígenes no se refería a una base para la legitimidad ni a un régimen que se definiera por sus buenas intenciones o por su noble misión sino simplemente a una forma de gobierno específica; una forma que, durante la mayor parte de sus 2000 años de historia, demostró ser extremadamente ilegítima en la teoría e igualmente desastrosa en su práctica (...)”, Dunn. (2014)

La representación política actual soporta un proceso de des-agrupación debido a que se insertó el cumplimiento de funciones y/o formulaciones que, inicialmente, no estaban contempladas y esto ha originado discusiones y enemistades entre quienes conforman los partidos, éstas incrementan la desconfianza de sus seguidores, dependiendo de quién o quiénes lo representan y de la perspectiva programática que proponen para dirigir.

En la actualidad parece que olvidan que, en el sistema democrático, los partidos políticos son entidades cuyo propósito principal es buscar y lograr tener el poder político, bajo una significativa representación en los diferentes órganos del Poder Público consolidado, especialmente, en el Parlamento.

Las investigaciones del sistema de partidos y de los partidos políticos se encierran en un debate alrededor de la crisis que los afecta. Por un lado, se argumenta que están sumidos en una profunda decadencia y, desde esta perspectiva, se discute la conveniencia de la existencia de las instituciones de los partidos y el rol que ellos desempeñan en la sociedad. De igual

\footnotetext{
${ }^{1}$ La participación ciudadana es llamada también democracia directa de acuerdo a lo afirmado en dicho documento" Salamanca. (2014).
} 
forma se sustenta la deslegitimación del sistema político y como ésta ha aumentado la descomposición social, porque al perderse toda aplicabilidad de las causas que aglutinan el pensamiento político de la colectividad, aflora el desconcierto y se avizora la anarquía que destruye y acaba con la pacífica convivencia de los pueblos.

Del otro lado, se tiene en cuenta la vigencia electoral de los partidos tradicionales y la capacidad que tienen de adaptación ante las transformaciones en la perspectiva institucional y al nacimiento de nuevas fuerzas políticas. Así, sus dirigentes, desarrollan más ejercicios de mecánica electoral que compromisos en favor de sus causas y doctrinas, situación que se traduce en la pérdida de identidad entre quienes son de un partido o de otro, refiriéndose a aquellos como un grupo de privilegiados que unidos gobiernan para sus propios intereses y de quienes se apoyan, no por lo que proponen sino por lo que reparten, generando así un mercado electoral, de cuánto vale su voto, que obviamente lo libera de toda responsabilidad de representación de ideales y dogmas al salir elegido.

En el análisis de la situación planteada en el presente estudio, se pueden identificar varias explicaciones dimensionales y causales a la crisis de representación que tratamos de explicar de manera antropológica y sociológica, Kerz \& Pomposo, (2006), han identificado entre otras causas, el individualismo generado por la globalización, la inadecuación de las instituciones a las necesidades de la sociedad moderna y, finalmente, la política que abarca factores como la deficiente comunicación e información de los representantes, su débil actividad hacia el querer de las demandas sociales y la crisis de la oferta política y del sistema de partidos.

La crisis de representación cobra su gran importancia a partir del estudio de los partidos políticos, porque la representación es producto de una relación, en la cual el electorado escoge y autoriza a su representante para que logre la aplicación eficaz de sus 
ideales políticos, económicos, culturales y sociales en general, para la convivencia de los asociados estableciendo, entonces, relaciones de responsabilidad totalmente claras a quienes asuman su representación y ejerciéndola de forma transparente y con la autoridad depositada en él.

Sin embargo se pone en fragilidad la condición de rendición de cuentas entre el representante y los representados, cuando las listas electorales son diseñadas por los partidos políticos; cuya complejidad aumenta, si además de lo anterior, los representantes renuncian a las estructuras por las cuales lograron ser electos, lo que permite el surgimiento del fenómeno del “transfuguismo político”, el cual se trata en el segundo capítulo.

Este fenómeno se vislumbrará a partir de una descripción del sistema actual y del comportamiento de los sistemas de partidos en la democracia colombiana, así mismo se realizará una descripción general en comparación con Chile y México, (países Latinoamericanos que comparten situaciones de hecho social similares a las Colombianas, como se demostrará en el desarrollo del presente estudio), donde también se evidencia la deslegitimación y falta de confianza de la sociedad civil hacia los partidos políticos y, hasta dónde, las organizaciones civiles, logran mayor efectividad y participación electoral debido a que, la pérdida de representación, le da mayor cabida a movimientos sociales que logran el acceso al poder como nuevos actores de la representación adquiriendo un perfil significativo en la colectividad de cada país.

Manin, (1998), reconoce entre otros aspectos, que al estar ubicados en Latinoamérica, se reconocen los diferentes sistemas políticos que operan, y esto conlleva a considerar la polarización y competencias de los sistemas de los partidos Latinoamericanos que remiten, inmediatamente, al marco jurídico de las constituciones donde la democracia representativa resulta de las diversas teorías que surgieron como resultado de las revoluciones; inglesa, 
francesa y norteamericana que, definitivamente influenciaron conjuntamente y de forma heterogénea, la creación de varias instituciones que fueron constituidas como consecuencia de las experiencias vividas en su momento.

En ellas se encuentra la teoría clásica de la representación como fuente de legitimidad del gobierno político para ejercer la autoridad pública de manera ventajosa a través de cinco necesidades centrales, de acuerdo a lo referenciado por Godoy $(2001)^{2}$, a saber:

A.- designar representantes que remplacen al pueblo y que sean mejores que aquél; B.atender al bien general y no intereses particulares; C.- deliberación racional; D.neutralización de las pasiones y E.- libertad de mandatos, los cuales complementan los cinco argumentos centrales de la teoría clásica de la representación política. (pp.18-68)

Las formas de representación dependen de diversas variables, muchas de ellas relativas al vínculo que se establece entre el representante y sus representados, siendo la variable más importante, el grado de independencia del que dispone el representante en el ejercicio de sus funciones. Un representante en un sistema democrático; en aras de la etimología de la palabra, debe ser en algún grado dependiente de los ciudadanos; es decir, de sus representados porque, si bien en una democracia representativa las leyes pueden diferir parcial y temporalmente de las preferencias particulares de los ciudadanos, no pueden; sin embargo, oponerse a ellas sistemática y frontalmente, cuando convergen dichos intereses con el bien común de todos los asociados.

\footnotetext{
2 (Godoy O, 2001). Revista de Ciencia Política , XXI (2), 18-68. Le da un tratamiento a ésta información y la clasifica de forma equivalente en su artículo "Representación y Democracia".
} 
Como fundamento de la problemática estudiada, se estableció como problema jurídico a desarrollar el siguiente interrogante: ¿Cómo la representación de los partidos políticos se afecta con el incremento del transfuguismo político?, respuesta que esperamos pueda servir como punto de futuro debate, con quien tenga la oportunidad de leer la presente tesis que se elabora con el fin de cumplir con el último requisito para lograr el título de Magister.

Para responder la pregunta de investigación se formuló la siguiente Hipótesis en esta investigación: "Se observa un aumento en las prácticas de los militantes al interior de los partidos que los lleva a abandonar la corporación para pertenecer a otros partidos, motivados por los intereses particulares del momento, debilitando al partido político y el sistema de partidos , y generando también graves consecuencias en el electorado que pierde credibilidad y confianza en las corporaciones representativas, debilitando la calidad de la representación política en el país.”

Como objetivo general de la disertación que actualmente concentra el esfuerzo de este trabajo, analizar las causas y los efectos del "transfuguismo político" como hecho generador de la crisis de la representación y de la deslegitimación de los partidos políticos en Colombia; y como objetivos específicos se establecen: I) identificar las características de la representación política y los factores generadores de la crisis actual; II) determinar cómo la crisis actual de la representación política afecta el sistema de partidos y la confianza electoral y III) establecer los mecanismos normativos y sociales a través de los cuales se puede restablecer prácticas en la calidad de la representación de la sociedad en las instituciones políticas para que se evite el transfuguismo político.

El trabajo se desarrolla en tres capítulos; el primero habla de las caracteristicas de la representacion politica y su relación con el sistema de partidos, aquí se contempla una revisión de la teoría política que, con la lectura continuada del presente estudio, se relaciona 
con el eje central del estudio que se emprende y que comienza con un somero desarrollo cronológico, aunado a los diversos conceptos y estudios sobre los partidos políticos, sus sistemas y los cambios que se han suscitado en el devenir histórico. De igual forma en este capítulo se analizará la crisis que se ha causado por la deslegitimación, como por la evolución y el estado actual de la democracia.

El capítulo segundo titulado el trasfuguismo político y sus consecuencias en la representación de los partidos políticos, analiza el gran problema de la identidad política y la pertenencia programática y dogmática de los militantes de los partidos. Este fenómeno se identifica con el título ya mencionado de transfuguismo político y cada día se hace más visible en el país. Siendo éste el tema central de ésta investigación, y consecuencia de la crisis de la representación, se hace pertinente a analizar las razones que lo motivan.

Este aspecto es contemplado desde una perspectiva teórica a la par del estudio del marco normativo vigente, y en conjunto con los actos legislativos que lo consagran. Se aborda el tema desde su mismo concepto e implementación como consecuencia de varios cambios políticos, de las marcadas secuelas históricas sobre las diferentes teorías de representación política y desde las formas de acción resultantes sobre la misma concepción de los partidos políticos y sus diversos sistemas y sus complejas formas evolutivas.

La complejidad de estos aspectos radica en que, en lugar de detener los cambios sufridos por las mismas democracias, acrecientan las crisis de representación cada vez con menos legitimidad y trayendo, como corolario, procesos negativos como el citado transfuguismo político y la creación de nuevos partidos y movimientos sin un sistema definido en la estructura y en cuanto a sus doctrinas y causas que los regulan.

En esto se denota en el afán por mantener un protagonismo personal, que conduce, invariablemente, a un sistema plutocrático, convirtiendo la actividad de las ideas políticas en 
una vulgar compra de votos o, definitivamente, en un distancia entre la población civil y el estado conocida como abstencionismo que provoca resultados nocivos como el de perderse definitivamente el concepto del bien común de los ciudadanos.

Se genera así poco interés por los asuntos políticos y se crean ambientes de desconfianza por parte del pueblo, incredulidad hacia las autoridades, a sus dirigentes y a los partidos políticos, así como hacia todos aquellos que pretenden cargos populares. Todo esto agrava la crisis del sistema de partidos, problemática inmersa en un círculo vicioso, que se expresa el debilitamiento o disminución del interés público sobre la representación política expresada en los partidos políticos, consecuencias aprovechadas por los que son responsables de tan lamentable falta de verdadera representación y que van en beneficio de sus propios intereses: actividad conocida como corrupción.

Esta se ha tratado de detener a través de normas como la ley de bancadas o de la doble militancia, cuyo estudio nos lleva igualmente a determinar, cómo hasta la fecha, que la normatividad establecida no ha logrado encontrar el camino que permita recobrar la legitimidad en la representación y, sobre todo, la credibilidad en los partidos políticos y especialmente en sus dirigentes.

El tercer capítulo, desarrolla el propósito de generar propuestas que, en virtud del marco normativo actual, logren combatir o mitigar el fenómeno del trasfuguismo. Por otra parte hace un análisis del empoderamiento de los grupos de presión, o movimientos sociales, como respuesta a la falta de credibilidad y representación de los partidos políticos y como una más de las múltiples consecuencias de la debilidad de los partidos políticos, a pesar de que, como se demuestra en el desarrollo del capítulo, éstos grupos sociales no han sido ajenos a la actual crisis de representación e incorporación de intereses mostrando, igualmente, su 
incapacidad o real falta de voluntad para articular intereses sociales y liderar diferentes sectores en una agenda social común.

\section{Capítulo I. Caracteristicas de la representacion politica y su relacion con el}

\section{sistema de partidos.}

El presente capítulo contempla una revisión de la teoría política que se encadena con el eje central del estudio que emprendemos y que comienza con un somero desarrollo cronológico aunado a los diversos conceptos y estudios sobre los partidos políticos, sus sistemas y los cambios que se han suscitado en el devenir histórico. Así mismo en este capítulo se analiza la crisis que se ha causado por la deslegitimación, como por la evolución y el estado actual de la democracia.

\subsection{Perspectivas teóricas y evolución de la Representación Política}

Heller (1963) explica que el concepto sobre representación es fundamental para la cimentación jurídica de los Estados, al ser ésta, en un instrumento que permite la disminución de la pluralidad social y la transformación de ésta en la unidad de acción y decisión del Estado ${ }^{3}$.

Es así, que toda teoría sobre la representación debe brindar un punto de equilibrio entre los diversos valores y principios en juego teniendo en cuenta que, este balance entre dependencia e independencia, sólo se puede brindar con una teoría normativa de la representación, como lo sostiene Rey Salamanca $(2014)^{4}$ cuando dice: “(...)el concepto de

\footnotetext{
${ }^{3}$ Ocurre que la formulación de la teoría jurídica del Estado y además que se cifre en las consideraciones igualmente del Estado como ente organizado, o sea, sujeto de derechos y deberes que funcione conforme a la sistematización por medio de sus órganos, se engendra en un contexto histórico en que la extensión representativa del Estado, interviene la relación entre aparato político y sociedad.
} 
representación, sin embargo, para los teóricos no es unánime, por más de dos siglos se vienen enfrentando diversas concepciones teóricas, sin un resultado exacto al respecto" (p. 146).

Sus primeros debates comenzaron al tratar de determinar si la representación era un mandato libre o un mandato imperativo, y al respecto Weber (1964), distinguió cinco tipos de representación con diferentes grados de independencia: I) la representación apropiada; II) la representación estamental; III) la representación vinculada; IV) la representación libre y V) la representación de intereses (pp 235-237), de las cuales, prácticamente, todos los regímenes políticos han reconocido dos de ellas: la representación libre y la representación vinculada, que se encuentran inmersas en los mandatos libres o imperativos.

La división se concentró entre quienes pensaban que los representantes no debían estar atados a la voluntad de sus electores y entre quienes consideraban que los electores si deberían poder instruir u ordenar algo a sus representantes.

De acuerdo con Rehfeld Andrew, citado por Salamanca $(2014)^{4}$, los orígenes del mandato imperativo comenzaron en Inglaterra en el S. XIII, cuando los representantes de los pueblos y ciudades recibían órdenes de sus conciudadanos acerca de no aceptar el cobro de impuestos por parte del rey y por tanto negarse a su recaudo. Igualmente en España la representación en los reinos, mezclaba formas de mandato imperativo y mandato libre, la Ley se impartía en Cortes, en encuentros del rey con varios estamentos o brazos, (según fuera el caso) brazo eclesiástico, la nobleza y las gentes de las ciudades, etc.,

Éstas últimas acudían a las Cortes a través de representantes (síndicos), que debían estar autorizados por medio de un poder que les otorgaban los habitantes del lugar por elección general. Así, los mandatos imperativo y libre se mezclaban, los representantes

\footnotetext{
${ }^{4}$ Ya para los años 60 Pitkin (1967), indicaba sobre "la controversia clave y clásica en la literatura sobre la representación política"
} 
recibían instrucciones ${ }^{5}$ de los miembros de sus municipios, pero a la vez eran libres para buscar en las Cortes la mejor manera de cumplirlas, como la utilización de mecanismos legales para que los representantes pudieran deliberar. En España, estos mandatos fueron vigentes poco antes del Siglo XIX.

En Francia, el mandato imperativo jugó un doble papel, fue utilizado en la administración de las ciudades y para las reuniones de los estamentos con el rey como en España. Así como lo argumentó Tocqueville (1969), en el siglo XVIII el gobierno de casi todas las ciudades francesas estuvo a cargo de dos asambleas, la primera se conocía como el cuerpo de la villa y ejercía el poder ejecutivo y la segunda era la asamblea general la cual comenzó en el siglo XI como órgano popular. El pueblo elegía a sus oficiales y estos debían consultarle y rendirle cuentas. A comienzos del siglo XVIII las asambleas pierden toda conexión con el pueblo. Sus miembros pasaron a ser "notables" y concurrían por algún derecho propio que previamente habían adquirido por posición o como delegados de las corporaciones profesionales vinculados a estas por mandato imperativo.

Igualmente, en Francia, el mandato imperativo se utilizó para instruir a quienes debían representar a los estados generales ante el rey. Cada pueblo, o ciudad, reunido en una asamblea primaria elaboraba un cahier $^{6}$ con las peticiones del municipio. Luego las asambleas elegían representantes para que concurrieran a la elaboración de los cahiers generales.

Tocqueville (1969), recuerda que ese tipo de mandato imperativo no sobrevivió a la revolución francesa y que la Constitución de 1791, prohibió estrictamente cualquier forma de mandato imperativo puesto que había nacido un nuevo gobierno de representantes que se habían autoproclamado "libres" (p. 77), Así los franceses partieron la historia de la

\footnotetext{
${ }^{5}$ Las instrucciones iban acompañadas de algún grado de discrecionalidad para que los representantes pudieran deliberar y tomar las decisiones con un margen de libertad

${ }^{6}$ Los cahier era el método empleado para dar las instrucciones "cuaderno de instrucciones" o cahiers de doléances
} 
representación en dos. estableciendo un sistema político asambleario que usualmente suprimía las relaciones entre ciudadanos y sus representantes.

Salamanca (2014) explica que "El mandato era libre porque ni las asambleas primarias ni las secundarias podían disponer nada en particular sobre el contenido de la legislación, y sólo podían elegir a los miembros de la asamblea nacional” (p. 48).

Por otro lado, el mandato imperativo tuvo su auge en Norteamérica según lo argumenta Manin, (1998), él plantea que originalmente, en la época de la colonia, y posteriormente, en la de la independencia, apareció en las constituciones de algunos estados el derecho de dar instrucciones a los representantes; pero el primer congreso de Estados Unidos decidió no incluir este derecho en el "Bill of Rights" 7 , que algunos miembros del congreso habían propuesto que fuera parte de la Primera Enmienda sobre la libertad de expresión.

Siguiendo el contexto evolutivo histórico de la representación, llegamos a la teoría política en el instante en que el Estado se convierte en una forma política de concentración del poder con un soporte rigurosamente social. La representación es el elemento que tolera una fórmula unitaria y genérica del Estado ya que permite relacionar la concentración y la centralización del poder en él mismo con las tipologías de un grupo humano cuya sumisión y acatamiento al poder, que tiene el Estado, reclama y justifica su representación concentrada en una formalización jurídica.

Así es que Criado de Diego, (2012) indica que es la función de la "raepresentatio assortiva" que se establece en el "Leviatán" de Thomas Hobbes, arguye que el desarrollo de la teoría de la representación está estrechamente ligada al nacimiento del Estado en la edad moderna y su consolidación en el mundo contemporáneo; sin embargo, resultó paradójico,

\footnotetext{
${ }^{7}$ Bill of Rights"” Carta de derechos o Declaración de derechos.
} 
promulgar el soporte social del Estado para luego fundamentarlo como una sociedad estática y funcional a la necesaria unidad del Estado.

Esa contradicción permitió ver en el Estado una institución de dominio político que permitió que una parte de las ciencias sociales y políticas renunciaran a seguir la doctrina del Estado, respecto a los principios del Estado de derecho y de la soberanía popular, dando aplicación a lo manifestado por Heller (1963) de reemplazar las determinaciones abstractas de las instituciones por su significado objetivo, haciendo así de la doctrina del Estado, una “ciencia de la realidad", En efecto el autor dijo: "La unidad política del cuerpo social entendida como voluntad que, careciendo de existencia empírica, sólo puede ser representada" $^{\prime 8}$ (p. 175) . Es decir, la autoridad deriva del Estado por medio de leyes, como quedó redactado en el "Leviatán" en su capítulo XXII, indicando que el poder del representante está siempre limitado por el poder del Estado como ente soberano; agregando que si el representante procede por fuera de las leyes, se está representando a sí mismo y sus actos son propios, y si funciona dentro de las leyes, sus actos son del soberano y todos los coasociados son los autores.

"La separación que hace Hobbes del Estado de su hipotético momento fundacional a través de un pacto, hace que este funcione como una mera descripción del origen del Estado, pero no como un elemento explicativo del ser del Estado, por lo que la existencia real del Estado no debe ser considerada por referencia a las personas reales que lo forman" (Criado de Diego 2012, p. 85).

Lo anterior nos indica que el concepto de representación expresa el tipo de relación que existe entre el tomador del poder público y los sometidos a él. Es un concepto dinámico de 
representación que considera las formas de estructuración entre el poder y la sociedad. El surgimiento del Estado y su progreso en la democracia constitucional, suponen una reconfiguración jurídica y real de las formas de articulación que funciona con concepciones y se cimenta en instituciones que tienen algún significado histórico. Las formas de organización y comunicación entre sociedad y Estado se sistematizan mediante el fraccionamiento entre la representación de cara al poder y la propia representación en el poder.

Cuando la representación se encuentra de cara al poder, se convierte en el contrario lógico de la representación estática. Si el poder es representación abstracta de la sociedad en su unidad, tendrá que existir un mecanismo de expresión real de la sociedad en su fragmentación. Así mismo, Criado de Diego (2012) sostiene que:

"Si el Estado es organización política de la totalidad social, será porque existen organizaciones parciales capaces de darse a conocer en su multiplicidad. La representación frente al poder remite por tanto a la idea de "instituciones representativas", de comunicación entre sociedad y poder, y es la función que, en el esquema absolutista, Hobbes reserva a los cuerpos intermedios (sistema subordinata), incapaces de emitir una voluntad política dotada de autoridad, pues esto corresponde en exclusiva al soberano, pero capaces de representarse a sí mismos. La idea de representación frente al poder presupone la existencia de dos aspectos del fenómeno estatal: el Estado-aparato o Estado-sujeto, es decir la autoridad, y el Estado-comunidad, entendido como el conjunto de los sometidos a la autoridad. La representación lo es de la comunidad frente al aparato, de la estructuración social frente a la organización política” (p. 88). 
Es decir; el modelo francés desarrolla una construcción doctrinal y dogmática de la unidad política del Estado y del gobierno mientras que, en el inglés y norteamericano, el efecto provendrá de la praxis de la pugna institucional por la gestión del Estado coronaparlamento en el caso inglés, y federación-Estados en el caso norteamericano.

Por otra parte, la teoría de la representación política está esencialmente definida sobre la base de tres fundamentos conceptuales. La del individuo elector, la de la propiedad privada y la división del trabajo.

Noria (1999), manifiesta que "el individuo elector representa la expresión de la historia filosófica y política que emerge en el interior del proceso, concibiendo la idea del sufragio, desde el origen, como un acto simple de elección dentro de una sociedad dividida en mandatos privilegiados y cuerpos intermediarios, caracterizándose la elección por recaer sobre la representación institucional y no sobre el individuo en el sentido político moderno de este concepto". (pp. 18 -25).

Respecto a la propiedad privada Noria (1999), indica que "se volvió la piedra angular de la nueva legislación liberal elaborado por el abate ${ }^{9}$ sobre la emergencia del individualismo económico y jurídico del nuevo orden de una república industriosa”. Concepto éste utilizado por el abate para definir a la república francesa como una nación basada en el principio de la división del trabajo, el trabajo industrioso, la seguridad y la felicidad de sus habitantes (...) (p. 20).

La división del trabajo abarca toda la sociedad civil, lugar o espacio público ${ }^{10}$ en el que se desarrollaba la ciudadanía como un colectivo plural o individuo activo de la sociedad

\footnotetext{
${ }^{9}$ El abate es utilizado referenciando al clérigo o iglesia.

10 Sieyés citado por Noria (1999), expone la idea de socialización de la opinión pública como la prensa, y le da significado al espacio público como a las discusiones presentadas en el seno de la Asamblea Nacional.
} 
CRISIS DE REPRESENTACIÓN COMO CONSECUENCIA DEL TRANSFUGUISMO POLÍTICO EN COLOMBIA

comercial. De acuerdo con Sieyés citado por Noria (1999) en este espacio coinciden la división del trabajo y la representación política.

Noria (1999), reconoce que la idea de la libertad moderna se apoya en el sistema representativo que descansa en la figura del ciudadano elector, los ciudadanos delegan en sus representantes la defensa y cuidado de sus intereses y esta delegación es una característica de la libertad moderna.

Sieyés, Condorcet y Guizot citados por Noria (1999), como los teóricos más destacados en la última corriente filosófica del tema, basan sus argumentos en que la naturaleza del gobierno más apropiado debía elaborarse sobre el plan constitucional conformado por dos posiciones totalmente opuestas, la primera era la democracia pura, sustentada por los ultra demócratas y la segunda que constituía el sistema representativo, indicando además que la Nación soberana y única, debe ejercer el gobierno sólo mediante una delegación del poder, insistencia de Sieyés en que la Nación sólo delegue un poder limitado, justo el necesario para ejercer el gobierno por procuración, estableciéndose así los aspectos que forman la diferencia entre la democracia directa y la forma representativa de gobierno (p. 147).

Para el Sieyés (citado por Noria, 1999), la representación no podía ser descriptiva; es decir, no podía reflejar nada que ya existiera, por el contrario creaba la voluntad general del Estado, siendo interpretativa de los intereses ciudadanos.

“El representante no pone en escena las preferencias de sus comitentes ni se instruye con ellas, no recibe ni cumple mandatos; en vez de eso procesa las 
preferencias de los ciudadanos por medio de su propio criterio y de la deliberación para contribuir a la formación de una voluntad común” (Maíz, 2007).

La parte crucial para Mansbridge (2003), está en que la deliberación debe estar más ubicada entre representantes y electores, los medios de comunicación y otros grupos de presión. Éste autor argumenta que la independencia promueve también un mejor intercambio de opiniones y posturas entre ciudadanos y representantes.

En las afirmaciones anteriores, se va vislumbrando la aparición de gobiernos representativos lo cual asombra por su enigmática relación con la democracia. Diversos autores, por un lado, crean la idea en la soberanía del pueblo y en la aprobación de los ciudadanos y, por otro, ante la dificultad de fundar un modelo de gobierno con la intervención directa del pueblo en las decisiones públicas, la remplazan por un sistema indirecto que establece una distancia de los ciudadanos con las instituciones políticas. “(...) distancia, que no existió en las democracias antiguas,(...) colmada por la representación. Esta ambigüedad está parcialmente salvada por la distinción entre gobierno representativo y la democracia directa" (Godoy 2001).

El fenómeno evolutivo del gobierno representativo fue anunciado por Tocqueville (1961), hasta llegar a nuestros días en que se le conoce con el nombre de democracia representativa, proceso en que se involucran tres fenómenos que imprimen la unión entre representación y democracia; la ampliacidón de los derechos y libertades del hombre; la expansión de las igualdades y la difusión del sufragio universal que, a finales del siglo XIX, consolida los argumentos que conforman la red de la teoría del gobierno representativo, cuyo antecedente teórico, fue la aprobación de los individuos como expresión del principio de soberanía popular. 
Uno de los primeros pensadores en sistemas representativos fue Montesquieu quien observó una relación entre espacio físico y régimen político como variables del sistema representativo. Este autor establece nexos entre la naturaleza y los principios de la política analizando la población desde un Estado libre, el pueblo como un cuerpo, y en asamblea, ejercería llanamente poderes políticos y, sin embargo, menciona el autor, en los grandes Estados es imposible por el tamaño de la población (Iglesias, 1984).

Por esta razón, si se quiere adoptar como premisa la soberanía popular, el pueblo “deberá realizar por medio de representantes lo que no puede hacer por sí mismo”,( Iglesias, 1984, p. 25), así emerge el representante como ejecutor de lo que el pueblo no puede realizar por sí mismo. De igual modo, Montesquieu expone que las bases del gobierno representativo sean a partir del principio de soberanía popular a través de elecciones. Igualmente lo manifiesta Manin, (1998):

“(...) Grotius, Pufendorf, Hobbes y Locke, cruzando todo el espectro de los teóricos del derecho natural moderno, hasta Rousseau y Kant, el consentimiento y la voluntad libre se constituyen en la fuente de la autoridad legítima y el fundamento de las obligaciones de los gobernados respecto de los gobernantes" (p. 211)

Contrario a la teoría de la personalidad del Estado, precisamente por no ser representativo el autor Carré del Malberg, (1998) manifiesta que:

“(...)la representación consiste en el poder objetivo de querer por la nación, en virtud de la constitución sustituido como una nueva doctrina "que ve en la representación un carácter subjetivo propio de las autoridades elegidas y proveniente 
CRISIS DE REPRESENTACIÓN COMO CONSECUENCIA DEL TRANSFUGUISMO POLÍTICO EN COLOMBIA

de las relaciones especiales que se establecen entre esas autoridades y el pueblo por el hecho de la elección" (...) (p. 1003).

De esta forma nace la idea del gobierno representativo, cuya función el gobierno la encomienda al cuerpo legislativo, así, sólo se podría hablar de representación en el Estado; contrario al sentido de participación al ejercicio del poder, es más como un mecanismo ideológico de obtención legítima. Así se forma una relación orgánica entre pueblo y parlamento, por lo que se puede afirmar que la voluntad de los representantes es fácticamente la voluntad del pueblo.

No es una relación de dos voluntades diferentes, (como la supuesta de la representación ante el poder), sino una voluntad única expresada por el parlamento, ya que pueblo y parlamento son, desde el punto de vista jurídico, una unidad. La función de la representación sería la de unificar al pueblo en el ámbito del derecho, evitando así, que los conflictos sociales entren el ámbito institucional y que; como anteriormente se dijo, se entronice en la llamada representación estática, referenciada por Criado de Diego, (2012): “fue que se sentaron las bases jurídico-dogmáticas para la consideración del parlamento como organización jurídica del pueblo, y de la voluntad del parlamento como voluntad del pueblo mismo". Esta base servirá de para la adaptación de las constituciones representativas al desarrollo de los partidos políticos.

\subsection{Evolución histórica y teórica sobre partidos políticos y su sistema en Francia y Estados Unidos.}

\subsubsection{Francia}


Francia ha contado a través de su historia con diversos partidos, algunos considerados de izquierda, (como el partido comunista denominado PCF); y otros de extrema derecha, (entre ellos el Frente Nacional (FN) antes llamados poujadistas). Uno de los partidos, de orden socialista ortodoxo llamado los gaullistas, surgió de la rama conservadora que en 1976 comenzó a llamarse PG. En el periodo de 1946 a 1958 existió el partido cristiano demócrata (PPR), del cual varios de sus miembros se retiraron para unirse en 1978 al UDF, (movimiento político que inició siendo ecologista de centro derecha, aunque con raíces liberales, porque surgió de la fusión de los partidos Centro Democrático, Republicano y del Partido Radical). (Ware, 2004).

A partir de la creación de los partidos se comenzó a dar una base ideológica; por ejemplo: el sindicalismo a comienzos del siglo XX, estaba marcado por ideologías anarcosindicalistas, luego sucedió la ruptura entre socialistas y comunistas y fueron, éstos últimos, los que incidieron fuertemente en la industria entre 1920 a 1930; pero, posterior a esa década, el partido comunista fue perdiendo su fuerza y, durante la quinta república, fue cambiando el contenido ideológico cuando agarró impulso el FN. Éste, partir de los años ochenta, dio cabida a partidos de extrema derecha que buscaban nuevas alternativas contra los gaullistas quienes, durante la Quinta República y por más de 25 años, monopolizaron la derecha del país francés.

La afiliación a los partidos no tuvo mayor influencia en Francia. En efecto, para finales de 1980 sólo el 9\% de los votantes comunistas se encontraban afiliados a su partido, entre tanto, el número de afiliados al partido socialista era cercano al 3\% y el UDF contaba con un 3\% menor que el anterior. El partido Gaullista reportó, para la misma época, un 12\% de afiliados, porcentaje considerado como exagerado en su oportunidad (porque no representaba la realidad de penetración del partido), pero estos reportes, en definitiva, no llegaron a interesar estos porque, en Francia, los partidos tenían unas funciones limitadas en la 
lucha electoral en la medida en que los partidos no son intermediarios entre los votantes y los beneficios públicos por lo que, realmente no les interesaba tener estadísticas claras sobre sus activistas, quienes, por demás, recibían escasos auxilios y beneficios materiales. (Ware, 2004)

Los partidos franceses tuvieron un desarrollo organizacional tardío, encontrando que, a finales de 1958, los comunistas estaban extendidos, teniendo, como resultado, vínculos débiles entre los partidos y los votantes, tanto que, el electorado, no identificaba al partido y por ello la reforma que se vino con la instauración de un sistema presidencial trajo como consecuencia política que los partidos de centro, de derecha y socialista, con el objeto de acaudalar membrecía, se vieran obligados a conceptuar nuevas ideas para que los votantes se vincularan a ellos.

Las campañas presidencialistas comenzaron a apoyarse con la televisión, lo que hizo crecer la necesidad de hacer campañas impulsando a los partidos hacia organizaciones centralizadas. (Actualmente, los partidos franceses siguen teniendo afiliaciones reducidas en comparación con el resto de países europeos porque, además de lo expuesto, la variación de "izquierda y de derecha en el poder, ha generado débiles presiones a favor de la cartelización" (Ware, 2004, p. 186) ) La evolución económica de Francia evidenció la disminución del campesinado y de los pequeños comerciantes, lo que generó transformaciones en el sistema de partidos; cambios que eran eventuales debido a las nuevas corporaciones políticas. El cambio en la ordenación social hizo así posible que las nuevas instituciones políticas crearan un sistema de partidos completamente diferente.

Todos esos cambios le comenzaron a dar un aire de renovación al FN, el cual, defendía las políticas de derecha. Éste tomó auge a partir de los ochenta, posicionándose con el argumento de que los conflictos sociales desaparecerían al acrecentar la prosperidad, discurso que lo llevó al éxito electoral en las elecciones del Parlamento Europeo de 1984 y que 
CRISIS DE REPRESENTACIÓN COMO CONSECUENCIA DEL TRANSFUGUISMO POLÍTICO EN COLOMBIA

los consolidó cuando se produjo el cambio del sistema proporcional por uno de dos vueltas, y por ende, causó problemas a los otros partidos (PG, UDF y PS) respecto de las estrategias electorales. Así lo que afirma Ware (2004):

"El sistema de dos vueltas supone un fuerte incentivo para que un partido establezca alianzas con otros partidos que persuaden a sus simpatizantes para que cambien su voto una vez que el partido que representaba su primera opción ha sido eliminado. Aún así, los partidos de las principales "corrientes" no querían presentarse como los beneficiarios de los votantes del FN que habían cambiado su voto, si bien tampoco deseaban que sus oponentes se beneficiaran de esta eventualidad. (...)( p. $360)$.

Francia como caso típico y cómo prodigio de la Quinta República, no cuenta con una clase administrativa que inscriba parte sustancial de la clase política, que además coadyuve a su profesionalización. “(...) los mecanismos de representación obedecen igualmente a los principios que determinan el reclutamiento del personal político (...) y se constata que existe una similitud bastante estrecha entre el reclutamiento social de los partidos y sus zonas de fuerza en el espacio social" (Gaxie, 1992, p. 40).

Converse \& Pierce (1986), plantean que "el sistema representativo francés cuenta con una capacidad de respuesta oportuna a las demandas de la sociedad que están centradas en el partido político como ente colectivo central, capaces de dictar proyectos políticos que consigan apoyo en la legislatura y con normas estrictas de disciplina partidaria" (p. 780).

Para Francia funciona el sistema semipresidencialista, el cual ha permitido legitimidad y permanencia a la democracia. La experiencia del entendimiento entre partidos, 
CRISIS DE REPRESENTACIÓN COMO CONSECUENCIA DEL TRANSFUGUISMO POLÍTICO EN COLOMBIA

(1986-1988; 1993), ha constatado que es eficaz la coexistencia de un "ejecutivo dual", con un presidente elegido por voto popular junto a un primer ministro garante y comprometido ante el parlamento.

\subsubsection{Estados Unidos}

De acuerdo a lo planteado por Ware (2004), Estados Unidos cuenta con un sistema bipartidista que en sus inicios tenían principios liberales; (aunque algunos votantes republicanos dijeran que eran conservadores, el partido Republicano no es un partido conservador). En los Estados Unidos independientes no evolucionó nada que no fuera de partidos liberales porque, los valores liberales, eran los únicos que tenían una amplia legitimidad en la sociedad. (Ware, 2004. p.104). Esto se dio, entre otras razones porque, en los Siglos XVII y XVIII, Estados Unidos se caracterizó por ser un país de emigrantes de otras poblaciones, la gran mayoría de la sociedad británica, por lo que no tuvo una base social propia y arraigada de donde le surgieran valores conservadores y es por eso que no hay antecedentes de esta línea.

El partido liberal tuvo un crecimiento ostensible debido a que no tenía contrincantes y eso le permitió instaurarse como la mayor ideología americana, incluso, durante la industrialización puesto que, el socialismo, no tuvo entrada real en la ideología americana según lo referenciado por Ikenberry (1988):

“(...)La diferencia crítica fue la ausencia de conservadurismo en los Estados Unidos. El desarrollo de las ideas socialistas sólo podía darse en sociedades en las que 
ya hubiera una tradición de ideas políticas "colectivistas". En Europa y en Canadá el colectivismo inherente a la ideología conservadora fue el semillero a partir del cual pudieron evolucionar las ideas socialistas. Sin embargo, en los Estados Unidos el completo dominio de los valores liberales impidió estos procesos” (...) (p. 222).

Los dos partidos (Republicano y Demócrata) de tendencia liberal, se separaron por las diferencias económicas y la orientación política que le daba a cada vertiente. No obstante, en Estados Unidos, los partidos no se enfrentaron a un reto fuerte por sectores socialistas lo que, al final, los favoreció porque no tuvieron que someterse a presiones para cambiar sus estructuras. La organización de los partidos americanos no tuvo que confrontar el reto deliberante que se presentaban en los partidos de bases militantes y organizadas por secciones $\mathrm{y}$, de ese modo, no tuvieron que reformar las organizaciones en ese sentido.

Los partidos Demócrata y Republicano son las dos vertientes en que se han debatido los votantes de Estados Unidos sin que haya una línea clara conservadora. Se podría señalar a los demócratas como liberales y a los Republicanos como conservadores cuando comenzaron las rupturas políticas en el año 1920 con la entrada del Laissez-faire (libre mercado), lo que incitó a la separación de partidarios demócratas que no estaban de acuerdo con la intervención del gobierno federal en cuestiones económicas y de los sectores que sí apoyaban esta corriente.

El partido republicano hace su oposición concretamente sobre la política económica del país ya que discrepa con que el Estado sea económicamente intervencionista.

“...El republicano Barry Goldwater fue el primero que en los años sesenta se autodenominó “conservador", utilizando este término en el sentido de un detractor de 
la intervención gubernamental. Pero el uso del concepto se popularizó de modo y manera que en los años setenta, los conservadores americanos que decían tener un estilo propio en realidad se adherían al tipo de filosofía económica que habían defendido los liberales europeos... En contra del punto de vista tradicional de los conservadores europeos, los "conservadores" norteamericanos defendían un mercado libre sin restricción alguna" (Ware, 2004, p. 60).

Los partidos Demócrata y Republicano no son partidos de masas por lo que no cuentan con un sistema de afiliación formal a ellos haciendo difícil sus mediciones en comparación con el resto del mundo. Pero podemos decir que la 'edad de oro' de los partidos políticos fue desde el año 1830 hasta el año 1890, época en la que se amplió el número de cargos electivos y hubo un gran incremento en el tamaño del electorado dado que se canalizó el activismo a través de los partidos y no de los candidatos independientes. Del mismo modo se acrecentó, sustancialmente, el electorado surgiendo un sistema bipartidista bastante competitivo que logró movilizarlo.

Así, como lo indica Ware, (2004), para esa movilización se requería tener a disposición gran cantidad de activistas confiables que llevaran a cabo tareas específicas en periodos electorales; allí, cobraron gran importancia los incentivos solidarios para el logro de la incorporación de nuevos partidarios. En la medida en que se supo cómo reunir al electorado en forma masiva, le hicieron enfrentarse, con serena paz política, al reto del nuevo siglo emprendido en la década de 1890 y años subsiguientes tal y como sucedió en diferentes países donde, los partidos burgueses, se enfrentaron al cambio como respuesta a la postura de los partidos socialistas para reclutar a sus seguidores. 
Desde 1960, la ayuda de la televisión permitió que los candidatos se presentasen a elecciones sin la ayuda del partido y esto contribuyó a debilitar, mayormente, el sistema de partidos al establecerse una ruptura en el equilibrio con sus candidatos, brindándole a estos la mejor parte. A este respecto Ware (2004) destaca como “(...) las campañas organizadas por los candidatos y los grupos unidos en torno a una causa fueran ganando en capacidad de atracción”, (p. 153). De este modo es posible afirmar que en este cambio ocupó un gran lugar la tecnología, (en especial la televisión), que facilitó la labor de los candidatos.

A mediados de siglo pasado, comenzaron a organizarse en camarillas de notables acrecentando centros de poder que minaron completamente las prácticas democráticas de los partidos, conllevando a una política de patronazgo, como menciona Ware (2004): "una política llevada a cabo por maquinarias políticas de base clientelar que funcionaba sobre todo, aunque no exclusivamente, en áreas urbanas". (p. 153).

Más adelante formaron un sistema de influencias de partido muy descentralizado el cual generó gran poder a nivel metropolitano, aunque el partido a nivel nacional se debilitara. Ese modelo político centrado en los candidatos se acopla correctamente con el Partido Republicano, sus organizaciones de asociación han conservado mucha más vitalidad que las de los demócratas.

De los primeros signos fundamentales que se dieron para el cambio en la relación entre partidos y votantes, fue el incremento del número de personas que se consideraban independientes en vez de demócratas o republicanos: de un 10\% pasaron a un 30\%. El adelanto característico del sistema de partidos de Estados Unidos no englobaba el incremento de los independientes como una variante en la relación entre identificación con un partido y comportamiento electoral. Así, los votantes se identificaran con un partido u otro, estaban cada 
CRISIS DE REPRESENTACIÓN COMO CONSECUENCIA DEL TRANSFUGUISMO POLÍTICO EN COLOMBIA

vez más dispuestos a cambiar su apoyo y su voto de acuerdo a sus propias creencias y conveniencias, lo cual, se evidenció en varias elecciones realizadas después de 1960 donde se eligieron presidentes republicanos y, al mismo tiempo en la Cámara de Representantes, una contundente mayoría demócrata tal y como se vio en las elecciones de 1968, 1972, 1980, 1984 y 1988.

El debilitamiento del vínculo entre partidos y líderes dio lugar a un modelo distinto generando reformas sustanciales en los sistemas de partidos. No existe otro país que tenga vuelcos tan prominentes de aproximadamente cada 30 años como Norteamérica, y esto "es el resultado de la tensión entre un sistema económico altamente desarrollado y un sistema político subdesarrollado” (Burnham, 1982. p. 93 ), así es que cuando se cambia el voto en elecciones, se genera un reordenamiento del sistema de partidos.

\subsection{Representación política, democracia y gobiernos representativos.}

Los partidos políticos son organizaciones que tienen como fin último llegar al poder político dentro de un sistema representativo; es decir, se crearon para garantizar la competición de las instituciones hacia el poder por medio del parlamento y tomando una representación democrática. Así es que, hay una dependencia directa entre partidos políticos y representación democrática porque en esto los partidos políticos materializan el proceso que da como resultado la representación, un mecanismo que nace para la deliberación pública y para que lo que el gobierno decidiera se tradujera hacia el pueblo por sus representantes.

La palabra representación viene del latín representatio que según el diccionario de la Real Academia Española (R.A.E) significa en una de sus acepciones; “(...) hacer presente, 
CRISIS DE REPRESENTACIÓN COMO CONSECUENCIA DEL TRANSFUGUISMO POLÍTICO EN COLOMBIA

manifestar o presentar de nuevo" y como lo referencia Abal (2004), Hobbes conceptuó "la persona es el actor, y quién es dueño de sus palabras y acciones es el autor (...)” (p. 40), lo que constituye que la representación es hablar y actuar a nombre de otros.

De igual forma, en el campo político Burke (1774), afirma que el representante tiene como papel principal propender por el interés general y no por intereses individuales o específicos de algunas colectividades o pocas personas debido a que, su papel, no es de emisario; sino de representante del pueblo, precisamente porque, cuando se incrementa el número de habitantes, es poco probable reunir todas las voluntades de la comunidad para lograr recoger un voto general. Por ello se instauró la designación de un representante que pudiera llevar un sólo voto que interpretara la decisión de la voluntad de muchos ciudadanos, brindándole autonomía en la toma de decisiones en aras del interés común. (Pantoja, 1993)

En resumen, la representación política es el mecanismo por medio del cual el pueblo selecciona y elige a alguno de sus integrantes para que defiendan temas e intereses generales de la comunidad, de ese modo, la comunidad lo elige como su representante y lo ubica en una parte donde se toman decisiones de gobierno.

En una democracia representativa, el pueblo o la nación cede a la representante el papel de argumentar, desarrollar, defender y difundir sus intereses y objetivos. La nación también le delega la capacidad de decidir sobre los asuntos públicos y su autoridad. El representante, para serlo, debe demostrar que es el más capacitado y competente para defenderlos por sobre otros miembros que también desean alcanzar la misma representatividad o, por lo menos convencer a la comunidad para que lo elija como tal; de esta forma la representación tiene un “valor selectivo”.(Rosales \& Rojas, 2012).

Por consiguiente, la representación política es un estado que adquiere una persona para representar a muchas otras, debido a que los representados otorgan por medio de su voto, 
poder a la persona o representante que interviene en nombre de otros y lo hace a nombre del interés de quienes lo eligieron. La anterior afirmación es debatible, ya que se puede estimar que los representantes no representan el interés de todos los representados; sino sólo los del sector o grupo que los llevó al poder.

Una de las maneras para planear 1a representación es la colectiva, (manifiesta en los partidos políticos), por lo que se necesita del establecimiento de normas para reglamentarlos, por eso, no es posible que exista la representación sin la existencia de los partidos políticos.

Así como lo indicó Sartori (2002), cuando los partidos políticos ingresan se complica los razonamientos de la teoría de la representación. Igualmente James Bryce, citado por Montero y Gunther (2004), afirma que "los partidos son inevitables: no ha existido ningún país libre sin ellos; y nadie ha mostrado cómo podría funcionar el gobierno representativo sin ellos" (p. 307), lo que significa que la representación se puede concebir teóricamente, sin los partidos políticos, además que los representantes electos procedentes de partidos tienen dos lealtades, los votantes y los partidos. De igual manera Sartori (2002) sustenta que "la legitimidad democrática afirma que el poder deriva del demos, del pueblo, es decir, se basa sobre el consenso verificado (no presunto) de los ciudadanos" (p. 30).

Sartori (2005) indica que la democracia no solo tiene la connotación que le dan los vocablos, (kratos: poder - demos: del pueblo); sino que muestra que en los sistemas democráticos no termina de desarrollarse la democracia generando, más bien, 'poliarquías', aunque se deban llamar democráticos por la normatividad de los mismos, por eso, Sartori mantiene como premisa fundamental que la democracia es el poder del pueblo.

Para este autor, la democracia se inserta en un marco único donde está la democracia social, la cual consiste en la igualdad de condiciones, existe un espíritu igualitario que se refleja en la inexistencia de estamentos sociales y la democracia económica que es entendida 
como la introducción de la democracia en el mundo laboral: en la organización y gestión del trabajo; pero puntualiza, enfáticamente, que sin el marco político democrático, que es en esencia la democracia, no puede haber ni democracia social ni democracia económica.

Profundizando un poco más sobre la democracia, ésta se remonta a épocas antes de Cristo y, hasta la actualidad, ha sufrido varias transformaciones. Aristóteles clasificó la democracia como las formas malas de gobierno llegando a ser un término negativo en los gobiernos. Por su parte Kant, en 1795, indicó que la democracia es necesariamente un despotismo.

Ya a mitad del siglo XIX, la palabra democracia obtiene una significación mejor y elogiosa, dice Sartori (2002), cuando se desarrolla la teoría y construye la democracia como principio de legitimidad. Históricamente, la democracia se clasifica de acuerdo a las formas de gobierno construidas, (tanto por Platón y luego por Aristóteles), en tres tipos básicos: monarquía (gobierno de uno), aristocracia (gobierno de pocos), democracia (gobierno de la multitud).

Como lo señala Alcántara (1997), la forma de gobierno, según la democracia es el gobierno del pueblo, de todos los ciudadanos, o bien, de todos aquellos que gozan de los derechos de ciudadanía.

Entonces, la democracia se entiende como el sistema de gobierno, donde todos y cada uno de los ciudadanos, que tienen igualdad de derechos, participan en los debates, lineamientos y aplicaciones de cuanto les compete en lo político, económico y social. La democracia constituye un estilo de vida basado en el respeto a la dignidad humana, la libertad, la igualdad y los derechos de todos y de cada uno de los miembros de la sociedad. 
La democracia en el libre juego de las mayorías y minorías, requiere opinión pública con libertad para formar partidos políticos y tener la oportunidad, aun en minoría, de influir en la formación de la voluntad mayoritaria y así mayor libertad en la aplicación de las reglas de juego.

Las formas de practicar la democracia son:

- La democracia directa, cuando la decisión es adoptada directamente por los miembros del pueblo.

- La democracia indirecta o representativa, cuando la decisión es adoptada por personas reconocidas por el pueblo como sus representantes.

- Por último, la democracia participativa, cuando se aplica un modelo político que facilita a los ciudadanos su capacidad de asociarse y organizarse de tal modo que puedan ejercer una influencia directa en las decisiones públicas.

Desde el punto de vista político, las características fundamentales de la democracia, según García-Pelayo (2005) son:

- La voluntad y actividad del estado es formada y ejercida por los mismos que están sometidas a ellas.

- El pueblo; a quien se dirige el poder del estado, es al mismo tiempo sujeto de este poder, su voluntad se convierte en voluntad del estado sin apelación superior, el pueblo es, pues, soberano. 
CRISIS DE REPRESENTACIÓN COMO CONSECUENCIA DEL TRANSFUGUISMO POLÍTICO EN COLOMBIA

Por su parte Sartori (2002) también muestra tres aspectos: la democracia como principio de legitimidad, la democracia como sistema político y la democracia como ideal. "La democracia es un principio de legitimidad. En segundo lugar, la democracia es un sistema político llamado a resolver problemas de ejercicio (no únicamente de titularidad) del poder (...) la democracia es un ideal" (p. 29)

Aranzamendi (2006) argumenta que:

"la democracia se instituye en los Estados que cuenten con una Constitución, como norma fundamental que regula, entre otros aspectos, el sistema y régimen político. Igualmente indica que, para que la democracia y el estado funcionen, requieren de un orden jurídico de carácter sistémico, sustentado en una Constitución Política, que institucionalice determinados modelos o paradigmas de democracia, estructura del poder, formas de acceso al gobierno y el control o fiscalización del poder".(p. 67).

Así es que, para que la democracia cumpla con lo anteriormente expuesto, deben existir elecciones donde el ciudadano, mediante su voto, participe en elegir a sus representantes entre los candidatos propuestos por los partidos políticos, de acuerdo a esto, Dahl (1999), plantea que

"la representación resulta necesaria para la participación efectiva y control ciudadano del programa de acción, las elecciones libres, limpias y periódicas también son necesarias para la participación efectiva y la igualdad de votos; la libertad de expresión, las fuentes independientes de información y la libertad de 
CRISIS DE REPRESENTACIÓN COMO CONSECUENCIA DEL TRANSFUGUISMO POLÍTICO EN

asociación, son todas necesarias para una participación efectiva, un electorado informado y el control ciudadano del programa de acción" (p. 46).

Cuando se vincula la democracia, la representación, la participación y los partidos políticos; se consigue afirmar que no hay democracia sin partidos políticos. La democracia necesita de la representación y a su vez, no hay representación sin la existencia de partidos políticos. Las democracias representativas reconocen a los partidos políticos como las únicas esferas organizacionales válidas para influir la relación entre representante y representado, "Esta misma función se convierte en fuente de legitimidad para justificar el acceso a los roles de autoridad” (Kerz \& Pomposo, 2006).

Por otra parte, no se debe dejar de lado la definición del gobierno representativo que hace Stuart (2001), de la siguiente manera:

“[1]Que el único sistema de gobierno que puede satisfacer por completo todas las exigencias de la sociedad será un sistema en el que participe todo el pueblo; [2] que cualquiera participación, incluso en la más pequeña función pública, es útil; [3] que la participación deberá ser grande como el grado general de desarrollo que la comunidad lo permita; y [4] que, en el último término, nada puede ser más deseable que admitir a todos en la participación del poder soberano del Estado. Pero como cuando la comunidad excede las dimensiones de una ciudad pequeña no todos puede participar en los asuntos públicos, como no sea mínima proporción, de ello se sigue que el modelo ideal de gobierno perfecto ha de ser el gobierno representativo" (p. 94). 
CRISIS DE REPRESENTACIÓN COMO CONSECUENCIA DEL TRANSFUGUISMO POLÍTICO EN COLOMBIA

Por su lado, Dahl, (1999) indica que, el gobierno democrático, se caracteriza principalmente por su incesante capacidad para responder a las preferencias de los ciudadanos sin implantar diferencias políticas entre ellos y, para que esto se dé, los ciudadanos deben tener igual oportunidad para formular sus preferencias, manifestar públicamente dichas preferencias y recibir por parte del gobierno igualdad de trato.

Por lo mismo, en la democracia representativa, las disposiciones del colectivo son tomadas por personas electas, quienes reciben el nombre de representantes, los cuales ejecutan su labor en diversos estamentos del Estado.

Si se analiza la percepción de representación de Pitkin (1985) “el representado debe ser también capaz de acción y de juicio independiente, y no comportarse meramente como necesitado de cuidado" (p. 234), se infiere que el sujeto debe demandar, al gobierno al que pertenece, representación y que además se asuman las políticas que suplan las necesidades de los ciudadanos, haciendo que lo prometido en campañas se cumpla.

Manin (1998), encuentra el gobierno representativo como un instrumento efectivo para reconstruir la política y el papel activo del ciudadano en los sistemas representativos y afirma que "el gobierno representativo no es un sistema en el que todo se tenga que originar en el debate, sino aquél en el que todo ha de justificarse en el debate” (p. 233), tomando como base las diferencias que plantea sobre discusión, regateo, deliberación y debate.

Del mismo modo referencia que los gobiernos representativos fueron fundados como opuesto a la democracia y hoy se consideran una forma de la misma, señalando cómo el voto popular permite creer en la mentira de los gobiernos populares. Considera también que la representación es hoy más que nunca un gobierno aristocrático y de élites, realmente su concepto se centra en que es la forma más viable de democracia, siendo una especie de gobierno mixto, con elementos a la vez democráticos como aristocráticos. 
CRISIS DE REPRESENTACIÓN COMO CONSECUENCIA DEL TRANSFUGUISMO POLÍTICO EN COLOMBIA

Las características principales de los gobiernos representativos según Manin (1998),

Son:

- La elección periódica de los gobernantes

- La independencia relativa de los mismos para tomar decisiones

- La posibilidad de los gobernados de expresar sus deseos y opiniones políticas

- La existencia de un debate sobre las decisiones públicas.

La característica clave es que el consentimiento de los gobernados conlleva a que no haya límites para el poder de los gobernantes durante su mandato.

En síntesis, la representación política es mucho más que una simple relación entre sujetos: Implica también un vínculo entre el sujeto representado y el objeto de la representación; entre este sujeto y aquello que resulta de la representación. "En una democracia este es el vínculo entre el pueblo y la constitución, o entre el pueblo y la ley, o entre el pueblo y su gobierno" (Godoy, 2001), el mandato no implica una cercanía o una distancia entre quien hace la ley y quien lo elige, sino entre la ley misma y los ciudadanos. El que la ley, la constitución y el gobierno popular operen como si fueran la expresión de la voluntad general, depende de que la representación funcione como si fuera en verdad una representación del pueblo.

\subsubsection{Estudio de los Partidos Políticos.}

De acuerdo a la definición de partidos político dada por Sartori, (2002), es "cualquier grupo político identificado por una etiqueta oficial que presenta en elecciones (libres o no) 
CRISIS DE REPRESENTACIÓN COMO CONSECUENCIA DEL TRANSFUGUISMO POLÍTICO EN COLOMBIA

candidatos a cargos públicos” (p. 47). En esta definición se destaca que el objetivo del partido político es participar en elecciones logrando así promover el candidato que más convenga y sea afín a la elección popular. Es así que, los partidos políticos, son instituciones que desempeñan la situación política de representar e integrar varios intereses de la ciudadanía.

Por su parte Bartolini (1995), señala que el dinamismo de los partidos políticos está dado por la "participación en elecciones competitivas con el fin de que sus candidatos accedan a los cargos políticos representativos" (p. 81). De lo anterior se puede inferir que un partido político propende por encontrar el apoyo popular por intermedio de procesos electorales, lo que significa que un partido presenta un candidato a elecciones para que pueda acceder a algún cargo público.

Por otro lado, se encuentran definiciones que no están inmersas en procesos electorales, como lo ha establecido Artiga (2000), cuando afirma que un partido político es una “organización formal, de carácter estable y permanente y territorialmente extendida (...) un programa de gobierno con los objetivos a alcanzar por mínimo y abstracto que sea (...) objetivo de alcanzar y ejercer el poder político o de compartirlo, no conformándose con influir en el proceso de toma de decisiones" (p. 14).

Consideremos, ahora, un poco en los orígenes de las teorías que existen sobre partidos políticos, empezando por lo afirmado por Oñate (1997), “Los partidos surgen cuando la política deja de ser un asunto en el que sólo interviene una pequeña minoría, para constituirse en las organizaciones que mediarán entre el poder político (el Estado) y las masas de un "público ampliado"” (p. 254).

Por consiguiente, siguiendo un marco histórico, Zovatto ( 2011), indica que entre los años 70 y 80's, en la Tercera Ola dada en Latinoamérica, se dio paso del régimen autoritario al democrático por medio de elecciones libres y limpias, las cuales, aumentaron sustancialmente 
en éstos países constituyendo escenarios nuevos que establecieron una gradual reanimación de los partidos políticos que se encontraban a la sombra, hasta alcanzar a ocupar un lugar primordial en el establecimiento de los Estados.

Dentro de los antecedentes que precedieron a los partidos políticos, señala Sartori (2002) que en 1850, a excepción de Colombia y algunos pocos estados, no se conocían los partidos políticos como hoy en día y, solo en 1900, la creación de éstos fue unida a los comités y grupos parlamentarios originando una verdadera interacción entre ambos y, finalmente, se crearon colectividades externas diferentes, como, iglesia, periódicos, sindicatos, entre otros. (p. 55).

Así mismo, Zovatto (2011) manifiesta que "partido político” se inició a usar cuando se comenzó a reemplazar la palabra facción. El término facción, del latín facere (hacer, actuar), se refiere a un grupo político dedicado a un hacer (facere) perturbador y nocivo, a actos siniestros. A su vez, partido, del latín partire (dividir), que empezó a incursionar en el vocabulario político en el siglo XVII, expresaba, en sus inicios, la idea de parte evolucionando luego hacia la idea de participar. Su predecesor terminológico de larga data era el término "secta" (separar, cortar, dividir), pero éste terminó siendo utilizado en el ámbito religioso (Zovatto, 2011, p. 143).

Ya para 1770, Burke citado por Zovato (2011), fue el que diferenció sustancialmente ambos términos indicando que, los partidos, superan a las facciones porque no se basan sólo en intereses; sino también, en principios comunes. Así es que, Sartori (2002), dice que ya desde el siglo XIX los partidos se desarrollan y actúan más en cuestiones prácticas que en sus propias teorías. 


\subsubsection{Importancia y funciones de los partidos políticos.}

Hoy en día es avasalladora la existencia de los partidos políticos en los Estados ya que no podría existir la política sin ellos, Ware (2004), indica igualmente que los Estados que no tienen actualmente partidos políticos son los dirigidos por familias o sometidos a un régimen militar o a gobiernos autoritarios respaldados por ejércitos como es el caso de Cuba.

Las democracias son viables, en la medida que existan partidos políticos que las sustenten y por eso se observa que actualmente no hay a nivel mundial países democráticos sin la existencia de partidos políticos, como lo manifiestan Rosales y Rojas (2012): "las democracias son justamente una forma de gobernar caracterizada porque sus reglas y procedimientos se fundamentan en un mínimo indispensable de requisitos en su origen" (p. 27).

Los partidos políticos son vitales para la democracia ya que son "vehículos del pluralismo político" (Hernández Bravo (1997), los cuales se forman por personas con intereses comunes integrantes de un mismo grupo. En ellos están constituidas las diferencias políticas que a través de la historia muestra la sociedad, de modo que éstas pueden encauzarse inclusive por organismos cívicos e institucionalizados.

Los partidos se hacen indispensables para elegir e incorporar candidatos a diversos cargos políticos, son los entes avizores e institucionales dentro de un proceso electoral, organizan la cuestión pública con base en tesis de utilidad frecuente, establecen temas de intereses socioeconómicos, representan intereses y preferencias en la formulación de leyes y políticas; en síntesis, hacen parte esencial en las formas de gobierno.

Aunque los partidos tengan diversas facultades para el buen funcionamiento de la democracia, realmente la ciudadanía actual los percibe de forma negativa, por lo que hoy se 
CRISIS DE REPRESENTACIÓN COMO CONSECUENCIA DEL TRANSFUGUISMO POLÍTICO EN COLOMBIA

encuentran en incredibilidad, lo cual, se hace imperante resolver para beneficio de la estabilidad democrática.

De acuerdo al Latinobarómetro efectuado en el año 2011, en Latinoamérica se percibía una mejoría del $47 \%$ respecto a la democracia denotando, en los tres países comparados en el estudio, cifras como las observadas en la siguiente figura:

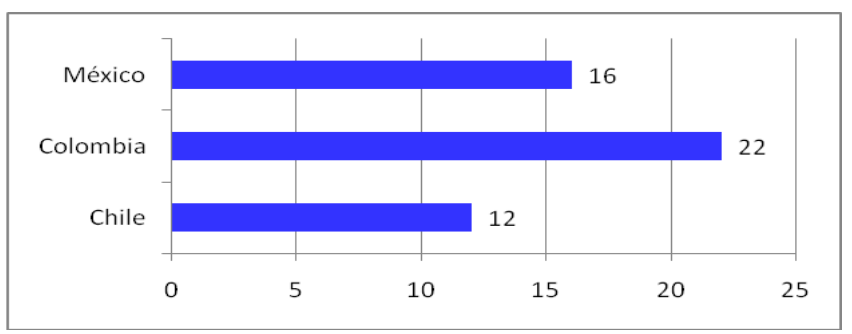

Figura 1. Mejoramiento de la Democracia

Fuente: Elaboración propia, con base en el Latinobarómetro (2011), p. 40

Del resultado efectuado por el Latinobarómetro, se evidencia que la mejoría en estos tres países ha sido significativa; sin embargo, existe en promedio en Latinoamérica un 6\% que arroja un resultado negativo con respecto al sistema democrático, por lo que la pregunta siguiente que debe hacerse es: ¿qué le falta a la democracia en cada país?, el mismo Latinobarómetro responde indicando es necesario reducir la tasa de corrupción constituida como consecuencia grave de la falta de gobernabilidad y de representación dando, como respuesta popular, una creciente abstención. 


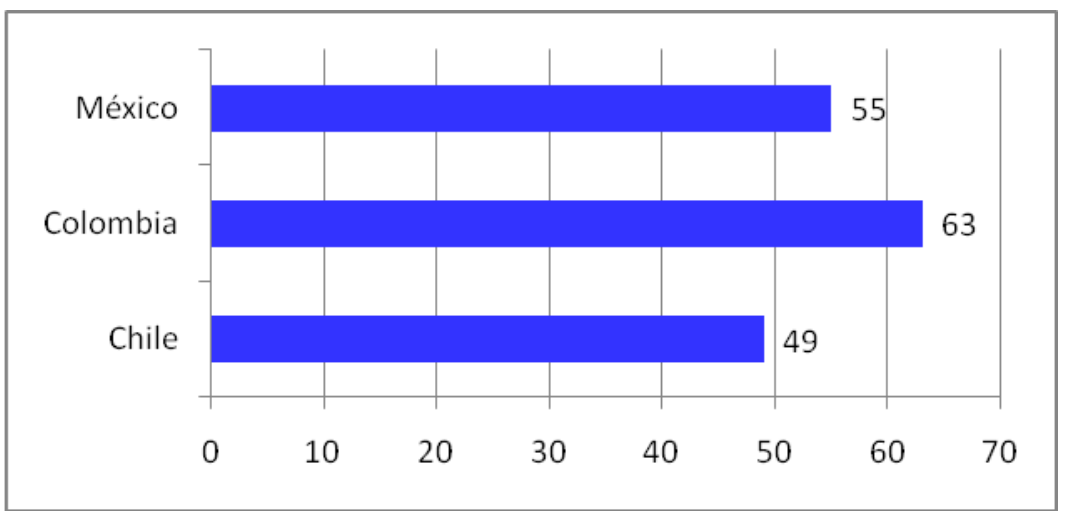

Figura 2. Falta reducir la corrupción - ¿Qué le falta a la democracia en su país?

Fuente: Elaboración propia, con base en el Latinobarómetro 2011, p. 41

Lo expresado en el Latinobarómetro del 2009, (citado por Zovatto, 2011), determina que, según datos de ese informe, el $76 \%$ de las personas entrevistadas declararon no tener confianza en los partidos políticos

[...] vemos que la confianza en ellos (los partidos) disminuye a medida que pasan los años, independientemente de que la gente los considere crecientemente válidos como instituciones de la democracia. Esto es particularmente interesante porque muestra una fuerte crítica a "los" partidos reales, mientras expresan al mismo tiempo un apoyo a la institución de los partidos como tal. [...](p. 145).

Contextualizando, los partidos políticos han evolucionado visiblemente ajustándose a los procesos políticos internos de cada país y, estos procesos, tienen que ver con la constitucionalización de los mismos. Chile y México ingresaron en los años 70 los partidos políticos a su constitución, aunque fue en 1978 cuando se dio inicio a la democracia. En la 
siguiente tabla se observa la entrada constitucional de los partidos políticos a cada país latinoamericano.

\begin{tabular}{|l|c|}
\hline \multicolumn{1}{|c|}{ País } & $\begin{array}{c}\text { Inclusión en la Constitución } \\
\text { Política }\end{array}$ \\
\hline Chile & 1970 \\
\hline México & 1977 \\
\hline Colombia & 1991 \\
\hline
\end{tabular}

Tabla 1. Año de ingreso constitucional de los partidos políticos.

Fuente: Elaboración propia, con base en (Zovatto D. , Regulación jurídica de los partidos políticos en América Latina, 2006)

De otro lado, los partidos políticos actualmente, como lo señala Alcántara (1997) median entre el sistema político y la sociedad, esto permite señalar que dentro de las democracias se evidencia la existencia de diferencias entre unos y otros, lo que ha generado la canalización de esos conflictos en procedimientos legales. De esto se desprende que las funciones de los partidos políticos se pueden clasificar en funciones sociales y funciones institucionales tal y como se muestra en la siguiente tabla. 


\begin{tabular}{|c|c|}
\hline Funciones Sociales & Funciones institucionales \\
\hline Formar, articular y canalizar la opinión pública & $\begin{array}{l}\text { Reclutar a las élites dirigentes, seleccionar a los } \\
\text { candidatos que se presentarán a elecciones y } \\
\text { ocuparán cargos públicos y designar los cargos } \\
\text { políticos en la administración }\end{array}$ \\
\hline $\begin{array}{l}\text { Transmitir determinados valores y pautas de } \\
\text { conducta que es tructuran identidades políticas }\end{array}$ & $\begin{array}{l}\text { Canalizar las opciones de la ciudadanía en el } \\
\text { procedimiento electoral }\end{array}$ \\
\hline $\begin{array}{l}\text { Canalizar parte de la pluralidad de intereses de la } \\
\text { sociedad }\end{array}$ & $\begin{array}{l}\text { Realizar actividades como las campañas electorales, } \\
\text { la elaboración y difusión de programas, la } \\
\text { participación en el escrutinio y el control de las } \\
\text { votaciones }\end{array}$ \\
\hline $\begin{array}{l}\text { Transformar y concretar las demandas e intereses de } \\
\text { la sociedad en medidas y decisiones políticas por } \\
\text { parte de las instituciones }\end{array}$ & Participación formal en la contienda electoral \\
\hline $\begin{array}{l}\text { Movilizar a la opinión pública, haciendo posible la } \\
\text { participación política, fuera y dentro de las } \\
\text { instituciones }\end{array}$ & Formar, dirigir y controlar la acción de Gobierno \\
\hline $\begin{array}{l}\text { Restringir la participación a los límites jurídicos del } \\
\text { sis tema, limitando el conflicto }\end{array}$ & $\begin{array}{l}\text { Organizar y componer el parlamento, con todas las } \\
\text { funciones que es to implica }\end{array}$ \\
\hline $\begin{array}{l}\text { Integrar y legitimar el sistema político, ya que } \\
\text { mediante los partidos se discuten y controlan las } \\
\text { decisiones políticas }\end{array}$ & 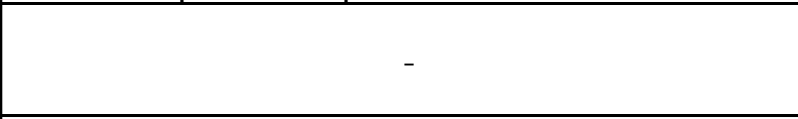 \\
\hline $\begin{array}{l}\text { Moderar las posiciones de la sociedad civil al } \\
\text { canalizar el conflicto y la protesta hacia las } \\
\text { instituciones }\end{array}$ & - \\
\hline
\end{tabular}

\section{Tabla 2. Funciones Partidos Políticos}

Fuente: (Oñate, P. 1997, p. 262-264).

Esta temporalidad histórica fija la forma en que fue entendida y practicada la democracia como principio y modo de organización de la convivencia social desde los tiempos que antecedieron a la revolución francesa de 1789.

Por último, viendo la representación política como la herramienta necesaria para la práctica de la democracia y, si bien su significación y aplicabilidad depende de los momentos históricos y los establecimientos espaciales en que se pone en práctica, es necesario enfatizar que ésta es productora de identidad y de pertenencia dentro del poder constituido.

\subsection{Nociones sobre Sistemas de Partidos y sus tipologías.}


CRISIS DE REPRESENTACIÓN COMO CONSECUENCIA DEL TRANSFUGUISMO POLÍTICO EN COLOMBIA

Generalmente se llama Sistema de Partidos a los grupos que se encuentran conformados por un modelo de estructuras e interacciones que son más o menos estables entre las distintas unidades de partidos pertenecientes a sistemas democráticos consolidados, con organización interna, con alianzas y estrategias y con vínculos con la sociedad y las instituciones políticas.

Los sistemas de partidos desde, este punto de vista, cuentan con propiedades específicas que son distintas de las de los partidos considerados individuales, que constituyen estructuras diferenciadas que no pueden ser entendidas como la suma de estos. En los sistemas democráticos no se puede pensar en partidos aislados.

Así como lo arguye Vega (1996) "los sistemas de partidos son considerados como un subsistema del sistema político, con el que están en permanente interdependencia” (p. 81), constituyéndose uno de sus elementos fundamentales el reflejar su grado de diversidad y pluralismo, ordenar los temas de debate político y proponer las soluciones a los conflictos, así como articular las demandas políticas y las respuestas a algunas de éstas para contribuir de forma decisiva a la labor de gobierno.

La interrelación entre un sistema político y un sistema de partidos es tan estrecha que no es difícil caracterizar básicamente al primero con el segundo, pero de acuerdo a lo referenciado por Ware (2004), las características de los sistemas de partidos hacen referencia a los diferentes modelos de interacciones competitivas entre sus unidades, poniendo de manifiesto la concentración - dispersión del poder y cuestiones como su mayor o menor complejidad, hasta determinar que existen cuatro rasgos básicos que permiten diferenciar y clasificar los distintos sistemas de partidos: 1.- la capacidad de penetración de los partidos en la sociedad; 2.- su ideología; 3.- su posición respecto a la legitimidad del sistema político y 4.su número. (p. 149) 
CRISIS DE REPRESENTACIÓN COMO CONSECUENCIA DEL TRANSFUGUISMO POLÍTICO EN

En cuanto a la capacidad desigual de penetración ante la sociedad, se puede establecer que existen grandes diferencias en los partidos: pueden situarse entre los extremos de caracterización por vínculos muy débiles entre éstos y sus electores, con una incidencia escasa para la vida de la gente; o por los vínculos profundos entre los electores y los partidos, representando una gran parte en la sociedad al prevalecer una fuerte identificación entre ciudadanos a los movimientos políticos. Cuando el discernimiento social de los movimientos políticos es bajo, es más factible la instauración de nuevos partidos políticos que compitan con éxito con los ya existentes.

De otro lado, la doctrina contribuye de manera reiterativa la caracterización de los sistemas de partidos explicando su funcionamiento. Así mismo es importante para la configuración de un sistema de partidos la postura de éstos teniendo en cuenta los criterios de legitimidad del sistema político y su representación en sólidos partidos anti-sistema que pueden plantear graves problemas de gobernabilidad reduciendo las alternativas del propio gobierno.

Al mismo tiempo, Duverger citado por (Ware 2004), referencia que los sistemas de partidos son el producto de múltiples y complejos factores que pueden ser específicos de cada país tales como la tradición y la historia, la estructura socioeconómica, las creencias religiosas o los conflictos étnicos; así como de factores generales que es el caso el régimen electoral, factor muy importante para Duverger porque condiciona, de forma decisiva, cuatro aspectos básicos de los sistemas de partidos a saber: el número de partidos; la dimensión de estos; las alianzas y la representación. (p. 184)

Por otro lado el autor Sartori (2002), realiza una clasificación de los sistemas de partidos tomando en consideración el criterio numérico, pero añadiéndole un factor dinámico, que él considera como una variable crítica consistente en la polarización o distancia entre los 
partidos que compiten entre sí. Sartori, toma como referencia principalmente la dimensión izquierda- derecha; distingue entre espacios políticos competitivos estrechos, en los que se produce una polarización baja y una política agregativa, y espacios políticos competitivos amplios, en los que hay una polarización elevada y una política conflictiva. Para éste autor, es importante resaltar que, para caracterizar un sistema de partidos, debe tenerse en cuenta el sentido o dirección de la competencia partidista, por un lado centrípeta; es decir, cuando los partidos tienden a la moderación y la competencia se dirige hacia el centro tratando de ganar el electorado moderado, y por otro lado, centrífuga, es decir, cuando hay una tendencia de los partidos, o de algunos de ellos, a defender políticas radicales y el desarrollo e implementación de esa competencia.

Por su lado Bartolini (1995), indica que el sistema de partidos es "el resultado de las interacciones entre las unidades partidistas que lo componen; más concretamente es el resultado de las interacciones que resultan de la competición electoral” (p. 219), así es que, el sistema de partidos, va más allá de la suma de los partidos que están inmersos porque involucra, además de lo anterior, la interacción de todas sus partes.

Los sistemas de partidos tienen varios componentes específicos y características, que suelen salir de acuerdo a sus interacciones entre los partidos políticos, a manera de ejemplo como lo indica Artiga (2000) se tiene en cuenta el número de partidos que tienen un sistema, una fuerza electoral, una distancia ideológica entre partidos que diferencian el cómo desempeñan su competencia electoral, además de su condición frente al sistema político. ( p. 89)

\subsubsection{Cambios en los Sistemas de partidos}


Analizando diversas variables que suelen afectar los partidos y sus sistemas, entre otras están, el número de partidos significativos, su analogía con las segmentaciones sociales, su mayor o menor institucionalización, la vigilancia democrática sobre ellos, la formación de alianzas y la estabilidad gubernamental en los sistemas legislativos, las alineaciones electorales, la ideología, la organización y eficiencia internas, las formas de acción o sus pautas de competencia, los porcentajes de votos...; variables que hacen que los sistemas de partidos estén en constante cambio, porque los partidos deben adaptarse a las situaciones cotidianas que van surgiendo, pues si no lo hacen, es inevitable su debilitamiento y su posterior extinción.

Asimismo, hay que tener en cuenta que, junto a una compatibilidad interna en la que sus miembros se identifican y reconocen la misión y visión en los ideales propuestos, igualmente llevan a cabo objetivos comunes a su colectivo mediante la existencia de una identidad externa que contrasta las diferencias respecto a los otros partidos; como la relación entre el hecho del militante y el del votante.

Para el militante la identidad interna es de mayor jerarquía, en razón a que un partido puede mantenerse luego de una derrota electoral una vez que sus militantes cierren filas. Para el votante, la identificación con un partido se origina en una situación dispuesta de contraste con otros partidos del sistema, tomando como referencia cuestiones como las de sus reclamos o la imagen, con independencia de su historia y de vínculos de solidaridad internos, etc. (Montero \& Gunther, 2004).

Uno de los cambios más significativos que pueden sucederse en los sistemas de partidos es el de realizar una modificación en el orden organizativo que transforma la estructura de su propia autoridad y que cambia la configuración de la coalición partidista dominante trayendo, como consecuencia, un control distinto de los incentivos y una 
reestructuración de los juegos de poder de las élites tanto verticales como horizontales (Panebianco, 1990, p. 455).

Cuando el funcionamiento de los partidos políticos y sus sistemas decaen, producen una crisis de representación provocada por la falta de institucionalización de los mismos, aunado a las diversas causas sociales que viven los países en su momento, decaimiento que hace necesario revisar si la democracia establecida cumple con los poderes otorgados por el electorado y, así mismo, observar si la ciudadanía toma como opción inicial los partidos y sus sistemas para el buen ejercicio de la democracia, cuyo resultado es importante contextualizar, para analizar el porqué de la crisis de la representación.

\subsection{Crisis de Representación Política}

Las teorías expuestas anteriormente, permiten deducir que la representación debe partir de una estabilidad política ${ }^{11}$ debido a que los sistemas de partidos políticos se orientan en procesos de consolidación democrática con garantías sociales amplias, tomando como primera medida la ampliación de las elecciones que aseguran la permanencia de los partidos dentro del sistema. Este es uno de los paradigmas que de descuidarse avizora la presencia de la crisis de la representación.

Al respecto, se puede inferir que, como lo manifestaba Alcántara (1997):

\footnotetext{
${ }^{11}$ Referente a la estabilidad política, se puede consultar a Buquet (2012), el cual dice explícitamente: "si un sistema de partidos institucionalizado es un sistema en equilibrio las elecciones deberían ofrecer relativamente baja volatilidad y, al mismo tiempo, estabilidad en el número de partidos". Esto sugiere que la estabilidad política aumenta la credibilidad y minimiza el riesgo de crisis de representación política.
} 
“[...]la creencia de que la institucionalización de la política es cosa de un día y los partidos la institución adecuada para esto, conlleva a una crisis de representación de los partidos como instituciones esenciales de la vida electoral, que se fundamenta en el rechazo de los electores. Ésta crisis referida, no es estricta a la relación institucional sociedad - partidos, sino a situaciones que presenta el Estado en su proceso de transformación [...]"(p. 37-57).

La crisis en la representación, generalmente se ha demostrado dentro del proceso de toma de decisiones por parte de los ciudadanos en el ejercicio electoral, oportunidad que les permite mostrar su participación política. Es donde el voto se convierte en la forma más masiva de participación en las democracias modernas. Una baja participación electoral induce directamente un problema de representatividad, la baja participación es un problema para el buen funcionamiento del sistema democrático, ya que amenaza su legitimidad como tal.

Otro problema de representación está dado por la relación entre el representado y el representante, relación que tiende a disponerse más lejana y, en algunos casos, a disociarse, distancias propiciadas, entre otras, por el cambio de las estructuras políticas y de las formas de gobierno que a su vez se relacionan con el incremento en los votos y la expansión en las elecciones, como ya se mencionó.

El problema central radica, entonces, en la disociación entre el representante y el representado: en que el derecho al voto, (tema fundamental como se ha evidenciado), no determina la responsabilidad, del mismo modo que la elección por sí misma tampoco la garantiza correspondiéndole al gobierno, en consecuencia, generar campos sistemáticos de representación política. 
“(...)La noción de crisis de la representatividad se vincula por una parte con la percepción de una distancia entre la sociedad y el gobierno. El análisis de diferentes formas de gobierno representativo muestra que la representación no siempre ha constituido un reflejo de las relaciones sociales. La representación sólo se convierte en reflejo de una situación social particular, cuando una división social supera a las demás y se impone con evidencia como la escisión primordial” (...). (Manin, 1992, p. 40)

El problema de representación implica, no solo el sistema de partidos, el sistema electoral y la configuración en general del representante, sino que también implica la estructura del representado.

Autores como (Gargarella 2002) ${ }^{12}$ y Paramio (2002), atribuyen la crisis a las limitaciones de la oferta partidaria y a los resultados insuficientes de los gobiernos en las nuevas circunstancias creadas por la globalización; factores que generan descontento en la mayoría de la ciudadanía.

Se empieza a denotar una separación contundente que se evidencia en las elecciones, con índices de abstención cada vez mayores y, cuyo resultado, se ve en que los procesos de representación y los sistemas de partidos que tienen una gran deserción, causando la deslegitimación de los partidos habituales y ocasionando la creación de nuevas instituciones que planteen diversas formas de reconstruir la democracia como imprescindible necesidad de identificación y de representación manifestada, definitivamente, en la relación que debe existir entre la ciudadanía y las instituciones.

\footnotetext{
${ }^{12}$ Gargarella, R. (2002). Crisis de la representatividad política. México: Fontamara. señala que más allá de coyunturales problemas que giran en torno a la representación política y su consecuente crisis, las instituciones propias del sistema representativo tienen mucho que ver con la forma en que tales instituciones fueron diseñadas; por lo cual la crisis de la representación está más vinculada con las instituciones que con los propios representantes
} 
Ésta reconstrucción le abre paso a nuevos actores comúnmente llamados “outsiders”, como lo señaló Henriquez, (2010, p. 634), cuya aparición hace comenzar una nueva etapa que surgió como una personalización política como respuesta a la crisis de representación suscitada; aunque, realmente, estos nuevos esquemas no evidencian contextos democráticos, sino que reúne grandes sectores sociales haciéndolos partícipes de discusiones sobre reformas del Estado. Así lo manifiestan Zovato y Orozco (2008) "se concentró en la implementación de paliativos a través de políticas asistencialistas, que no serían otra cosa más que el resultado de la pragmatización de la política proyectándose como la democracia en funcionamiento" ( $p$. 107).

De acuerdo con Gargarella (2002), la crisis de representatividad se inició con la formación de élites, las cuales, sobresalían por su modo de vida y posición social, indicando que las corporaciones que toman al sistema representativo "fueron diseñadas conforme a presupuestos elitistas, que hoy nos resultarían claramente contra intuitivos" ( p. 9-10)

Por otro lado y como se indicó anteriormente, al ir creciendo la población votante, las perspectivas puestas en las elecciones se expandieron volviéndose un punto central para la democracia tal y como lo manifiesta Annio (1995): "El voto se transformó así en un acto cargado de un fuerte valor simbólico y artificial a la vez, porque el nuevo ciudadano votando no escogía sólo a una persona para gobernar las leyes, sino que le encargaba ejercer la soberanía de la cual el votante era el dueño" ( p. 183).

De esta forma, la crisis comienza a ser más directa, puesto que, las elecciones, se convierten en herramientas que no denotan la representación; sino que resulta cediéndole a los gobernantes todo el poder de decisión que hace exclamar al autor Manin (1992): 
“(...) la representación experimenta actualmente una crisis en los países occidentales. A lo largo de décadas parecía fundarse en una relación de confianza, fuerte y estable, entre los electores y los partidos políticos; la mayoría de los electores se identificaba con algún partido político y le era fiel por largo tiempo. Hoy, un número creciente de electores vota de manera diferente en cada elección y las encuestas de opinión revelan que aquellos que se niegan a identificarse con un partido político también aumenta. (...) En el presente, la estrategia electoral de los candidatos y de los partidos políticos se basa en la construcción de imágenes bastante vagas en las cuales la personalidad de los líderes ocupa un lugar predominante (....) La elección de los representantes no parece ya ser el medio por el cual los representados escogen la política que desearían se aplique(...)”(p. 11)

Lo anterior, involucra la crisis de la representación democrática que se da entre gobernantes y gobernados, donde se establece que el representado no tiene control sobre el representante lo que permite que se abra una brecha entre ambos, producto de la falta de diseños y exposiciones de propuestas asociadas a demandas de la ciudadanía que sean concretas y reales. En ese mismo sentido, la crisis de representatividad tiene que ver con la individualización de la representación y el trayecto entre el partido que es elegido para el gobierno y el individuo que aspira a la representación.

Es más, la afinidad de los representantes no es en conexión a los mismos electores; sino respecto a grupos más pequeños de ciudadanos, los cuales, pretenden como fin principal la conservación del poder degenerando el sistema de partidos en detrimento de la democracia y permitiendo el nacimiento de la plutocracia, (método interno de los partidos políticos que 
CRISIS DE REPRESENTACIÓN COMO CONSECUENCIA DEL TRANSFUGUISMO POLÍTICO EN COLOMBIA

establece un nuevo vínculo), una concepción nueva de mandato dominante y autoritario en favor de los representantes que así buscan afianzarse en el partido transformando la democracia de partidos en una democracia secundaria, o del parlamento, donde la voluntad colectiva que predomina es la establecida por los que han salido elegidos gracias a los votos mayoritarios de los ciudadanos.

"Seguir hablando, por ejemplo, de mandato representativo, cuando todos sabemos que los diputados obedecen las órdenes de los partidos, o continuar sosteniendo que los representantes representan a toda la Nación y no intereses particulares y concretos, equivaldría a seguir manteniendo un concepto de representación y de democracia representativa que, en frase de Morstein-Marx, hace ya tiempo que forma parte de la arqueología constitucional” (Vega, 1996, p. 23)

Igualmente como lo planteado por Kelsen (1977), los derechos políticos se reducen en síntesis a un mero derecho de sufragio.

“(...) ante la presencia de unos partidos rígidamente organizados, el representante se convierte más en el portavoz del partido que de cualquier otra instancia, incluyendo a sus propios electores; y sus vinculaciones partidistas tienden a ser más fuertes que cualesquiera otras (...)" (Torres del Moral, 1982, p. 15)

Por lo mismo, los partidos se rigen bajo unos intereses específicos de la cúpula política que los gobierna, y en ciertas oportunidades lo que los mueve son intereses de índole 
económico que no son conocidos por la ciudadanía, acciones constituidas por instituciones blindadas frente a las peticiones, necesidades y demandas de la comunidad.

Así como se presentaron diversos cambios en la representación política o de partidos cuyas transformaciones condujeron a la crisis actual de representación, igualmente, demostraron que esos cambios no pueden revocar los partidos políticos y, por tanto, sí se pueden generar elementos que conllevan a una mayor participación ciudadana y que, por esa misma vía, la población puede llegar a tener deliberación en los escenarios políticos, creando mayor fiscalización y control a los sistemas representativos del momento.

La crisis concibe fuertes sentimientos de insatisfacción de la población respecto del funcionamiento de las instituciones; esa asonada de desconfianza y descrédito se reproduce cuando se describe la pasividad de los partidos políticos ante el alto índice de corrupción que corresponde claramente a una distribución de cargos y posiciones donde priman, en todo tipo, de organizaciones gubernamentales, influencias de políticos profesionalizados en buscar sus propios intereses abusando del sagrado manto de la representación.

La incapacidad para vigilar e intervenir en ese tipo de situaciones evidenciada por gobiernos de diferentes partidos, hace que se disminuya, ostensiblemente, la popularidad con la que contaban en el momento de la elección, aspecto que se articula con la propagación de casos de corrupción dando, como resultado, un gran descontento que se traduce en una crisis sistémica, con manifestaciones abiertas realizadas en la calle y con informes y comentarios ante los medios de comunicación sobre la pérdida de legitimidad democrática, la crisis de la representación política, las deficiencias de las instituciones en general..., tanto así que cuando se difunden las pugnas entre los representantes de los partidos políticos se convierten en agravios personales. 
Una de las modificaciones propuestas se refiere a algunos aspectos del sistema electoral que pueda generar efectos positivos para el funcionamiento de la representación, como lo señala Dahl (1999), “una razón por la que difieren tanto es que ningún sistema electoral puede satisfacer los criterios de enjuiciamiento a los que razonablemente podríamos someterle. Hay como siempre una transacción de alternativas” (p. 152)

En síntesis, la crisis de los partidos políticos y de los poderes legislativos se ha dado porque poco a poco pierden funciones trascendentes ante la sociedad, lo que sin duda exige a la democracia actual replantearse y presentar formas y modelos de representación y participación políticas que restablezcan el equilibrio en la actividad sociopolítica.

Una vez estudiadas las teorías y el alcance histórico de los conceptos requeridos para el análisis de esta investigación, se realizará a continuación una descripción de los sistemas de partidos actuales dentro de las democracias en Colombia y su comparación con Chile y México y, cómo la desconfianza que los sistemas han generado en cada uno de estos países, ha dado paso a movimientos sociales que hoy son grandes protagonistas aprovechando la salida de personas de los partidos políticos tradicionales y dando surgimiento al "trasfuguismo", tema que se aborda en este tratado de manera especial. 
CRISIS DE REPRESENTACIÓN COMO CONSECUENCIA DEL TRANSFUGUISMO POLÍTICO EN COLOMBIA

\section{Capítulo II. El trasfuguismo político y sus consecuencias en la representación de}

\section{los partidos políticos}

Este segundo capítulo comprende el estudio de la figura denominada Trasfuguismo, como una consecuencia de las investigaciones que sobre partidos políticos y sistemas de partidos se analizó en el capitulo anterior, y que han tomado un gran interés en América Latina demostrando una renovada preocupación por este tema que se había relegado en presencia de otros asuntos de mayor comprensión y análisis, como los problemas de desarrollo económico, social y político; aunque a nivel mundial el interés sobre Latinoamérica se relegó, hubo investigaciones serias ${ }^{13}$ en torno a la materia que ocupa esta tesis, y que se aborda de la siguiente forma:

\subsection{Transfuguismo Político}

\subsubsection{Introducción y antecedentes al fenómeno del transfuguismo político.}

El transfuguismo político tiene unas dimensiones y una relevancia en la representación política dentro de un Estado de derecho y de una democracia representativa de partidos porque, como lo manifiesta Perícola y Linares, s.f (2014):

"los representantes llevan una representatividad configurada en las urnas sobre la base de la adscripción política a un partido político, de modo que cuando el

\footnotetext{
${ }^{13}$ Los trabajos de investigación más relevantes en América Latina están los aportados por Daniel Zovato (1995, 2006, 2008), Alcántara (1997), entre otros.
} 
CRISIS DE REPRESENTACIÓN COMO CONSECUENCIA DEL TRANSFUGUISMO POLÍTICO EN COLOMBIA

Diputado o Senador nacional decide unilateralmente no incorporarse al bloque parlamentario que corresponde con el partido político bajo cuyos pronósticos asistió a la contienda electoral o, más frecuentemente, abandonar dicho bloque parlamentario e incorporarse a otro, se produce entonces una distorsión de aquella representatividad" (p. 250).

El paso de un representante de un grupo político a otro diferente al que formaron parte en el momento de ser elegidos, se ha convertido en un fenómeno preocupante de la vida democrática porque, no solo ha ido en aumento; sino que, como resultado de los cambios que se operan en la relación de fuerzas iniciales, se quebranta el resultado auténtico de la voluntad de las libertades democráticas.

De acuerdo con Cuéllar (2012), el comportamiento tránsfuga podía considerarse como una aberración fruto de un sistema corrupto, ficticio y oligárquico, actualmente se debe reorientar el análisis puesto que la traición de la que se sirve, supone el agravamiento de la crisis de representación política, y con ello, socava los cimientos de los sistemas democráticos actuales (p. 63).

Ese comportamiento se ha venido repitiendo a través de la historia colombiana por diferentes líderes que, en su momento histórico acaecieron, conforme a la versión expuesta por Zwerg-Villegas, (2012) que sintetiza de forma clara y concisa los acontecimientos de épocas pasadas con relación al transfuguismo.

A continuación se toma de forma literal el recuento del transfuguismo en la historia elaborado por Bushnell (1993), citado por Zwerg \&Villegas (2012):

"La Revolución de los Comuneros que se originó con una revuelta de las clases pobres criollas y mestizas para protestar por los nuevos impuestos sobre tabaco 
y alcohol revuelta que, rápidamente, recibió el apoyo y liderazgo por parte de las clases afluentes que sin duda simpatizaron con el movimiento; pero que no estaban lo suficientemente comprometidos para arriesgarse tanto que, muchos de los líderes voluntariamente elegidos, prepararon comunicados a las autoridades coloniales expresando sus reservas y atestiguando que fueron elegidos bajo presión.

Sin embargo, a pesar de los vaivenes de los líderes, la revolución consiguió una tercera parte de la población de la Nueva Granada y juntos forzaron a que las autoridades del momento ofrecieran las concesiones que buscaban y, cuando se creía el total éxito, los oligarcas locales traicionaron al movimiento atemorizados por el auge en radicalización, situación que fue aprovechada por el Virrey quien, inmediatamente denunció toda concesión, ante la perplejidad del pueblo de ver que sus líderes no hicieron nada para renovar la protesta

Antonio Nariño jugó un papel importante en el inicio del proceso de Independencia, cuando en 1739, imprimió y distribuyó varias copias de la Declaración de los Derechos del Hombre y del Ciudadano que tradujo del idioma Francés, a pesar de que una vez publicadas, se repentizó e intentó tomar de vuelta las copias distribuidas y, en el caso penal que se adelantó en su contra, fabricó tres distintas mentiras y excusas por sus actos y más adelante, Nariño se volvió tránsfuga al asumir poderes dictatoriales durante su reino en la Patria Boba (1810-1816).” (Bushnell, 1993, citado por Zwerg\&Villegas, 2012).

Simón Bolívar también actuó de forma tránsfuga cuando asumió poderes dictatoriales en la Asamblea de Notables en 1828; aunque ese no fue el primer vaivén en su ideología. Un declarado anti-federalista colaboró con la causa federalista en la Nueva Granada en 1814. En otra ocasión, con sus diferencias en aumento, Bolívar no 
tomó ninguna acción en contra de la rebelión de General José Antonio Páez y la deslealtad que éste mostró hacia el Vice-Presidente Francisco de Paula Santander. Un último ejemplo de Bolívar es probablemente el más impresionante: su gabinete, sin seguridad de haber actuado con o sin el conocimiento de Bolívar, se acercó a las monarquías de Inglaterra y de Francia para ofrecerles la nación en el momento de jubilación política o muerte de Bolívar (Bushnell, (1993), citado por (Zwerg-Villegas (2012)

Santander consideró el modelo constitucional bolivariano como una monarquía disfrazada y una traición contra los principios republicanos por los cuales se había luchado contra España. Igual a Bolívar, tuvo sus vaivenes entre federalismo y centralísimo, porque vociferó en contra del sistema federalista y luego, como vicepresidente, cuando se encontró en una relación política difícil con Bolívar, vio en el federalismo una medida estratégica para debilitar el control bolivariano sobre la nación, recibiendo; entre otros, apoyo del Coronel José María Obando, quién en la Guerra de Independencia primero estuvo al servicio real y luego pasó a las filas patriotas. En el Congreso de Cúcuta en 1821, muchos de los federalistas decidieron no apoyar a Santander, porque estaban en minoría, que los llevó a satisfacer a Bolívar y ganarse posiciones más importantes en su administración (Bushnell, 1993) citado por (Zwerg-Villegas, 2012)

En el año de 1849, los dos partidos políticos tradicionales nacieron de la lucha entre Bolívar y Santander. En la mayoría, los seguidores de Bolívar y del centralismo formaron el partido Conservador. Los seguidores de Santander no se ubicaron tan claramente en uno de los partidos. Como Santander, muchos de ellos mostraron agilidad en cambiar sus ideologías y de partido. El sistema bipartidario 
recibió su primer desafió con la segunda candidatura del ex-presidente conservador Tomás Cipriano de Mosquera, quien como no ganó las elecciones para un tercer periodo en 1857, "se volvió liberal” y llevó la nación a la victoria en la guerra civil contra Mariano Ospina Rodríguez, quien igualmente fue ejemplo de trásfuga al pedir a su embajador en Washington de que explorara la posibilidad de que los Estados Unidos anexara a la Nueva Granada.

Uno que "se volvió conservador" fué Rafael Núñez, quien lideró la Regeneración (Bushnell, 1993). Como parte de su táctica, integró la participación activa de la Iglesia en su administración a pesar de no ser hombre religioso; entendió que la Iglesia serviría en la cooptación del pueblo. (citado por Zwerg-Villegas, 2012).

El héroe folclórico, Marco Fidel Suarez, también merece atención como tránsfuga. A pesar de provenir de la clase humilde, durante su presidencia (1918-1921) hizo poco para el pueblo común y corriente, y permitió la desmembración del territorio de Panamá.

Con brinco a las décadas más recientes, se evidencian los continuos vaivenes de ideologías y de lealtades y el transfuguismo motivados por el oportunismo. Las FARC, el ELN y el M-19 se formaron bajo supuestos ideológicos, llegando a la lucha armada, la que les sirvió de excusa para entrar en acuerdos con grupos de ideologías contradictorias que los llevaron a cometer actos no representativos de sus causas en contra del pueblo que decían defender. (pp. 11-13)

\subsubsection{Conceptos del Transfuguismo político}


CRISIS DE REPRESENTACIÓN COMO CONSECUENCIA DEL TRANSFUGUISMO POLÍTICO EN COLOMBIA

El diccionario de la Real Academia Española de la Lengua define como tránsfuga, aquella "persona que pasa de un partido a otro". Jurídicamente se puede definir el transfuguismo como el fenómeno consistente en el paso de un representante elegido en las listas de determinado partido político a otro partido diferente a lo largo de la misma legislatura o mandato conservando, en este cambio, la propiedad de su escaño. (Vera, 1997).

Dentro del aspecto de la línea política (Mallén, 2002), la definición del transfuguismo:

"consiste en ubicarse voluntariamente en una posición representativa distinta a la pretendida por el partido o formación en cuyas listas se presentó ante los electores, bien desde el inicio del desempeño del cargo público representativo, bien posteriormente a causa de un cambio de grupo.” (p.32)

De igual forma este autor, argumenta que la condición personal sine qua non para devenir tránsfuga consiste en desempeñar un cargo público representativo, entendiendo por tal el ejercicio en organizaciones públicas con base territorial en virtud de una relación democrática de representación política originada por una elección de ciudadanos (Mallén 2002) ${ }^{63}$ (p. 34). Por ello, puede hablarse de transfuguismo en los ámbitos nacional, provincial y local o municipal, dependiendo de la ubicación del cargo que se ejerza o represente.

Por su lado, Perícola y Linares (2004), indican que:

“(...) el transfuguismo consiste en ubicarse voluntariamente en una posición representativa distinta a la pretendida por la agrupación política en cuya lista se 
CRISIS DE REPRESENTACIÓN COMO CONSECUENCIA DEL TRANSFUGUISMO POLÍTICO EN

presentó ante los electores, bien desde el inicio del desempeño del cargo público representativo, bien posteriormente a causa de un cambio de bloque parlamentario". Así las cosas, se puede hablar de un transfuguismo inicial o abinitio y de un transfuguismo sobreviniente o por cambio de bloque político (...) (p. 251)

Así mismo y de acuerdo con Passarelli (2011), tránsfugas se les dice a las personas quienes obtienen un puesto de elección popular con el apoyo a sus candidaturas por un determinado partido político y, una vez ganada la elección, durante el desempeño de sus funciones, renuncian a la filiación del partido político que los respaldó e incluso se afilian a otro. La literatura política argumenta que este tipo de conductas obedece, en muchos casos, a estrategias partidarias, a fin de obtener triunfos electorales.

Por otro lado Fortin (2010), argumenta que la decisión de migrar de un partido a otro obedece a un cálculo racional (costo/beneficio) que realiza el político para maximizar su probabilidad de reelección.

El transfuguismo se produce especialmente en los sistemas de partidos multipartidistas debido a que, el paso del representante, se produce no hacia el otro extremo ideológico sino hacia posturas más cercanas al centro político o hacia partidos de similar ideología.

El problema real es cuando un candidato elegido en la misma legislatura abandona la disciplina del partido político que lo ayudó en elecciones y al cambiar, con su voto desequilibra el juego mayoría de gobierno - minorías de oposición. Así pues, como lo manifiesta Vera (1997), con estos avatares se da paso a la corrupción y al intento de alcanzar; mediante pactos poco creíbles, beneficios para la sociedad civil, que se convierten en 
CRISIS DE REPRESENTACIÓN COMO CONSECUENCIA DEL TRANSFUGUISMO POLÍTICO EN COLOMBIA

propósitos de apoyo el gobierno de turno, que satisfacen propósitos personalistas, aún traspasando los dinteles de la licitud, fenómeno reprobable jurídicamente en cuanto a la función del partido político $^{14}$, porque se convierte en instrumento fundamental para la desarticulación de la participación política.

Igualmente, transfuguismo puede significar migración, cuando un integrante de un partido se separa de la agrupación política que lo llevó al seno legislativo para unirse a un partido político diferente. Ésta es una actividad que no ocurría con bastante frecuencia, porque era considerada una práctica inmoral, pero hoy, el hábito de fugarse para otro partido se ha vuelto más que frecuente, perdiendo su carácter ético, en la medida en que se justifica al evidenciarse un resquebrajamiento institucional del partido sometido a presiones públicas, como consecuencia de temas relevantes que conllevan a contradicciones políticas en su organización.

A manera de síntesis, podemos decir que el transfuguismo es aquel fenómeno de movilidad personal en un órgano de representación ya sea del nivel nacional o departamental o municipal, que se realiza durante una legislatura y que consiste en que un individuo, caracterizado como representante popular democráticamente elegido, no abandona su cargo; pero sí abandona la formación política en la que se encontraba para pasar a otra determinando, de este modo, un nuevo equilibrio en la mayoría gobernante. (Passarelli, 2011)

\subsubsection{Causas y Justificación del transfuguismo}

De acuerdo con Curreri, (2004), una de las causas jurídicas del transfuguismo es la mala interpretación que se le da al principio del libre mandato político contemplado en casi

\footnotetext{
${ }^{14}$ Que sigue siendo el sujeto activo, incluso de la financiación electoral.
} 
todas las Constituciones contemporáneas ${ }^{15}$, porque lo que se observa de común en varios países, como causa principal del transfuguismo, es la inconsistente institucionalización del sistema de partidos que presenta organizaciones con poco arraigo de los ideales del partido del que era miembro, además de presentar una organización social relativa (conveniente).

Estas causas, generalmente, son vistas bajo el interés particular que busca intereses particulares, comportamiento que ha sido considerado, por algunos sectores, como traición que hace que la ruptura muchas veces se realice con posturas violentas entre el trásfuga y los dirigentes del partido, quienes no reconocen la fragilidad institucional en una bancada que no tiene relación política ni ideológica con el partido que los llevó a la representación.

Así se ve afectada la relación interna de los partidos por el tipo de reglas electorales existentes y específicamente por el carácter proporcional o mayoritario del proceso electoral, como lo ha indicado Curreri (2004), quien además considera que, una de las causas jurídicas del transfuguismo, es la presencia de reglas proporcionales que dan lugar a formas de gobierno débiles y con mayoría parlamentaria inestable.

Por su lado, Colomer, (1990) señala que pueden ser muchas las motivaciones personales que inducen a los políticos a comportamientos tránsfugas, entre las cuales indica que son que hay interés por optimizar sus perspectivas, dado que acostumbran dejar grupos que, en su estima, les brindan reducidas garantías para desarrollar sus políticas predilectas, o para agilizar el acceso a cargos y/o para permitirles una reelección.

Las casusas reales de éste fenómeno están dadas a partir de la poca confianza jurídica con que se abordan los casos de transfuguismo, unida a la crisis de representación política, lo cual se evidencia a través de ciertas interpretaciones que se plantean en el ámbito jurídico,

\footnotetext{
${ }^{15}$ Así se explica, que una de las causas del transfuguismo se debe a la cobertura jurídica que se otorga a dicho fenómeno en muchas democracias actuales.
} 
CRISIS DE REPRESENTACIÓN COMO CONSECUENCIA DEL TRANSFUGUISMO POLÍTICO EN COLOMBIA

teniendo como resultado la permisividad de éste tipo de conductas, puesto que se puede analizar el comportamiento de los tránsfugas desde el punto de vista sociológico de su propia racionalidad y se acepta la consideración del fenómeno como traición: es así porque lo realiza un sujeto racional que se beneficia de la infraestructura de la organización, como de los recursos dedicados a la campaña electoral del partido al que representa en ese momento, asegurando, de ese modo, su elección.

De esta forma, se concibe el transfuguismo como un tipo de conducta política que conlleva a un acto de traición, el cual coloca el fenómeno de cara con los representados, dado que el partido, (fuera de una posible sanción social), no tiene la posibilidad de reclamar ese engaño después de obtener el trásfuga su escaño por mandato popular, supuestamente con votos de miembros del partido. (Porras, 1994, p. 45)

Analizado lo anterior, se hace necesario entender las justificaciones que pueden tener los sujetos políticos activos para que realicen el cambio de partido político, paso que argumentan en diversos sentidos así:

En primer lugar está la ideología de los partidos, que con el trascurrir del tiempo ha sufrido grandes transformaciones, conllevando en ciertos casos, incluso, al cambio de orientación reflejada en la práctica; actúa de forma diversa o aún de forma totalmente contraria, a la posición original por la cual el representante acudió a sus filas; por ello, el individuo practicante del transfuguismo, puede aducir como justificación valedera que el cambio de partido lo hizo motivado por la a innovación ideológica acogida por el partido y a la que no se somete por su propia convicción. En este caso, es el partido el que lo aleja de sus filas.

En segundo término está la posible crisis o desaparición de su partido, lo que obliga a sus integrantes a cambiar de organización y ubicarse en una similar a la que estaban militando, 
CRISIS DE REPRESENTACIÓN COMO CONSECUENCIA DEL TRANSFUGUISMO POLÍTICO EN COLOMBIA

justificación que de ser cierta, el partidario no tiene la calidad de tránsfuga, porque su comportamiento es la consecuencia de la crisis que se presenta al interior de los partidos, a no ser que, aprovechando dicha circunstancia, prefiera retirarse antes de ser vencido en el respectivo debate.

El tercer motivo es el oportunismo que les permite argumentar que se van porque tienen expectativas de mejores posiciones políticas en otra organización. Esta situación se da comúnmente cuando el militante percibe que en otro partido logra acceder al poder de forma más pronta, pero también, ésta motivación puede estar ligada a promesas económicas, dando paso inevitable a la corrupción.

El cuarto y último motivo es la divergencia que se presenta con el líder del partido al que se pertenece. Estas diferencias, en algunos casos, encubren rencillas personales y las tapan con justificaciones de tipo ideológico.

\subsubsection{Doble militancia y Transfuguismo político. Aproximaciones jurídicas}

Debemos considerar las sentencias C-342 de 2006, C453 de 2006 y C-477 de 2006, proferidas por la Corte Constitucional de nuestro País, que en su Ratio Decidendi, determinan el concepto de la doble militancia, al referenciar que existe prohibición Constitucional para que un ciudadano pueda pertenecer a más de un partido político; es decir, no puede ser miembro de partidos diferentes al mismo tiempo, prohibición igualmente consagrada en el Inciso $1^{\circ}$ del artículo 2 de la Ley 1475 de 2011, así: "En ningún caso se permitirá a los ciudadanos pertenecer simultáneamente a más de un partido o movimiento político”.

En Colombia existen cinco formas de doble militancia, reconocidas por la Constitución Nacional del 91 y por el Inciso $2^{\circ}$ del artículo $2^{\circ}$ de la Ley 1475 de 2011, al reglamentar la prohibición de la doble militancia, de acuerdo a la calidad del infractor, así: 
"Quienes se desempeñen en cargos de dirección, gobierno, administración o control, dentro de los partidos y movimientos políticos, o hayan sido o aspiren ser elegidos en cargos o corporaciones de elección popular, no podrán apoyar candidatos distintos a los inscritos por el partido o movimiento político al cual se encuentren afiliados. Los candidatos que resulten electos, siempre que fueren inscritos por un partido o movimiento político, deberán pertenecer al que los inscribió mientras ostenten la investidura o cargo, y si deciden presentarse a la siguiente elección por un partido o movimiento político distinto, deberán renunciar a la curul al menos doce (12) meses antes del primer día de inscripciones."

Igualmente en concordancia con el Inciso 12 del artículo 107 de la Constitución Política, en forma específica, consagra que: "Quien siendo miembro de una corporación pública decida presentarse a la siguiente elección, por un partido distinto, deberá renunciar a la curul al menos doce (12) meses antes del primer día de inscripciones".

Inciso $3^{\circ}$ del artículo $2^{\circ}$ de la Ley 1475 de 2011, dispone que:

"Los directivos de los partidos y movimientos políticos que aspiren ser elegidos en cargos o corporaciones de elección popular por otro partido o movimientos políticos o grupo significativo de ciudadanos, o formar parte de los órganos de dirección de estas, deben renunciar al cargo doce (12) meses antes de postularse o aceptar la nueva designación o ser inscritos como candidatos" 
Inciso $5^{\circ}$ del artículo 107 de la Constitución Política de 1991, se refiere a forma específica dirigida a los candidatos: "Quién participe en las consultas de un partido o movimiento político o en consultas interpartidistas, no podrá inscribirse por otro en el mismo proceso electoral".

Así es que la doble militancia tiene justificación en las consecuencias que genera el transfuguismo en el sistema democrático, debido a que se trata de una práctica censurable, en la que en ocasiones caen los políticos que profesan cargos de representación pública, y que de esta forma, afectan a los ciudadanos en general al establecerse un engaño a las preferencias electorales por las cuales fue electo, debilitando la legitimidad tanto en las elecciones de los candidatos que se cambian de partido una vez elegidos (tránsfugas), como en las normas políticas y jurídicas que se tracen en el transcurso de consenso y de toma de decisiones, que efectúan los cuerpos colegiados de elección popular donde, esta prohibición, resulta de gran importancia.

Por medio de diversas normas, Colombia ha pretendido rectificar esas secuelas que actualmente reglamentan la doble militancia. De esa forma, es como se le dio el arranque normativo a la prohibición del transfuguismo por medio del Acto Legislativo 01 de 2003, o la llamada reforma política del mismo año; aunque ésta norma escasamente alcanzó un carácter general debido a que hizo falta que se indicara de forma explícita los aspectos específicos en que incurre la conducta prohibida, al igual las formas de sanción que se aplicarían a quien desconociera el mandato constitucional.

Se incluyó a la prohibición de la doble militancia, el deber de renunciar a la curul o cargo 12 meses antes de la inscripción de la candidatura, a los representantes elegidos por voto popular que pretendieran presentarse a próximas elecciones por un partido diferente al que les dio su aval. 
CRISIS DE REPRESENTACIÓN COMO CONSECUENCIA DEL TRANSFUGUISMO POLÍTICO EN COLOMBIA

Éste acto legislativo conformó la primera aproximación jurídica a la problemática de la doble militancia, toda vez que prohibió de forma expresa la conducta y actuación de los tránsfugas políticos al consagrar la prohibición a los ciudadanos de pertenecer de forma paralela a más de un partido político.

Luego se expidió la Ley 794 de 2005, denominada la Ley de Bancadas, que reguló algunos aspectos relacionados con la doble militancia, entre ellos, confirió la facultad a los partidos de condenar las conductas desleales de los miembros electos, para que actúen de forma racional en los partidos políticos y sus espacios.

Posteriormente, la Ley 1437 de 2011 o Código de Procedimiento Administrativo y de lo Contencioso Administrativo, consagró causal de nulidad electoral a los candidatos que incurran en doble militancia y, finalmente la Ley 1475 de 2011, consagró la revocatoria de la inscripción para el candidato que infrinja la proscripción constitucional de militar en dos o más partidos de manera simultánea.

Se desprende de lo anterior, que en principio el transfuguismo fue consagrado como una prohibición constitucional, sin sanción jurídica real, por lo que el Consejo de Estado consideró que, si bien la conducta se encontraba proscrita por la Constitución, la misma no era sancionable por vía judicial ya que transfería esa potestad a los partidos políticos por medio de sus reglamentos internos, cuando comprobaran la infracción en uno o varios de sus militantes.

Posteriormente las leyes 1437 y 1475, ambas del año 2011, que establecen sanciones a la doble militancia, en principio, sólo se consideraron aplicables para la que se refería a la que se presenta durante el proceso electoral inicial; sin embargo, el Consejo de Estado, desde principios de 2013, cambio de postura y reconoce que la doble militancia política, si configura causal de nulidad de la elección del candidato que incurra en ella, aunque falta 
CRISIS DE REPRESENTACIÓN COMO CONSECUENCIA DEL TRANSFUGUISMO POLÍTICO EN COLOMBIA

pronunciamiento sobre la sanción a ésta conducta antidemocrática cuando sea un representante político en ejercicio de sus funciones.

Quien la cometa, por ende, aún continúa sin sanción jurídica eficaz la doble militancia que se presenta en el ejercicio del cargo de elección popular en las diferentes corporaciones públicas; es decir, en la que incurre el político, no como candidato, sino como representante electo, siendo ésta la que más afecta el principio de representación política de los ciudadanos, fundamento del régimen democrático.

Es claro, entonces, que la doble militancia política inicial, esto es, la que surge durante el proceso electoral; actualmente tiene contempladas las sanciones jurídicas de declaratoria de nulidad del acto de elección y de revocatoria de la inscripción de la candidatura y que, la sanción a ésta conducta prohibida, frente a la doble militancia política sobreviniente; es decir, la que se presenta durante el ejercicio del cargo de elección popular; sigue siendo potestad de los partidos y movimientos políticos por así disponerlo la Ley 1475 de 2011 al establecer que, los estatutos de tales colectividades deben contener un régimen disciplinario interno que prevea una penalidad a la doble militancia de sus miembros, norma que sigue siendo ineficaz por cuanto por falta de voluntad política. Así las cosas, no hay mecanismo de control a dicha práctica, que como se ha analizado, es nociva para el fortalecimiento sistema político.

De lo anteriormente expuesto se puede deducir que no existe una ley específica que sancione el fenómeno del transfuguismo; sino que debe recurrirse por analogía a la misma constitución y leyes como las enunciadas, emanadas para tipificar conductas similares que nos permitan concluir que, el transfuguismo político, puede ser considerado como un problema de representación en el sentido jurídico porque este mismo fenómeno se encuentra inmerso en una relación política en cuanto a la legitimidad como identificación doctrinaria de los partidos. 
CRISIS DE REPRESENTACIÓN COMO CONSECUENCIA DEL TRANSFUGUISMO POLÍTICO EN COLOMBIA

En términos de Sartori (2004), todo parece indicar que el rol de la justicia se limita a custodiar el principio de representación únicamente en su sentido jurídico. El trabajo de las cortes, de acuerdo a lo anterior, consiste entonces en considerar que ese vínculo de mandato está conforme de manera válida al ordenamiento jurídico, como lo indica Cuéllar (2012):

Esta cuestión, inherente a la naturaleza jurídica o extrajurídica del problema del transfuguismo, resulta también de sustancial relevancia al momento de proponer soluciones legislativas para el mismo. En efecto, sería válido sostener que una legislación específica en la materia aportaría una solución adecuada, siempre y cuando operemos bajo la hipótesis de que el problema es esencialmente jurídico. Por el contrario, si consideramos que el problema resulta estrictamente sociológico, en cuanto a la identificación subjetiva entre el ciudadano y su representante, y de legitimidad en términos de creencia política, resulta claro que la cuestión del transfuguismo no constituye -o no debería constituir- materia objeto de legislación. (p. 76)

Es en ese sentido, el rol que la Constitución y la ley deben atribuir a los partidos políticos para los fines de la representación, no es otro que determinar las conductas asociadas al transfuguismo político y situarlas en un campo compuesto de normas y principios inmersos en la Constitución y leyes de la república, por lo que, sobre éste aspecto debe adicionarse lo consagrado en el artículo 38 de la Constitución Nacional y al artículo 2 de la Ley orgánica de los partidos políticos que, al asignar un rol superior al partido político para que conformen una representación mediante el monopolio en la postulación de candidatos, éste sea armónico con el principio constitucional de representación contenido en el artículo primero, que dispone: 
CRISIS DE REPRESENTACIÓN COMO CONSECUENCIA DEL TRANSFUGUISMO POLÍTICO EN COLOMBIA

"Una adecuada armonización de estas cláusulas constitucionales y legales permite cuestionar, con razón, la validez de una representación parlamentaria que no guarde correlación con partido político alguno, y no sólo en términos políticos, sino también constitucionales" (Perícola \& Linares, 2014, p. 240). A partir de allí, es que a criterio propio se pueden establecer los elementos constitucionales y jurídicos del transfuguismo y sus sanciones.

\subsection{Sistema de Partidos en Latinoamérica.}

\subsubsection{Cambios en la representación de los partidos: "Sistema de partidos en Chile}

\section{y México".}

Desde que inició nuevamente la democracia en Chile, el poder político ha pasado del gobierno de la Concertación a otro con partidos de oposición existiendo una fisura entre la ciudadanía, el gobierno y la clase política que cada vez es más grande, todas vez que a las autoridades emergentes les ha faltado canales institucionales eficaces de comunicación hacia la ciudadanía para fomentar los partidos de su propio sector por carecer de capacidad de conversación política.

Esto debido a que, la gran mayoría de las veces, es rechazada por un protagonismo presidencial que ha originado un desprestigio de la política y de sus dirigentes políticos que demuestran una incapacidad por modernizar las instituciones y prácticas políticas, en miras asegurar la democratización interna y consolidación de los partidos y de sus líderes.

Estos no sólo han limitado las opciones al liderazgo juvenil; sino que cada vez demuestran menos interés de interrelacionarse con una ciudadanía que encara nuevos desafíos en un mundo globalizado, realidad confirmada por las varias encuestas efectuadas en Chile a la opinión pública que, como resultado, señalaron la crisis de los partidos, del sistema de 
partidos y de su representación democrática, la cual es alarmante en relación con otros países del medio circundante.

Por intermedio de esas mismas encuestas en el pasado, se evidenciaban apoyos a los diferentes partidos del 30 o 40\% según datos de Valenzuela, (2003), teniendo índices hasta de un $70 \%$ donde la población se identificaba con la izquierda y la derecha del país y, como se mencionó, es bastante preocupante que hoy en día, cualquiera que sea el método de medición en Chile, la suma de todos los partidos goza de una identificación partidaria de menos del $40 \%$, además existe a la par un descenso respecto de la satisfacción con la democracia, en una baja del $56 \%$ al $32 \%$ entre 2010 y 2011 , por debajo de la media Latinoamericana ${ }^{16}$.

Es decir, en la actualidad es una minoría de chilenos los que siguen creyendo y apostando por la democracia; esto concuerda con un diagnóstico de que en Chile la democracia favorece a unos pocos mostrando una falencia de justicia social, lo que ha hecho emerger movimientos sociales que expresan su descontento tanto con el gobierno como con la forma de gobernar; aunque hoy en día la oposición cuenta con tanta desvalorización como el gobierno.

Para afrontar la crisis de representación en Chile, Valenzuela (2003) indica que se debe terminar el sistema binominal para volver a un sistema electoral proporcionado, reforma que es la más indicada para garantizar mayores niveles de representatividad y competencia política al tiempo que contribuye a fortalecer la coherencia institucional de los partidos y su disciplina interna.

El nuevo sistema electoral, planteado por el mismo sistema militar anterior, asumió un gran objetivo que fue cambiar el sistema de partidos a un bipartidismo moderado, además

\footnotetext{
${ }^{16}$ Encuesta de la Corporación Latinobarómetro 2011.
} 
CRISIS DE REPRESENTACIÓN COMO CONSECUENCIA DEL TRANSFUGUISMO POLÍTICO EN COLOMBIA

de avalar que la derecha, (que apoyó al gobierno militar de la época), pudiera ostentar una representación parlamentaria paritaria. Este propósito al final no se logró.

En un país como Chile, con una larga trayectoria multipartidista, un cambio en el sistema electoral no cambia el sistema de partidos, los partidos simplemente se adaptan a la ley hasta que tengan la oportunidad de nuevamente cambiarla. (Lijphart, 1990).

Es posible que el sistema binominal en Chile haya favorecido la disciplina para la moderación de la política, de lo que si no cabe duda, es que ese mismo sistema estimuló una política vertical donde un conjunto de directores políticos, de ambos partidos políticos, disponían quién iba a ser el candidatos y a quiénes representaría lo que socavó el intento de tener un proceso electoral transparente.

Aunque el reglamento de los partidos contiene medidas que incentivan la participación y la democracia interna, visiblemente, en la práctica, no es así y la ley no regula bien la disposición constitucional.

Por otro lado, en México, la clasificación del sistema de partidos está dada en un sistema de partido hegemónico, predominante y de pluralismo moderado (González, 2006). El primero, Sartori (2002) lo infiere como la segunda distinción del partido hegemónico y pragmático, el cual, explica diciendo que, en dicho país, existe "un caso claro de partido hegemónico que permite partidos de segunda clase, y en la medida en que, sigan siendo lo que son” (p. 283).

El Partido Nacional Revolucionario (PNR) fue fundado en los inicios del año 1929, buscando estabilizar al país y normalizar el acceso al poder de los veteranos de la guerra civil y cuando a él se incorporaron las centrales obreras y campesinas, cambió su nombre por el de Partido de la Revolución Mexicana (PRM), el que en 1946, (cuando el partido lo encabezaron las instituciones sociales que emergieron a partir de la guerra civil del país), volvió a cambiar 
CRISIS DE REPRESENTACIÓN COMO CONSECUENCIA DEL TRANSFUGUISMO POLÍTICO EN COLOMBIA

su nombre por el que existe actualmente; Partido Revolucionario Institucional (PRI), siendo el partido Oficial hasta el año 2000. (Carpizo \& Madrazo, 2014.).

Así las cosas, dentro del sistema que se ejercía en México, era el presidente el único líder del partido; Carbonell (2002) afirmó que:

"El jefe nato del Partido oficial y de la clase política en su conjunto [...] el Presidente es el árbitro indiscutido de los conflictos que se producen entre las fuerzas que participan en la contienda política. Así mismo, controla de forma indirecta, a través del partido, a las grandes organizaciones de masas, las cuales son las encargadas de darle sustento y brindar apoyo tanto al partido como al sistema político en su conjunto (...)”( (p. 59).

Para 1968 existió el movimiento estudiantil importante por su arenga ideológica originando transformaciones reales al sistema político mexicano. Pasaron veinte años más para que viniera otro movimiento político e hiciera mover al sistema de partidos, en elecciones de 1988, hubo una ruptura ideológica que revolucionó al PRI, y se formó el nuevo Partido Frente Cardenista de Reconstrucción Nacional, luego llamado Partido de la Revolución Democrática (PRD).

A partir de ahí, se comenzaron a dar transformaciones sustanciales las cuales han ido evolucionando e interactuando con diversos movimientos dándole un giro de actualidad y globalización a la política, debido a la generación de grandes demandas de la sociedad civil. Éstas exigían del gobierno una labor eficiente que comenzara a complacer sus diversas demandas; la transformación de México ha sido lenta en comparación con la mayoría de países latinoamericanos. 
CRISIS DE REPRESENTACIÓN COMO CONSECUENCIA DEL TRANSFUGUISMO POLÍTICO EN COLOMBIA

El caso de México es, de algún modo, un sistema de partidos institucionalizado aunque nuevo haciendo que converja en un estilo democrático; pero para llegar a ello, deben partir la relación existente entre el partido hegemónico y el Estado. México está evolucionando con base en sistemas de partidos hegemónicos autoritarios, y le hace falta llegar a una institucionalización de sistemas competitivos de partidos que se vislumbra llegará porque se fortalece el nuevo sistema de partidos, como consecuencia de la aparición de una verdadera competencia política.

\subsubsection{Cambios en la representación de los partidos: "Sistema de partidos en} Colombia"

Hoy por hoy, hay en el entorno político pérdida de credibilidad y desconfianza por parte de los ciudadanos hacia los partidos políticos, a los candidatos a cargo de elección popular y a los dirigentes en general; por diversidad de situaciones que dan origen a la crisis del sistema de partidos que se despliegan en un ambiente viciado y reflejado en el porcentaje de abstención electoral, demostrando el debilitamiento de la representación política dentro de la importancia pública.

En Colombia, el sistema de partidos, tiene una combinación entre partidos y movimientos políticos cobijados por el mismo tipo de personería jurídica que les otorga igualdad de derechos y garantías, deberes y obligaciones y ausencia de privilegios. Independientemente del tamaño, origen, desarrollo e intereses que representan; los partidos y movimientos son considerados como organizaciones políticas iguales. 
Añadido a esto, en la competencia electoral, existen los grupos significativos de ciudadanos y de organizaciones, más sociales que políticas, con derecho a postular candidatos ante los electores, para que sean elegidos como sus representantes ante las diferentes instituciones del estado. El sistema de partidos se asimila a uno de esos aparatos políticos y electorales con responsabilidades imprecisas ante el mismo; pero su importancia va más allá del número de unidades, ya que descansa en la situación mediadora y de representación de intereses sociales que cada unidad dice representar.

Asimismo, el "sistema está integrado por expresiones de carácter nacional, no territoriales o geográficamente adscritas, ni por minorías étnicas y políticas jurídicamente reconocidas como no nacionales lo cual se vivió entre 1991 a 2011” (Fundación Konrad Adenauer-KAS-Colombia, 2014, p. 74). No obstante, algunas expresiones políticas ideológicamente no mayoritarias ni nacionales que logran escaños en el Legislativo, quedan habilitadas para postular candidatos en todos los eventos electorales.

Con la Constitución de 1991 el sistema de partidos dejó de ser bipartidista y pasó a ser multipartidista, sin antecedentes en otros países, generó tal aumento de movimientos y partidos totalmente fraccionados, que esparcieron tanta confusión en los electores que, la clase política del legislativo, se vio obligada a proferir los actos legislativos 01 de 2003 y 01 de 2009; normas electorales y de partidos que fueron, con su aplicación, comprometiendo un nuevo proceso de reagrupamiento del sistema de partidos que sirvió de marco institucional para el fortalecimiento y la modernización de la política partidista pero que no atendió al tipo de partidos que se requería en la sociedad y se omitió la calidad de los mismos.

Las reformas, se encaminaron a la lista única; al umbral y a la financiación de los partidos; se prohibió, (como anteriormente se analizó), la doble militancia por medio de la inclusión en el artículo 107 de la Constitución del 91, del siguiente parágrafo: “en ningún caso 
se permitirá a los ciudadanos pertenecer simultáneamente a más de un partido o movimiento político con personería jurídica" (Constitución Política de Colombia, 2014).

La desaparición de líderes, el fraccionalismo y la indisciplina que ha sido marcada en los partidos colombianos, se denota en la lejanía que los dirigentes políticos tienen de las estructuras de los mismos y el desinterés en aplicar sus principios y doctrinas, así alejan al elector debido a que sus demandas no son atendidas respecto a la necesidad de practicar democracia al interior de los partidos. Esto conduce a que la sociedad, dentro del entorno político en que se desenvuelve, desarrolle una directriz conducente a que los partidos se reglamenten desde la misma normatividad.

Así como lo afirma la (Fundación Konrad Adenauer-KAS-Colombia, 2014) ${ }^{76}$,

"las fracciones de expresión nacional se dispersan aún más en lo local. A ello se suma la variedad de movimientos y partidos sin personería jurídica que existe especialmente en lo local, algunos de los cuales no logran configurarse o estructurarse nacionalmente". (p. 49)

Actualmente como ejemplo podemos citar; el Partido Verde que tiene su electorado fuerte en Bogotá y en unos municipios más, en el Sur del país está Cali con su movimiento Podemos Cali, guiado por Jorge I. Ospina el cual no ha logrado traspasar los límites de la ciudad; en Antioquia está el movimiento Compromiso Ciudadano por Colombia, con el Dr. Sergio Fajardo a la cabeza, sin que tampoco haya logrado consolidarse nacionalmente.

El esquema de un sistema nacional de partidos, moderadamente agrupado, funciona tanto política como electoralmente de forma fraccionada, y en ello muchos dirigentes transitan de un partido a un grupo significativo de ciudadanos y luego cambian a otro partido, o se 
CRISIS DE REPRESENTACIÓN COMO CONSECUENCIA DEL TRANSFUGUISMO POLÍTICO EN COLOMBIA

devuelven al partido de origen, sin más requisitos que su propia voluntad. Ejemplo de ello es el Dr. Álvaro Uribe Vélez quien fue miembro del partido liberal, para luego ser cofundador del Partido de la U y finalmente fundar el Movimiento que denominó: El Centro Democrático.

En las siguientes tablas se observan, vigentes al año 2014, trece partidos políticos; sin embargo la composición del Congreso tiene a 14 partidos o movimientos representados, resaltando que, de los llamados minoritarios, sólo el grupo ASI, cuenta con curules tanto en cámara como en Senado, porque los otros pequeños grupos solo tienen curules bien en el Senado o bien en la Cámara de Representantes.

\begin{tabular}{|l|}
\hline Partido Liberal Colombiano \\
\hline Partido Conservador Colombiano \\
\hline Movimiento de Inclusión y Oportunidades MIO \\
\hline Afrovides \\
\hline Movimiento Autoridades Indígenas de Colombia, AICO \\
\hline $\begin{array}{l}\text { Movimiento Alianza Social Independiente, ASI } \\
\text { (antiguo Movimiento Alianza Social Indígena) }\end{array}$ \\
\hline Partido Alianza Verde (antiguo Partido Verde) \\
\hline Partido Social de la Unidad Nacional U \\
\hline Partido Cambio Radical Colombiano \\
\hline Partido Polo Democrático Alternativo \\
\hline $\begin{array}{l}\text { Partido Opción Ciudadana } \\
\text { (antiguo Partido de Integración Nacional, PIN) }\end{array}$ \\
\hline Movimiento MIRA \\
\hline Partido Unión Patriótica \\
\hline
\end{tabular}

Tabla 3. Partidos Políticos con personería jurídica vigente en Colombia (2010-2014) 


\begin{tabular}{|lcc|}
\hline \multicolumn{1}{|c|}{ Agrupación Política } & $\begin{array}{c}\text { Escaños en } \\
\text { Cámara de } \\
\text { Representantes }\end{array}$ & Escaños en Senado \\
\hline Partido Social de la Unidad Nacional, De la U & 47 & 28 \\
Partido Conservador Colombiano & 37 & 22 \\
Partido Liberal Colombiano & 36 & 17 \\
Partido de Integración Nacional, PIN (hoy Opción Ciudadana) & 12 & 9 \\
Partido Cambio Radical & 16 & 8 \\
Partido Democrático Alternativo, PDA & 5 & 8 \\
Partido Verde & 3 & 5 \\
Movimiento Independiente de Renovación Absoluta, MIRA & 1 & 3 \\
Movimiento de Integración Regional & 1 & 0 \\
Movimiento Popular Unido & 1 & 0 \\
Movimiento de Apertura Liberal & 3 & 0 \\
Movimiento de Alternativa de Avanzada Social, ALAS & 1 & 0 \\
Otros partidos o movimiento de minorías étnicas (1 curul en la & 3 & 0 \\
Cámara por cada movimiento: ASI, Afrovides y MIO) & 0 & 2 \\
Otros partidos o movimientos (1 curul en el Senado por cada & 0 & \\
movimiento: ASI y AICO) & 1 & \\
\hline
\end{tabular}

Tabla 4. Partidos y movimientos políticos con escaños en Congreso (2010-2014)

Fuente: (Fundación Konrad Adenauer-KAS-Colombia 2014, p. 26)

Para que se empiecen a eliminar los problemas existentes y para que las organizaciones políticas cimenten su representación, se debe facilitar la construcción de una cultura política democrática basada en la inclusión, la confianza, la participación y el compromiso, para que se minimicen, mientras se logran erradicar, los grados de corrupción actualmente existentes.

De igual forma, el sistema de partidos se basa en el reconocimiento de colectividades nacionales por medio de mayorías y no se reconoce la existencia de partidos territoriales o geográficos, salvo los que promueven los partidos institucionalizados, como la representación en el extranjero y/o los movimientos étnicos como el de negritudes e indígenas.

Por otro lado, no hay facilidad para que grupos significativos de ciudadanos sean reconocidos socialmente como movimientos políticos, además, los partidos y movimientos políticos que si cuentan con personería jurídica, aparte de que los ignoran, los acusan constantemente de convertirse en trampolines electorales. De esta forma, en Colombia, el 
sistema de partidos podría estar ingresando en una fase de disolución después de décadas de gran estabilidad.

En Colombia, los partidos existentes se encuentran divididos por bandos o grupos segmentados que salen de sistemas electorales que permiten rivalidades entre las mismas facciones partidistas. El evidente faccionalismo ha sido una expresión del desgaste de las instituciones partidistas en los últimos tiempos. Las facciones suelen tener sus propios candidatos, generando la pérdida de la intervención organizacional en la selección de quienes deben llevar la representación que, definitivamente, individualizan la composición de las listas, con el fenómeno del voto preferente, que en la realidad confunde al elector.

Como resultado se da una gran cantidad de voto nulo o de voto en blanco, amén de mantener una gran abstención, especialmente en la juventud que se ha vuelto apática a toda actividad política, distinta a la que realiza en las universidades públicas como reacción, no al sistema de partidos; sino a toda autoridad legítimamente constituida, problemática que no concierne a este trabajo.

Los métodos de trasformación y permanencia política, de acuerdo con Alcántara (1997), corroboraran la creencia de que "la institucionalización de la política es cosa de un día, y los partidos la institución adecuada para esto" (p. 14), configurando la crisis de representación de los partidos, como organizaciones o instituciones vitales en la vida electoral y que se fundamenta en el rechazo de los electores.

De acuerdo a lo plasmado por Corporación Latinobarómetro (2011), los sistemas de partidos en América Latina están pasando por un abandono masivo en la mayoría de sus países.

“(...)A través de las elecciones los ciudadanos han logrado desmantelar todas las viejas élites, reemplazándolas en muchos casos por élites nuevas, inexpertas en el 
arte de gobernar. Eso ya sucedió, ahora se entra en otra etapa que es desmantelar el sistema de partidos, lo que es mucho más complejo que reemplazar una élite por otra. Al no sentirse los ciudadanos representados por el sistema de partidos, se produce una dispersión en muchos casos mucho más allá de lo razonable de los grupos que intentan representar, que lejos de ser un síntoma de anarquía, es un síntoma de demanda democrática y de cambios por la vía de las reformas y no de la revolución. [...] Como dijo el Presidente Sarkozy después del desastre de Lehman, Brothers, que desató la última crisis económica mundial; la que todavía estamos sufriendo, el mundo necesita cambiar los indicadores con los cuales observa su evolución, porque claramente esos indicadores no nos están dando la información que necesitamos para saber lo que pasa. Exactamente, el mundo se mide así mismo con indicadores que no nos dicen muy bien lo que pasa. El caso de Chile cae en esas categorías, los indicadores observables indicaban que todo iba bien, muy bien. Otras informaciones nos indicaban que había grandes vacíos por abordar, sin que nadie les hubiera dado el peso que deberían haber tenido. Los movimientos ciudadanos del 2011 nos muestran la magnitud de lo acumulado y de lo invisible en los indicadores. Pero Chile no es el único caso. Perú lo mostró también en las elecciones presidenciales del 2011, las demandas silenciosas acumuladas eligieron un candidato extramuros del sistema de partidos, que recogió las demandas sin estadísticas globalizadas ni atendidas por la comunidad internacional. La discrepancia, la incongruencia entre la visión que el mundo occidental tiene de los procesos en los países y lo que la población piensa de sus propias vidas, queda reflejado en los indicadores de Latinobarómetro que vienen desde hace 16 años señalando las grandes quejas de las poblaciones de nuestras 
CRISIS DE REPRESENTACIÓN COMO CONSECUENCIA DEL TRANSFUGUISMO POLÍTICO EN

sociedades y donde lentamente éstas están saliendo a la superficie produciendo cambios políticos, sociales y económicos en la región. [...] Los movimientos ciudadanos del 2011 nos muestran la magnitud de lo acumulado y de lo invisible en los indicadores(...)" (Corporación Latinobarómetro, 2011, pp. 6-8)

Aceptada por los gobiernos, la decadencia del sistema de partidos, los presidentes del continente americano ha resuelto concebir coaliciones con otros partidos, de muy distinta ideología, para permitir su dirección gubernamental.

Por lo anterior, la merma gradual en la proporción de gobiernos unipartidista genera la creación paralela de gobiernos amparados por coaliciones, generando una promiscuidad ideológica que, igualmente, lleva al elector a decir que da lo mismo votar por uno u otro partido debido a que, al final, el que sale triunfador en aras de la unidad nacional da participación al, o a los, que derrotó y muchos, complacidos aceptan. Lastimosamente lo hacen sólo para repartirse el ponqué, (como se dice en los círculos populares), en abierto contubernio, no sólo entre autoridades legislativas, ejecutivas y jurisdiccionales; sino entre quienes deben ejercer los diferentes controles sobre ellos, como la fiscalía, la Procuraduría y la Contraloría, por citar algunos.

En síntesis, Colombia, al igual que los países democráticos de América Latina, se encuentra entre los países incursos en grandes dificultades institucionales que afectan la gobernabilidad, la solidez política y el Estado Social de Derecho, así como la libertad y el vínculo que debe existir entre sus propios órganos. Hoy cada cual reclama el poder, desde su posición, producto de la actividad de los sistemas electorales y del sistema de partidos que redunda, a su vez, en graves problemas de inseguridad que transforman al cono sur en una región ostensiblemente violenta. 
En Latinoamérica, los partidos y sus sistemas se caracterizan más por intentar ajustar y clasificar la realidad a sus funciones, que en atender a la misma para constituir prácticas políticas del día a día, porque estos prefieren ajustarlas para su propia supervivencia en el y por el poder. Es decir, se mantienen más en manifestar en qué forma desde sus inicios viven diariamente los partidos, indicando cómo han diseñado sus organizaciones y qué estructuras han mantenido para el logro de su supervivencia dentro del sistema; que en generar procesos de institucionalización, intermediación y profesionalización del actuar político dentro de procesos democráticos de inserción.

En los países comparados en esta investigación, Chile y Colombia cuentan con sistemas de partidos contendores ya institucionalizados, mientras México, cuenta con una supremacía hegemónica en actual transformación (Scully \& Mainwaring, 1997).

Para que se afiance la democracia, la institucionalización del sistema de partidos hace que su proceso sea importante, así como lo sustentan Scully y Mainwaring (1997), "si existe o no un sistema de partidos institucionalizado marca una honda diferencia en el funcionamiento de la política democrática" (p. 93).

Los sistemas de partidos moldean las perspectivas para el surgimiento de una democracia estable, que sea otorgada con legitimidad y que, a su vez, cuente con una política efectiva como resultado final.

Los partidos políticos se convierten en actores fundamentales, los cuales participan principalmente en el acceso al poder gubernamental por intermedio de elecciones abiertas convirtiéndose esto, en el proceso vital en el establecimiento de quién gobierna.

Tomando como ejemplo el índice de volatilidad electoral de Pedersen citado por Scully \& Mainwaring, (1997) establecido dentro del mismo periodo de los tres países en 
CRISIS DE REPRESENTACIÓN COMO CONSECUENCIA DEL TRANSFUGUISMO POLÍTICO EN COLOMBIA

estudio Chile, Colombia y México, se observa como el sistema de partidos en éstos países muestran su estabilidad dentro de elecciones legislativas y presidenciales, así:

\begin{tabular}{|l|c|c|c|c|c|c|c|}
\hline \multirow{3}{*}{ País } & \multicolumn{3}{|c|}{ ELECCIONES LEGISLATIVAS } & \multicolumn{3}{c|}{ ELECCIONES PRESIDENCIALES } & \multirow{2}{*}{ A + B / 2} \\
\cline { 2 - 7 } & PROMFDIO NÚMERO DEVOLATILIDAD & \multicolumn{2}{c|}{ PROMEDIO NÚMERO DE VOLATILIDAD } & \\
\cline { 2 - 7 } & Período & Per. Eectoral & Variable A & Período & Per. Eectoral & Variable B & \\
\hline Colombia & $1970-1990$ & 5 & 8,5 & $1970-1990$ & 5 & 10,9 & 9,7 \\
\hline Chile & $1969-1989$ & 2 & 17,5 & $1970-1989$ & 1 & 15,4 & 16,5 \\
\hline México & $1982-1991$ & 3 & 22,4 & $1982-1988$ & 1 & 32,2 & 27,3 \\
\hline
\end{tabular}

Tabla 5. Volatilidad Electoral Colombia, Chile, México

Fuente: Elaboración propia, a partir de datos tomados de: (Scully \& Mainwaring 1997, La institucionalización de los sistemas de partido en la América Latina)

Esta Tabla es realizada con base en la participación de votos (bancas) en períodos electorales individuales. De todos los partidos en la misma elección, nos muestra como Colombia arroja el índice extremo del más bajo, mientras que Chile ocupa un rango bajo y México está en la escala intermedia.

Igualmente, se puede observar que las votaciones en Colombia y México son más notables para las presidenciales mientras que, en Chile, el número de votantes es mayor en las elecciones legislativas. Del mismo modo, así como lo manifiestan Scully \& Mainwaring (1997), los modelos de competencia entre partidos en Colombia son bastante estables, en Chile prudentemente estables y en México muy inestables

Chile y México tienen partidos institucionalizados en los que las élites políticas son leales a sus partidos y la conducta del partido en el poder legislativo es sólida. Los partidos están bien organizados y, aunque están centralizados, tienen presencia en los niveles locales 
CRISIS DE REPRESENTACIÓN COMO CONSECUENCIA DEL TRANSFUGUISMO POLÍTICO EN COLOMBIA

del poder así como en el nacional que, en principio, podría decirse que el "trasfuguismo", de existir, no afectaría a los partidos.

Sin embargo la falta de rotación del liderazgo que lleva a permanentes pugnas en busca de renovación, cierran dichos caminos y, por ello, la separación es cada vez más frecuente en busca de nuevas oportunidades vistas en otros movimientos, no sólo políticos sino eminentemente gremiales, que afectan los sistemas de partidos que institucionalizados aportan a la gobernabilidad.

Así la unión entre el ejecutivo, el legislativo y los directores partidistas son más fuertes que en casos de sistemas de partidos primitivos; la experiencia indica que cuando existen democracias con sistemas de partidos institucionalizados, los partidos establecen las preferencias políticas del momento.

Un sistema de partidos institucionalizado no asegura en modo alguno a los gobiernos el apoyo del legislativo; pero aumenta su probabilidad para su éxito y por tanto, al debilitarse con la salida de algunos de sus líderes sufriendo el trasfuguismo, se menoscaba la anterior efectividad política, de ahí que, los sistemas de partidos en América Latina, en el transcurso de sus transformaciones, han entrado en niveles de grandes competencias surgiendo, de este modo, fuerzas políticas externas que además de competir consiguen liderazgo dentro de la política a nivel nacional en cada país.

Por esto, se hace importante realizar una breve reseña del comportamiento en Latinoamérica sobre competencia y polarización en los sistemas de partidos, para determinar si es o no fuente del trasfuguismo político. 


\subsection{Polarización y competencia en los sistemas de partidos latinoamericanos}

Como ya se ha podido observar, la fragmentación de los sistemas de partidos ha servido como elemento de inestabilidad de los mismos, pero a la vez, se han encontrado sistemas de multipartidismo estables en el transcurso del tiempo. Por ello, se debe tomar en cuenta otro factor de inestabilidad como es la polarización en la que se pueda absorber el sistema partidista.

De acuerdo con Sartori (1994):

"en primer lugar, se referencia, como el grado de fragmentación de un sistema, no compone un indicador confiable en cuanto a su polarización, ya que algunos sistemas fragmentados evidencian grados de polarización similares a los de sistemas con fragmentación escasa. En segundo lugar, aquellos sistemas en los que los aparatos democráticos han funcionado respectivamente bien, a pesar de la fragmentación de sus sistemas de partidos, son también aquéllos caracterizados por un grado bajo o moderado de polarización"17 (pp. 414-415),

Igualmente, la posición espacial de los partidos resulta adecuada cuando se aumenta el número de partidos dentro del sistema, como lo indica Sartori (1994), al afirmar:

"(...) las percepciones posicionales son útiles y, a la postre, inevitables, cuando aumenta el número de partidos. y el espacio izquierda-derecha se va haciendo más

\footnotetext{
${ }^{17}$ En América Latina esta posibilidad parece adecuarse ya que cuenta con índices similares de polarización en sistemas más o menos fragmentados.
} 
CRISIS DE REPRESENTACIÓN COMO CONSECUENCIA DEL TRANSFUGUISMO POLÍTICO EN

apropiado, como un auténtico espacio configurador, según pasamos de un contexto pragmático a un contexto ideológico de la vida política(...)" (p. 416).

De acuerdo al estudio realizado por Alcántara, del Campo, \& Ramos, (2001) la polarización ideológica es prácticamente alta en algunos sistemas de partidos de Latinoamérica, pero la dividen en tres grandes grupos; los que demuestran una baja polarización ideológica,(entre ellos Colombia, Honduras y Paraguay); los que se encuentran en un rango medio, (en los que se encuentran Bolivia, Perú, Guatemala, Venezuela, Uruguay y México); y los de mayor polarización ideológica (en el que se ubican Chile, Nicaragua, Costa Rica, Argentina y El Salvador).

Según Sartori, citado por Alcántara, del Campo, \& Ramos, (2001), de acuerdo con los índices en América Latina, hay sistemas apenas fragmentados con índices de polarización altos como el caso de Nicaragua y sistemas fragmentados con poca polarización, es el caso de Ecuador. En el caso de Chile, la relación es que a una mayor fragmentación corresponde una mayor polarización y recíprocamente este fenómeno se da también en Paraguay y Honduras, mientras que, en otros sistemas, se mezcla una polarización media con grados moderados de fragmentación partidista como sucede en México, Guatemala, Uruguay, Perú y Venezuela.

En la segunda premisa, Sartori, hace referencia a que la estabilidad y el buen funcionamiento democrático coinciden con niveles de polarización bajos, evidenciándose en los países latinoamericanos con mayor estabilidad democrática a lo largo del tiempo, como el caso de Chile con un formato claramente multipartidista y el caso de Uruguay con un formato bipartidista ampliado.

De acuerdo a este estudio, se corrobora que la polarización más que el formato numérico de los sistemas de partidos latinoamericanos, es el que afecta a la viabilidad de los 
sistemas democráticos. Así como lo manifiesta Alcántara et al. en su estudio, la elevada fragmentación de un sistema de partidos dificulta el funcionamiento de la democracia, dando lugar a la existencia de la polarización. Por el contrario, si un sistema está con bajos grados de polarización, la democracia puede funcionar y por ende, el trasfuguismo de existir, no vulnera el sistema de partido aun cuando esté fragmentado, su estructura social sea segmentada y su cultura política sea heterogénea (Alcántara, del Campo, \& Ramos 2001, p. 19).

\subsection{Marco Jurídico, legal y constitucional de los partidos políticos en Chile, México y}

\section{Colombia}

Al presentar los países en estudio, conceptos diferentes en su legislación con respecto a los partidos políticos, partiremos del siguiente cuadro para analizarlas.

\begin{tabular}{|c|c|}
\hline País & Definición - Legislación \\
\hline CHILE & $\begin{array}{l}\text { Ley de Partidos Políticos. Artículo } 1^{\circ} \text {. Los partidos políticos son asociaciones voluntarias, } \\
\text { dotadas de personalidad jurídica, formadas por ciudadanos que comparten una mis ma doctrina } \\
\text { política de gobierno. }\end{array}$ \\
\hline COLOMBIA & $\begin{array}{l}\text { Estatuto Básico de los Partidos y Movimientos Políticos. Artículo } 2^{\circ} \text {. Definición. Los partidos } \\
\text { son instituciones permanentes que reflejan el pluralis mo político, promueven y encauzan la } \\
\text { participación de los ciudadanos y contribuyen a la formación y manifestación de la voluntad } \\
\text { popular, con el objeto de acceder al poder, a los cargos de elección popular y de influir en las } \\
\text { decisiones políticas y democráticas de la Nación. } \\
\text { Los movimientos políticos son asociaciones de ciudadanos constituidas libremente para influir } \\
\text { en la formación de la voluntad política o para participar en las elecciones. } \\
\text { Los partidos y movimientos políticos constituidos que hayan cumplido todos los requisitos } \\
\text { constitucionales y legales tendrán personería jurídica. }\end{array}$ \\
\hline MÉXICO & $\begin{array}{l}\text { Constitución Política. Artículo } 41^{\circ} \text {. I. Los partidos políticos son entidades de interés público; la } \\
\text { ley determinará las formas específicas de su intervención en el proceso electoral. } \\
\text { Tienen como fin promover la participación del pueblo en la vida democrática, contribuir a la } \\
\text { integración de la representación nacional y hacer posible el acceso de los ciudadanos al } \\
\text { ejercicio del poder público. }\end{array}$ \\
\hline
\end{tabular}

Tabla 6. Definición de Partido Político según la legislación 
De lo anterior, se pueden dar las siguientes funciones atribuidas a los partidos, de acuerdo a su base jurídica establecidas en sus constituciones y legislaciones y que recopilamos, así:

\begin{tabular}{|l|c|c|c|c|c|c|}
\hline \multirow{2}{*}{ PAís } & \multicolumn{6}{|c|}{ FUNCIONES PARTIDOS POLÍTICOS } \\
\cline { 2 - 7 } & Representación & Participación & $\begin{array}{c}\text { Competencia } \\
\text { Cargos } \\
\text { Públicos }\end{array}$ & $\begin{array}{c}\text { Formulación } \\
\text { de Políticas }\end{array}$ & $\begin{array}{c}\text { Formación y } \\
\text { socialización }\end{array}$ & $\begin{array}{c}\text { Vigilancia del } \\
\text { proceso } \\
\text { electoral }\end{array}$ \\
\hline Chile & - & - & $\mathrm{X}$ & $\mathrm{X}$ & $\mathrm{X}$ & - \\
\hline Colombia & - & $\mathrm{X}$ & $\mathrm{X}$ & $\mathrm{X}$ & $\mathrm{X}$ & - \\
\hline México & $\mathrm{X}$ & $\mathrm{X}$ & $\mathrm{X}$ & - & - & $\mathrm{X}$ \\
\hline
\end{tabular}

Tabla 7. Funciones partidos políticos de acuerdo a su legislación

Fuente: Elaboración propia, con base en información extraída de Zovatto D. (2011, p.160)

De lo observado, claramente tenemos que Chile y Colombia no tienen representación ni vigilancia sobre los procesos electorales porque la normatividad vigente hace referencia a que, los partidos políticos, tienen esas específicas funciones que acogen con cierta diligencia por intermedio de propios veedores, estos acreditan, oportunamente, las que se encuentran consagradas en la Constitución Política de cada país, y que son señaladas en el siguiente cuadro:

\begin{tabular}{|l|c|l|}
\hline \multicolumn{1}{|c|}{ PAís } & $\begin{array}{c}\text { Fecha de la } \\
\text { Constitución }\end{array}$ & \multicolumn{1}{|c|}{ Artículos } \\
\hline Chile & 1980 & 18, 19 inciso 15 \\
\hline Colombia & 1991 & Art. 40 inciso 3; artículos 107, 108, 109, 110, 111, 112. \\
\hline México & 1917 & $\begin{array}{l}\text { 41 I, II y III, 116 párrafo 2, fracción IV, incisos f, g y h. } \\
\text { 122, párrafo 6, apartado C, Base Primera, fracción V, } \\
\text { inciso f. }\end{array}$ \\
\hline
\end{tabular}

Tabla 8. Regulación de los partidos en la Constitución Política 
CRISIS DE REPRESENTACIÓN COMO CONSECUENCIA DEL TRANSFUGUISMO POLÍTICO EN COLOMBIA

En Colombia el tema de los partidos políticos se menciona de manera directa en 7 artículos de la Constitución Política de Colombia, ubicados en el título IV, capítulo III, en los que se incluye a la oposición cuando señala derechos de partidos que no están dentro del gobierno. Efectivamente, la Constitución dispone:

“(...)Del estatuto de la oposición, artículo 112: Los partidos y movimientos políticos que no participen en el Gobierno podrán ejercer libremente la función crítica frente a éste y plantear y desarrollar alternativas políticas. Para estos efectos, salvo las restricciones legales, se les garantizan los siguientes derechos de acceso a la información y a la documentación oficiales, de uso de los medios de comunicación social del Estado de acuerdo con la representación obtenida en las elecciones para Congreso inmediatamente anteriores; de réplica en los medios de comunicación del Estado, frente a tergiversaciones graves y evidentes o ataques públicos proferidos por altos funcionarios oficiales, y de participación en los organismos electorales. Los partidos y movimientos minoritarios tendrán derecho a participar en las mesas directivas de los cuerpos colegiados, según su representación en ellos. Una ley estatutaria regulará íntegramente la materia”(...) (Constitución Política de Colombia, 2014)

En cuanto a leyes especiales sobre partidos políticos, si bien específicamente no existen se puede por analogía aplicar, como se demuestra a continuación: 


\begin{tabular}{|c|l|}
\hline \multicolumn{1}{|c|}{ PAÍS } & \multicolumn{1}{c|}{ Ley especial } \\
\hline \multirow{5}{*}{ Chile } & $\begin{array}{l}\text { Ley 18.460, 1985. } \\
\text { Ley 18.556, 1986. Regula al Servicio Electoral y el padrón electoral. } \\
\text { Ley Orgánica sobre Transparencia, límite y control del gasto electoral, No 19884/03. } \\
\text { Ley 18.700 Ley Orgánica Constitucional sobre Votaciones Populares y Escrutinios. } \\
\text { Ley 19.885 Incentiva y Norma el Buen Uso de Donaciones de Personas Jurídicas que } \\
\text { dan Origen a Beneficios Tributarios y los Extiende a Otros Fines Sociales y Públicos. }\end{array}$ \\
\hline Colombia & $\begin{array}{l}\text { Decreto 01 de 1984 (Código Contencioso Administrativo). Regula, entre otras } \\
\text { materias de procedimiento judicial, la acción pública de nulidad electoral. } \\
\text { Ley 996 del 24 de noviembre del 2005, que reglamenta la elección de Presidente de } \\
\text { la República de conformidad con el artículo 152 literal f) de la Constitución Política, y de acuerdo } \\
\text { con lo establecido en el Acto Legis lativo O2 de 2004. }\end{array}$ \\
\hline México & $\begin{array}{l}\text { En la Ley General del Sistema de Medios de Impugnación en Materia Electoral } \\
\text { (LGSMIME) del 22 de noviembre de 1996. }\end{array}$ \\
\hline
\end{tabular}

\section{Tabla 9. Leyes especiales partidos políticos}

Fuente: Elaboración propia, con base en información extraída de Zovatto D. (2011)

Es de destacar que en Colombia y México existen reglamentos sobre financiamiento de los partidos y en México éste se da por intermedio del Instituto Federal Electoral.

Igualmente, en el continente americano, existe gran libertad para la creación y constitución de partidos políticos e, incluso, de movimientos de ese carácter, encontrando las siguientes regulaciones al respecto:

\begin{tabular}{|c|c|}
\hline PAÍS & Regulación \\
\hline Chile & $\begin{array}{l}\text { La Constitución en su artículo } 19,15^{\circ} \text {, es tablece el derecho de } \\
\text { as ociarse sin permiso previo, por lo que se puede decir que exis te } \\
\text { una libertad amplia, en general, para la formación o constitución de } \\
\text { partidos políticos. }\end{array}$ \\
\hline Colombia & $\begin{array}{l}\text { Por dis posición constitucional todo ciudadano tiene el derecho de } \\
\text { constituir partidos, movimientos y agrupaciones políticas sin } \\
\text { limitación alguna, a formar parte de ellos libremente y difundir sus } \\
\text { ideas y programas. Artículos } 40 \text {, numeral } 3, \text { y } 107 \text { de la } \\
\text { Constitución. }\end{array}$ \\
\hline México & $\begin{array}{l}\text { No se puede coartar el derecho de as ociarse o reunirse } \\
\text { pacíficamente con cualquier objeto lícito; pero solamente los } \\
\text { ciudadanos de la República pueden hacerlo para tomar parte en los } \\
\text { asuntos políticos del país. Artículos } 9 \text {, párrafo primero, y } 35, \\
\text { fracción III, Constitución Política de los Estados Unidos } \\
\text { Mexicanos. }\end{array}$ \\
\hline
\end{tabular}

Tabla 10. Libertades en la constitución partidos políticos 
A manera de conclusión sobre las disposiciones legales, se establece que los países latinoamericanos, en su mayoría, tienen lineamientos requeridos para la formación e inscripción de partidos y que, el individuo, igualmente debe cumplir si quiere participar en el quehacer político.

Ahora bien, la forma que adoptan los partidos para organizarse y poder funcionar se llama estructura interna, gozando de una libertad amplia en este sentido y que actualmente se encuentran así:

\begin{tabular}{|c|c|c|}
\hline PAís & Normatividad & Intensidad \\
\hline Chile & $\begin{array}{l}\text { El artículo } 22 \text { de la Ley Orgánica de Partidos Políticos (LOPP.) } \\
\text { establece que cada partido se regirá por sus propios estatutos en su } \\
\text { estructura interna. } \\
\text { Entre los órganos de los partidos políticos deberán establecerse, al } \\
\text { menos, una Directiva Central, un Consejo General, Consejos } \\
\text { Regionales y un Tribunal Supremo. Artículo } 22^{\circ} \text { y } 23^{\circ} \text { de la Ley } \\
\text { Orgánica de Partidos Políticos (LOPP.). }\end{array}$ & $\begin{array}{l}\text { Poco } \\
\text { regulado }\end{array}$ \\
\hline Colombia & $\begin{array}{l}\text { El artículo } 107 \text { de la Constitución se limita a declarar que "Los } \\
\text { partidos y movimientos políticos se organizarán democráticamente". } \\
\text { El artículo } 6^{\circ} \text { de la ley } 130 \text { de } 1994 \text {, sobre Principios de organización } \\
\text { y funcionamiento, preceptúa: "Los partidos y movimientos políticos } \\
\text { podrán organizarse libremente", y señala la sujeción a la } \\
\text { Constitución y a principios fundamentales que enuncia. } \\
\text { El artículo } 7^{\circ} \text { de la Ley } 130 \text { se establece la obligatoriedad de los } \\
\text { estatutos, para regir tanto la organización, como el funcionamiento } \\
\text { de los partidos. }\end{array}$ & $\begin{array}{c}\text { Refiere a los } \\
\text { estatutos }\end{array}$ \\
\hline México & $\begin{array}{l}\text { Según el artículo } 27^{\circ} \text {, párrafo } 1 \text {, inciso c), del Código Federal de } \\
\text { Instituciones y Procedimientos Electorales (Cofipe), se establece } \\
\text { que entre los órganos con los que debe contar un partido político } \\
\text { nacional, y que deben estar previstos en sus estatutos, cuando } \\
\text { menos, se encuentran una as amblea nacional o equivalente; un } \\
\text { comité nacional o equivalente, que sea el representante nacional } \\
\text { del partido; comités o equivalentes en las entidades federativas, y } \\
\text { un órgano responsable de la administración de su patrimonio y } \\
\text { recursos financieros, y de la presentación de los informes de } \\
\text { ingresos y egresos anuales y de campaña. De tal forma, al tratarse } \\
\text { de un mínimo, los partidos políticos se encuentran en libertad de } \\
\text { elaborar la estructura que estimen pertinente. }\end{array}$ & $\begin{array}{c}\text { Muy } \\
\text { Regulado }\end{array}$ \\
\hline
\end{tabular}

Tabla 11. Estructura interna de los partidos según la Normatividad Fuente: Elaboración propia, con base en información extraída de Zovatto ( 2011)

De forma general, el funcionamiento y organización de los partidos políticos, es concordante a la práctica de las disposiciones legales que hacen parte del marco legal donde se estimulan las estructuras de los partidos y sus militantes. 
CRISIS DE REPRESENTACIÓN COMO CONSECUENCIA DEL TRANSFUGUISMO POLÍTICO EN

Finalmente, se señala las regulaciones existentes para la cancelación de los partidos políticos de acuerdo a cada país:

\begin{tabular}{|l|l|}
\hline \multicolumn{1}{|c|}{ País } & \multicolumn{1}{c|}{ Mínimo requerido } \\
\hline Chile & $\begin{array}{l}\text { 5\% de votos válidos, a menos que elija cuatro } \\
\text { parlamentarios en cada una de las dos últimas } \\
\text { elecciones pluripers onales. }\end{array}$ \\
\hline Colombia & $\begin{array}{l}\text { Por lo menos 50.000 votos, salvo que mantengan } \\
\text { representación en el Congreso }\end{array}$ \\
\hline México & \begin{tabular}{l} 
2\% de votos válidos \\
\hline
\end{tabular}
\end{tabular}

Tabla 12. Votación mínima para evitar cancelación de partidos Fuente: Elaboración propia, con base en información extraída de Zovatto $(2011)^{46}$

En estos tres países se evidencia diferencias sustanciales, entre ellas, la más marcada se establece en México, país que legisló en más de una elección; cuando los partidos políticos participaron en elecciones o cuando no participaron de forma sucesiva en más de una. Igualmente se denota los porcentajes altos que benefician a partidos grandes mientras que impiden la continuidad en los partidos pequeños, regulaciones que no contemplan Colombia y Chile. Se puede concluir que el trasfuguismo, no tiene como causa el sistema de partidos, ni la estructura de los partidos políticos; sino que es producto de la falta de identidad en las doctrinas, misión y visión contemplados en los estatutos y reglamentos, por su aplicación indebida, su aplicación no actualizada o simplemente por su total aplicación. 
CRISIS DE REPRESENTACIÓN COMO CONSECUENCIA DEL TRANSFUGUISMO POLÍTICO EN

COLOMBIA

3. Capítulo III: Aproximaciones normativas para combatir el transfuguismo político en Colombia y la relevancia de los movimientos sociales como nuevos mecanismos de representación.

En el capítulo anterior se profundizó sobre el transfuguismo político; tema central de ésta investigación y que cada día se hace más visible en nuestro País, motivo que permitió abordar el tema desde su mismo concepto para encontrar las razones que lo inducen a su implementación a consecuencia de los varios cambios políticos, estudio basado no sólo en las diferentes teorías de representación política y las formas de acción resultantes de la misma concepción de los partidos políticos, sus diversos sistemas y sus complejas formas evolutivas; sino además desde los actos legislativos que lo consagran.

Esto permite concluir cómo el transfuguismo político es inevitablemente funesto y totalmente negativo al sistema de partidos, porque sus autores provocan la creación de nuevos partidos y movimientos sin un sistema definido en cuanto a sus doctrinas, regulaciones y en torno a su estructura, y esto termina alimentando reacciones populares aciagas para la legitimidad democrática.

Estas medidas, al estar impulsadas más por la emoción que por la razón, son tremendamente perjudiciales a los partidos políticos porque los debilita al perderse identidad política como sentido de pertenencia en las razones que, permanentemente, deben existir para la consolidación de una representación que fortalezca la opción de conquistar el poder; poder que debe ejercerse en beneficio de toda la comunidad existente en el estado y, por ello, en este capítulo final, trataremos las diferentes alternativas que se conocen en aras de superar tan adverso propósito al sistema democrático existente. 


\subsection{Alternativas normativas}

\subsubsection{Análisis Jurídico del marco normativo vigente Frente al Trasfuguismo.}

Este análisis pretende abordar como ha sido la evolución normativa de la que ha sido objeto el fenómeno político del transfuguismo, teniendo en cuenta las consecuencias que le han sido establecidas a la inobservancia de su prohibición constitucional. Los actos legislativos que se tendrán en cuenta son el Acto Legislativo 01 de 2003 y el Acto Legislativo 01 de 2009.

Por lo anterior, se debe hacer énfasis en que el transfuguismo político es un concepto jurídicamente reciente que, aunque en la mayoría de países se ha intentado explicar, han sido pocos los autores que han brindado a la teoría el alcance y las variables que explican el fenómeno en las instituciones parlamentarias Cuéllar, (2012).

Recordemos, que en la representación política, el transfuguismo es considerado uno de los aspectos más problemáticos del actual sistema político, puesto que, desconoce el querer ciudadano que eligió al candidato perteneciente a un partido específico. De ésta forma no sólo transgrede la legitimidad del voto de los ciudadanos; sino que también suscita una deslegitimación al partido político al generar una fragmentación política al interior del parlamento, que como lo afirma García (1996) "es más a los partidos a quienes pertenece el escaño y no a los candidatos”. (p.70)

Lo anterior, hizo que se estableciera en el sistema electoral actual un factor especial como mecanismo en contra de la actuación tránsfuga de los militantes de las organizaciones partidistas, en ello se consagraron fórmulas indicadoras para que las fuerzas políticas obtengan 
CRISIS DE REPRESENTACIÓN COMO CONSECUENCIA DEL TRANSFUGUISMO POLÍTICO EN

o no representación ejerciendo una influencia vertical sobre el comportamiento y las estrategias de los electores y de los actores políticos.

En efecto, el Acto Legislativo 01 de 2003, producido por el Congreso de la República de Colombia, reforma el sistema político y electoral de la Nación, en busca de solucionar la crisis de representación en la que se encontraban sumergidos los partidos, buscando fortalecer el sistema de partidos, introduciendo importantes cambios y descollando los siguientes:

- Personería Jurídica y umbral:

Antes del 2003 para obtener la personería jurídica se necesitaba cumplir con las exigencias de la ley 130 de 1994 la cual requería bien, obtener 50.000 votos en la última elección al congreso, conseguir una curul en el congreso o bien, presentar como respaldo la misma cantidad de firmas de ciudadanos, requisitos que resultaron fáciles de superar, dando lugar a que emergieran empresas electorales con intereses económicos.

La reforma del 2003 buscó eliminar esto y por eso estableció en su artículo $2^{\circ}$.- que para obtener la personería jurídica se debe conseguir no menos del $2 \%$ de los votos válidos en las elecciones al congreso de la república, cuya evidencia favorable se observó en las elecciones al congreso del año 2006; esto, efectivamente, ocasionó el saneamiento de muchas organizaciones que no cumplían con los fines y elementos propios de un partido político y quedaron por fuera al no superar el umbral anteriormente señalado.

En las elecciones del 2010, se evidenció un mayor impacto de esta Reforma, al quedar el Senado integrado por ocho partidos políticos, de los cuales cuatro, alcanzaron a reunir 75 de los 102 senadores. En cuanto a la Cámara de Representantes solo 14 partidos lograron obtener representación. 
CRISIS DE REPRESENTACIÓN COMO CONSECUENCIA DEL TRANSFUGUISMO POLÍTICO EN

- Listas únicas y voto preferente:

En la Constitución política de 1991, no se colocaba límite al número de candidatos o listas por partido para las elecciones, lo que llevó al acto legislativo del 2003 a establecer en el artículo 12; (el cual modificó el artículo 263 de la Constitución Política), que las listas fueran cerradas; es decir, los mismos partidos dan el orden que deben llevar sus candidatos en las listas, pero no especificó que fueran listas bloqueadas, pues también determinó la eventualidad de que los votantes decidieran el orden de los candidatos para ocupar las curules, conforme a la lista presentada por el partido a través del voto preferente.

Igualmente, determinó que las listas presentadas por los partidos fueran únicas a razón de evitar la atomización en las mismas organizaciones políticas y por ende en la sociedad. Este requisito igualmente produjo resultados en las elecciones del año 2006, donde los partidos y movimientos políticos se enfrentaron por primera vez a los cambios efectuados al sistema electoral colombiano con el fin de fortalecer el sistema de partidos y, con ello, los partidos políticos. Como resultado sólo veinte (20) partidos presentaron listas únicas y se pasó de tener 76 partidos o movimientos políticos en el senado a tener 11 , de los cuales cinco forman parte de coaliciones favorables al gobierno y representan 61 de las 102 curules existentes.

En la Cámara de Representantes, se redujo a 22 partidos de los cuales 99 curules de 164 forman parte de la coalición gubernamental, presentando una significativa reducción con respecto a lo sucedido en las elecciones del año 2002. 
- Organización Democrática de los Partidos:

Igualmente, el artículo $1^{\circ}$ que modificó el artículo 107 de la Constitución Política, consagró la autonomía plena de los partidos políticos para establecer su organización interna. Esta autonomía en el funcionamiento interno de los partidos no garantizó la democracia dentro de las organizaciones partidistas y, por consiguiente, le correspondió al mismo partido fijar los mecanismos para determinar quiénes son sus candidatos, bien por aval de sus directivos o por consulta interna y/o popular, evento en el cual el Estado sería solo garante de dicha selección, apoyando igualmente con la logística necesaria para la práctica de la misma.

El acto Legislativo al que hacemos referencia incluyó además temas que dieron avance normativo al modificar elementos del sistema electoral, estableciendo mecanismos para regular la acción legislativa, como la financiación de los partidos y campañas políticas.

Sin embargo se considera que sólo lo atinente a la Personería Jurídica, al umbral, a las Listas únicas, al voto preferente y a la Organización Democrática de los Partidos, son referentes al tema que se trata porque, si bien no hablan directamente sobre el trasfuguismo político, si permiten referenciar que su aplicación trajo como consecuencia la reducción de partidos y movimientos políticos llevando a grandes deserciones de sus miembros.

Fue así como estos se vieron obligados a buscar otras toldas políticas, lo que fue previsto por el legislador y, por ello, en el mismo Acto legislativo 01 de 2003, se incluyó un parágrafo transitorio que otorgaba permiso para que los miembros de las corporaciones públicas cambien de partido sin incurrir en ninguna inhabilidad, ni en la perdida de la curul, es decir constitucionalizó; así fuera provisionalmente, el fenómeno del transfuguismo político, lo cual permitió que en un mismo periodo constitucional varios miembros de las corporaciones públicas incurrieran en actitudes tránsfugas causando alteraciones en el comportamiento 
CRISIS DE REPRESENTACIÓN COMO CONSECUENCIA DEL TRANSFUGUISMO POLÍTICO EN COLOMBIA

interno de los partidos, agravando sus propias crisis porque, al aprovecharse esta figura, quedó en evidencia la falta de disciplina y cohesión al interior de los partidos.

Sin embargo, es oportuno señalar que ese permiso constitucional, de cambiar de partido a los miembros que hacían parte de las corporaciones públicas, se consideró necesario para que quienes pretendían participar en próximas elecciones se mantuvieran en la arena política, superando las restricciones que se habían establecido en la reforma. Éstas de alguna manera estaban castigando a las organizaciones políticas pequeñas y por ende a sus miembros; aunque en definitiva no logró ser la solución a la problemática de falta de institucionalización, que se pretendió corregir.

El Acto Legislativo 01 de 2009, se enmarca en antecedentes que tienen que ver con el resultado de las elecciones del 2006, porque un número importante de parlamentarios elegidos, fue vinculado a investigaciones judiciales por presuntos nexos con grupos ilegales, especialmente, con los denominados paramilitares lo que dio origen al vocablo "parapolítica", fenómeno que deslegitimó aún más el sistema político y exigió transformaciones inmediatas, cuando un número cercano al 30\% de los congresistas electos, no pudieron seguir ocupando su curul al ser sancionados por estar incursos en ese suceso.

Este acto legislativo, buscó como objetivo fundamental la transparencia en las elecciones de los representantes de los ciudadanos, proscribiendo la existencia de vínculos con grupos al margen de la ley ya por financiación o por infiltración y, en general para evitar ejercicios de acciones ilegales en la política nacional, responsabilizando a los partidos por las actuaciones de sus candidatos y estableciendo como principales las siguientes medidas para los partidos políticos que de acuerdo con García E. , (2014) se señalan con personal orden, así: 
1) La organización democrática basada en los principios de transparencia, objetividad, moralidad, equidad de género, y el deber de presentar y divulgar sus programas políticos.

2) La autorización de las consultas interpartidistas, cuyos resultados deberán ser de obligatorio cumplimiento.

3)La responsabilidad de los partidos y movimientos políticos por toda violación o contravención a las normas que rigen su organización, funcionamiento o financiación, así como también por avalar candidatos elegidos en cargos o Corporaciones Públicas de elección popular, quienes hayan sido o fueren condenados durante el ejercicio del cargo al que se avaló, mediante sentencia ejecutoriada en Colombia o en el exterior por delitos relacionados con la vinculación a grupos armados ilegales y actividades del narcotráfico o de delitos contra los mecanismos de participación democrática o de lesa humanidad.

4) El incremento el porcentaje del umbral tanto para mantener la personería jurídica de partidos y movimientos políticos, como para participar en la asignación de escaños en el Congreso de la República.

Al respecto, dispuso en su Artículo 11: “(...)Para garantizar la equitativa representación de los Partidos y Movimientos Políticos y grupos significativos de ciudadanos, las curules de las Corporaciones Públicas se distribuirán mediante el sistema de cifra repartidora entre las listas de candidatos que superen un mínimo de votos que no podrá ser inferior al tres por ciento $(3 \%)$ de los sufragados para Senado de la República o al cincuenta por ciento (50\%) del cociente electoral en el caso de las demás Corporaciones, conforme lo establezcan la Constitución y la $\operatorname{ley}(\ldots) "$ 
5) La renuncia al menos con 12 meses de anterioridad, que debe hacer cualquier integrante de corporación pública que decida participar en las siguientes elecciones por un partido distinto al que se encuentra inscrito, consolidando definitivamente la prohibición de la doble militancia política,

6) La pérdida definitiva de la curul de los partidos políticos, que sólo se produce cuando se profiera sentencia condenatoria, debidamente ejecutoriada, por los delitos anteriormente relacionados con la vinculación a grupos armados ilegales y actividades del narcotráfico o de delitos contra los mecanismos de participación democrática o de lesa humanidad

7) La citación a nuevas elecciones en el evento de que la Corporación quede reducida a menos de la mitad de sus miembros.

8.) La nuevas funciones que sobre la materia, le atribuyó al Consejo Nacional Electoral; tema que por ser de gran importancia, por tratarse de la responsabilidad del estado, transcribimos:

“Artículo 12. El artículo 265 de la Constitución Política quedará así: El Consejo Nacional Electoral regulará, inspeccionará, vigilará y controlará toda la actividad electoral de los partidos y movimientos políticos, de los grupos significativos de ciudadanos, de sus representantes legales, directivos y candidatos, garantizando el cumplimiento de los principios y deberes que a ellos corresponden, y gozará de autonomía presupuestal y administrativa. Tendrá las siguientes atribuciones especiales:

1. Ejercer la suprema inspección, vigilancia y control de la organización electoral.

2. Dar posesión de su cargo al Registrador Nacional del Estado Civil. 
3. Conocer y decidir definitivamente los recursos que se interpongan contra las decisiones de sus delegados sobre escrutinios generales y en tales casos hacer la declaratoria de elección y expedir las credenciales correspondientes.

4. Además, de oficio, o por solicitud, revisar escrutinios y los documentos electorales concernientes a cualquiera de las etapas del proceso administrativo de elección con el objeto de que se garantice la verdad de los resultados.

5. Servir de cuerpo consultivo del Gobierno en materias de su competencia, presentar proyectos de acto legislativo y de ley, y recomendar proyectos de decreto.

6. Velar por el cumplimiento de las normas sobre Partidos y Movimientos Políticos y de las disposiciones sobre publicidad y encuestas de opinión política; por los derechos de la oposición y de las minorías, y por el desarrollo de los procesos electorales en condiciones de plenas garantías.

7. Distribuir los aportes que para el financiamiento de las campañas electorales y para asegurar el derecho de participación política de los ciudadanos, establezca la ley.

8. Efectuar el escrutinio general de toda votación nacional, hacer la declaratoria de elección y expedir las credenciales a que haya lugar.

9. Reconocer y revocar la Personería Jurídica de los partidos y movimientos políticos.

10. Reglamentar la participación de los Partidos y Movimientos Políticos en los medios de comunicación social del Estado.

11. Colaborar para la realización de consultas de los partidos y movimientos para la toma de decisiones y la escogencia de sus candidatos. 
CRISIS DE REPRESENTACIÓN COMO CONSECUENCIA DEL TRANSFUGUISMO POLÍTICO EN

12. Decidir la revocatoria de la inscripción de candidatos a Corporaciones Públicas o cargos de elección popular, cuando exista plena prueba de que aquellos están incursos en causal de inhabilidad prevista en la Constitución y la ley. En ningún caso podrá declarar la elección de dichos candidatos.

13. Darse su propio reglamento.

14. Las demás que le confiera la ley”.

A pesar de las novedosas medidas anteriormente señaladas como importantes para la consolidación de los partidos políticos en busca de su fortalecimiento institucional, (que supuestamente corregía la deserción de sus correspondientes miembros), la reforma estuvo fuertemente criticada debido a que estimuló el transfuguismo político, aunque fuera de forma temporal, repitiendo con otros argumentos, pero al fin y al cabo repitiendo lo permitido en el acto legislativo del año 2003, al disponer que en los dos meses siguientes a su entrada en vigencia, los militantes miembros de corporaciones públicas elegidos por voto popular, podían cambiarse a una organización política diferente a aquella por la que se habían inscrito para obtener la curul que ocupaban, sin renunciar a ésta o incurrir en doble militancia política.

En síntesis los actos legislativos analizados, constitucionalizaron la figura del trasfuguismo político al consagrar parágrafos transitorios en los que se permitía cambio de partido de los elegidos y que transcribimos como testimonio de tan incoherente propósito, cuando se trataba era de eliminar tan reprochable conducta.

El Acto legislativo 01 de 2003, modificó el Artículo 108 de La Constitución Política de Colombia expedida por el constituyente en el año de 1991 y le incluyó el siguiente; 
CRISIS DE REPRESENTACIÓN COMO CONSECUENCIA DEL TRANSFUGUISMO POLÍTICO EN COLOMBIA

“[...]PARÁGRAFO TRANSITORIO 1o. [...] Para efectos de participar en cualquiera de las elecciones que se realicen desde la entrada en vigencia de esta Reforma hasta las siguientes elecciones de Congreso, los partidos y movimientos políticos con representación en el Congreso podrán agruparse siempre que cumplan con los requisitos de votación exigidos en la presente Reforma para la obtención de las personerías jurídicas de los partidos y movimientos políticos y obtengan personería jurídica que reemplazará a la de quienes se agrupen. La nueva agrupación así constituida gozará de los beneficios y cumplirá las obligaciones, consagradas en la Constitución para los partidos y movimientos políticos en materia electoral $[\ldots] "$

El Acto legislativo 01 de 2009, modificó el Artículo 107 de La Constitución Política de Colombia expedida por el constituyente en el año de 1991 y le incluyó el siguiente;

“[...] PARÁGRAFO TRANSITORIO 1o. Sin perjuicio de lo dispuesto por el artículo 134, dentro de los dos (2) meses siguientes a la entrada en vigencia del presente acto legislativo, autorizase, por una sola vez a los miembros de los cuerpos colegiados de elección popular, o a quienes hubieren renunciado a su curul con anterioridad a la vigencia del presente acto legislativo, para inscribirse en un partido distinto al que los avaló, sin renunciar a la curul o incurrir en doble militancia $[\ldots]$ 
CRISIS DE REPRESENTACIÓN COMO CONSECUENCIA DEL TRANSFUGUISMO POLÍTICO EN COLOMBIA

Estos parágrafos transitorios, suscritos en las mencionadas reformas; que si bien buscan la disciplina y consolidación de partidos políticos fuertes, en la práctica han permitido el transfuguismo político a gran escala, entre otras razones porque los actores parlamentarios son los mismos que determinan y ejecutan a su propia conveniencia tanto la Constitución como las mismas leyes y, por ende, las señaladas prohibiciones podrán seguir siendo modificadas para preservar la ya constitucionalizada conducta bajo el argumento de que, permitida una vez, permitida siempre, en el entendido de que existirán en su momento razones más que suficientes que la justifique.

Es necesario en consecuencia, propender por crear un mecanismo de autorregulación que refleje transparencia ante la ciudadanía para lograr minimizar la brecha existente; que ha sido la generadora de la deslegitimación sobre las instituciones, mecanismo que permita, además, rescatar la credibilidad ciudadana porque si, definitivamente la falta de responsabilidad de los miembros del legislativo sigue campeando bajo las banderas de su propio interés, desconociendo el de sus representados y por tanto no cumpliendo con la soberana responsabilidad de consolidar el sistema de partidos y a éstos mismos; debe buscarse la forma de relevarlos de ella y dejar que sea el pueblo el que proceda a hacerlo mediante el mecanismo más conveniente, escogido de entre los consagrados en la Constitución e incluso de nuevos si fuere necesario.

\subsubsection{Modificaciones a la Ley de Bancadas}

En el año 2003 se radicó el proyecto de Ley 066 de Senado y 075 de Cámara, con el cual se buscaba reglamentar el funcionamiento de los partidos políticos, proyecto convertido en la ley 974 del año 2005 y conocida con el nombre de Ley de Bancadas, que consagró 
CRISIS DE REPRESENTACIÓN COMO CONSECUENCIA DEL TRANSFUGUISMO POLÍTICO EN COLOMBIA

objetivos claros para darle la aplicación de manera efectiva a las medidas efectuadas por la reforma del Acto Legislativo del año 2003. Es decir, la Ley creó herramienta para darle vigencia práctica a las reglas de juego de los partidos estableciendo, como su función principal, el establecimiento de un régimen disciplinario a las organizaciones existentes hasta ese momento en el país, de tal forma que prescribió las posibles sanciones aplicables a los trásfugas por parte de las colectividades políticas, a quienes se les confirió el derecho de sancionar a sus miembros, bien despojándolos de su voto o bien expulsándolos de la colectividad por desleales.

Como lo manifiestan Botero y Rodríguez; citados por García, (2014), con esta ley se pretendió superar la crisis en los partidos políticos por medio del establecimiento de las bancadas, para obtener niveles de corresponsabilidad entre la actuación individual de cada congresista, con su respectiva colectividad política y con la ciudadanía, como se indicó en el artículo 2 de la mencionada ley, que dispuso:

“Artículo $2^{\circ}$. Actuación en Bancadas. Los miembros de cada bancada actuarán en grupo y coordinadamente y emplearán mecanismos democráticos para tomar sus decisiones al interior de las corporaciones públicas en todos los temas que los Estatutos del respectivo Partido o Movimiento Político no establezcan como conciencia"

La Contraloría General de la República, en el año 2010, al referirse a la citada ley de Bancada; que como se expuso anteriormente, reglamentó los cambios constitucionales contenidos en la reforma política del año 2003; compartió lo anteriormente expuesto, de cómo a través del establecimiento de bancadas o grupos congresuales, se fortalecía 
CRISIS DE REPRESENTACIÓN COMO CONSECUENCIA DEL TRANSFUGUISMO POLÍTICO EN COLOMBIA

"el funcionamiento del legislativo y de los partidos políticos; dando mayor desarrollo al control político que debe ejercer el Congreso, no solo para una mejor función legislativa, sino para bien de los partidos o movimientos políticos, tanto al interior como por fuera del Congreso, al generar mayores niveles de corresponsabilidad entre la actuación individual de cada congresista, su respectiva colectividad política y la ciudadanía”. (Contraloría General de la República, 2010).

Luego de que la ley entrara en vigencia, los partidos políticos se dieron a la tarea de incluir dentro de sus estatutos y reglamentos internos de funcionamiento, artículos que promovieran el cumplimiento de la ley de bancadas a cabalidad; sin embargo como lo firma la Entidad mencionada, “(....) La aplicación de la ley de bancadas no ha surtido el efecto esperado, aunque sirvió para que los partidos se consolidaran (...)" (Contraloría General de la República, 2010).

Analizando esta norma, se encuentran elementos y vacíos que no se tuvieron en cuenta, destacando los siguientes:

- El desarrollo de una cultura política y una conciencia de partido. Pese a ser un principio consagrado no sólo en la ley, sino en los estatutos internos de los partidos, los miembros de las colectividades políticas no lo cumplen.

- La aplicación de controles en el desarrollo de la ley: Si bien es cierto que cada partido y movimiento político es autónomo, la normatividad no hace explícito establecer un tipo de control o una tipología de sanciones al interior de cada colectividad o, incluso, en el mismo Congreso para garantizar un mayor cumplimiento tanto del reglamento interno de los partidos como de la "ley de bancadas". En esa medida, cabe establecer un sistema de control que permita velar por el cumplimiento adecuado de esta ley. 
CRISIS DE REPRESENTACIÓN COMO CONSECUENCIA DEL TRANSFUGUISMO POLÍTICO EN COLOMBIA

- Transfuguismo. El transfuguismo ha sido uno de los elementos que mayores obstáculos ha suscitado para el desarrollo de las bancadas en el Congreso y si bien en esta ley, reglamentaba en el artículo transitorio 20 de la ley de bancadas (974/05) lo implementado en la Reforma Política 2003, como período de gracia, permitió el transfuguismo en el Legislativo al autorizar que por una sola vez los representantes a la Cámara elegidos para el periodo 2002-2006 pudieran afiliarse a movimientos o partidos diferentes a los que avalaron sus candidaturas, amparado en la creación de nuevas agrupaciones de congresistas y de nuevos partidos políticos, con miras a las elecciones de 2006; la Corte Constitucional, mediante sentencia C-453 del año 2006 lo declaró inexequible, por cuanto consideró que dicho artículo desconoció los principios de consecutividad y de identidad flexible o relativa, al no debatirse con las formalidades establecidas en el reglamento del congreso en la Plenaria de la Cámara de Representantes y por ende lo consagrado en el referido Acto Legislativo quedó sin reglamentación. (http://www.corteconstitucional.gov.co/relatoria/)

No obstante; como anteriormente ya se expuso, el legislativo en su carácter de constituyente, con la promulgación de la Reforma Política de 2009 (Acto Legislativo 001 de 2009), abrió otro período de gracia para permitir que varios senadores y representantes cambiaran de partido político para las elecciones del año 2010.

De este modo, las implicaciones políticas de cambiar la normatividad en cada período electoral y las implicaciones del transfuguismo en la alineación de alianzas cohesionadas, son escenarios que deben entrar al debate: no sólo del análisis sobre la aplicación de la ley de bancadas, sino especialmente el inciso final del artículo $4^{\circ}$, con respecto a su vigencia, porque, definitivamente permite el transfuguismo, cuando consagra:

“(...)No incurrirá en doble militancia, ni podrá ser sancionado el miembro de corporación pública o titular de un cargo de elección popular que se inscriba como 
CRISIS DE REPRESENTACIÓN COMO CONSECUENCIA DEL TRANSFUGUISMO POLÍTICO EN

candidato para un nuevo período por un partido, movimiento o grupo significativo de ciudadanos diferente del que lo avaló en la elección anterior, siempre y cuando medie notificación oportuna y cumpla con los deberes de la bancada de la cual hace parte"(...) (Inciso final artículo 4º Ley de Bancadas 2005)

Es importante, entonces medir el impacto que han tenido las reformas políticas en la configuración del sistema de partidos políticos con que cuenta actualmente nuestra República de Colombia, porque el hecho notorio es que, la población en elecciones, está mirando más a las personas que aspiran que al partido político por el que se inscriben, con la gravedad de no darle su representación, sino de venderle su propia consciencia política.

Por tanto las buenas intenciones del legislador constitucional al proferir los Actos Legislativo del año 2003, (con su reglamentación con la ley en comento que para sus efectos reformó la ley $5^{\text {a }}$ de 1992 ( reglamento interno del Congreso) y del año 2009, cuya importancia era la de configurar un sistema de partidos sólido, teniendo en cuenta el voto nominal y público en la disciplina legislativa de las bancadas y en el desarrollo del proceso legislativo en el Congreso de la República), en sus efectos finales; hoy, solo se quedan en buenas intenciones, porque no existe quien las haga cumplir, en la medida en que al interior de los partidos y movimientos políticos, las personas encargadas de hacerlo no asumen dicha responsabilidad limitándose solo a sancionar a los partidarios como consecuencia de haber sido condenados bien penal o fiscalmente; es decir, no atienden la independencia y autonomía de la actividad disciplinaria.

Aunado a lo anterior, el legislador incurre en graves confusiones en su propio reglamento (Ley 5a/92 y sus reformas, entre ellas la ley 974/2005) porque no existe claridad con respecto a la actuación individual de sus miembros y la obligación que éstos tienen de 
CRISIS DE REPRESENTACIÓN COMO CONSECUENCIA DEL TRANSFUGUISMO POLÍTICO EN COLOMBIA

actuar como parte de la bancada política en la que se inscribieron para las elecciones legislativas.

En efecto, La ley de bancadas hace énfasis en la actuación en grupo político, el que como tal, tiene la facultad de promover citaciones o debates y de intervenir en ellos; a participar con voz en las plenarias, a intervenir en la discusión de proyectos normativos y a votar en las mismas, presentar mociones, interpelaciones, solicitar votaciones nominales y postular candidatos, pero a su vez consagra: "Lo anterior sin perjuicio, de las facultades o atribuciones que por virtud del Reglamento del Congreso se les confiere de manera individual a los congresistas"; ¿significa entonces, que los congresistas tiene los mismos derechos, bien si actúan como pertenecientes a una bancada o bien si actúan de manera individual?, interrogante que en principio defendió el legislador, cuando dispuso en el Artículo $5^{\circ}$ de la ley 974/05, lo siguiente:

“...ARTÍCULO 5o. DECISIONES. Las bancadas adoptarán decisiones de acuerdo con lo dispuesto en el artículo segundo de esta ley. Cuando la decisión frente a un tema sea la de dejar en libertad a sus miembros para votar de acuerdo con su criterio individual, se dejará constancia de ello en el acta respectiva de la reunión de la bancada. (Bastardilla y resaltado fuera de texto).

La bancada puede adoptar esta decisión cuando se trate de asuntos de conciencia, $\boldsymbol{o}$ de aquellos en los que, por razones de conveniencia política, de trámite legislativo o controversia regional en el caso de la Cámara de Representantes, los miembros de las bancadas decidan no adoptar una decisión única. (Bastardilla y resaltado fuera del texto.) 
CRISIS DE REPRESENTACIÓN COMO CONSECUENCIA DEL TRANSFUGUISMO POLÍTICO EN

Cuando exista empate entre sus miembros se entenderá que estos quedan en libertad de votar."

La Corte Constitucional, atendiendo demanda de inconstitucionalidad con el argumento que lo resaltado en la norma citada, vulneraba lo dispuesto en el artículo 108 de la Constitución Política, mediante la sentencia C- 974 del 2006, efectivamente manifiesta que existe contradicción entre lo demandado y lo consagrado en la Constitución y por tanto procede a declarar la INEXIQUIBIDILAD, de los apartes de la norma demandada, indicando, que; “(...) la ley demandada según la cual los congresistas pueden votar según su criterio individual cuando así lo consideren las correspondientes bancadas en virtud de razones de "conveniencia política, de trámite legislativo o de controversia regional", como excepciones a la actuación en bancada, resultan violatorias del mandato constitucional.

En efecto, de una parte corresponde a cada partido o movimiento definir los asuntos de conciencia que no se sujeten al régimen de bancadas.

De otro lado, la generalidad y ambigüedad de la cláusula demandada convierte prácticamente en regla general la excepción de actuación individual de los miembros de las corporaciones públicas. En efecto, las "razones de conveniencia política, trámite legislativo o controversia regional", cubren casi todo el espectro de las decisiones que deben ser adoptadas al seno de las corporaciones públicas $\mathrm{y}$, por ello, permiten un amplio margen de discrecionalidad de los partidos y movimientos políticos que hacen nugatorios los propósitos de la reforma política contrariando abiertamente el artículo 108 superior. Por consiguiente, las expresiones demandadas del artículo $5^{\circ}$ de la Ley 974 de 2005 deben ser declaradas inexequibles. 
CRISIS DE REPRESENTACIÓN COMO CONSECUENCIA DEL TRANSFUGUISMO POLÍTICO EN

Queda claro entonces que los partidos solo podrán dejar en libertad para votar a sus miembros cuando sea en asuntos de Libertad de conciencia o asuntos de conciencia y que deben ser determinados por cada partido o movimiento político, bajo los parámetros del artículo 18 de la Constitución Política que consagra:

“...Se garantiza la libertad de conciencia. Nadie será molestado por razón de sus convicciones o creencias ni compelido a revelarlas ni obligado a actuar contra su conciencia..."

Norma que se conoce como la objeción de conciencia, concepto que en sentido amplio, se entiende como: “(...)el rechazo al cumplimiento de determinadas normas jurídicas por ser éstas contrarias a las creencias éticas o religiosas de una persona(...)" (Mateus \& Velasco, 2010, p. 145).

Sin embargo, a pesar de tan claros conceptos, la Corte Constitucional, en la sentencia anteriormente citada, refiriéndose a los asuntos de conciencia, dijo:

“... En este sentido cabe indicar que cuando la Carta se refiere a "asuntos de conciencia" no se está limitando exclusivamente a las cuestiones que pueden dar lugar a la objeción de conciencia de que trata el artículo 18 de la Carta. Compete a cada partido o movimiento, en virtud de su autonomía, definir los asuntos de conciencia que queden eximidos del régimen de bancadas. En este sentido, la reforma se sitúa en un punto intermedio entre el régimen liberal clásico de representación individual y el sistema fuerte de partidos que no da espacio a la 
CRISIS DE REPRESENTACIÓN COMO CONSECUENCIA DEL TRANSFUGUISMO POLÍTICO EN

acción individual de la persona que ha sido popularmente elegida para pertenecer a una de las corporaciones públicas...” (Corte Constitucional, 2006)

El problema de esta decisión de la Corte radica en que se corre el peligro de que la objeción de conciencia; mientras no sea reglamentada en el interior de cada colectividad política, se convierta en la excusa perfecta de los miembros desobedientes de las bancadas políticas para escapar a la obligación que les corresponde, riesgo que conlleva hasta la posibilidad de retiro de la colectividad del inconforme y, en ese sentido, la normatividad estudiada.

Igualmente lo anterior da cabida al trasfuguismo sin que este hecho les acarree sanción alguna, cuando en el reglamento del partido que ingresa, se acoge el hecho que motivó el retiro del trásfuga, porque si cada partido es el responsable de la reglamentación de la objeción de conciencia, existirán razones conforme a la existencia de los partidos o movimientos políticos, en que algunas coincidirán y otras serán hasta contradictorias.

Ejemplo de ello, sería la citación a reuniones, cuando el día de descanso para unos es el día sábado y para otros el día domingo, oportunidad que puede aprovecharse para retirarse del partido, si se insiste en que es un día determinado que no le conviene al elegido por convicción religiosa; hipótesis de gran viabilidad que en nada ayuda al propósito de que cada vez más los partidos y movimientos políticos generen, promuevan y realicen un seguimiento juicioso de los postulados programáticos que quieren desarrollar y defender en forma grupal y que distancien acuerdos con las coyunturas electorales y políticas a las que se ven enfrentados; y, por el contrario, siguen lastimosamente permitiendo el trasfuguismo político. 


\subsection{Movimientos Sociales como mecanismos de representación}

Cuando los partidos y sistema de partidos cambian su enfoque ideológico, la consecuencia es el distanciamiento entre éstos y la sociedad civil; pero, además, conlleva el reconocimiento de lazos débiles de normatividad en el proceso de competencia entre partidos y de cómo se relacionan con los actores sociales, hechos que permiten que emerjan diversos movimientos sociales.

En los últimos períodos, Latinoamérica se ha enfrentado a la llamada crisis de representación y de gobernabilidad experimentada en protestas sociales contra el modelo o enfoque político que tienen los diferentes estados. Cada vez existen más fenómenos de expansión globales como la corrupción, el narcotráfico y el terrorismo..., producto de la imposibilidad de los sistemas políticos tradicionales, como partidos políticos, congresos y gobiernos, para operar situaciones de disolución.

Esta falencia los obliga a realizar alianzas con otras organizaciones, no sólo nacionales, sino internacionales y, en algunas oportunidades, otorgan relativas soluciones y, en otras resultan ineficientes, oportunidad que no pierden los movimientos que conservan un desafío constante con las fuerzas políticas tradicionales en detrimento de la institucionalidad democrática, (que para los mismos movimientos no funciona), generando desconfianza y descrédito hacia los partidos políticos.

Se podría entonces argüir que dicha posición es estéril para canalizar las demandas de los diferentes sectores del conglomerado quienes optan por constituir movimientos sociales en los que logran expresar sus variadas necesidades. Algunos de esos movimientos sociales se han convertido en movimientos políticos que logran llegar al poder con el que institucionalizan sus ideales directamente en el ejercicio político. 
CRISIS DE REPRESENTACIÓN COMO CONSECUENCIA DEL TRANSFUGUISMO POLÍTICO EN COLOMBIA

Los movimientos sociales emergen en América Latina con mayor fuerza representativa a partir de los años noventa, como consecuencia del descontento social que generaba la pérdida de legitimidad de los partidos políticos. Entre ellos se recuerda el movimiento zapatista de México, que tomo como causa, la defensa de las demandas indígenas y de los campesinos en el momento en que, el Estado Federal, comenzaba a firmar acuerdos de libre comercio con los Estados Unidos. (USA).

Con respecto a las explicaciones sobre los movimientos sociales Inglehart (1990) señala:

“(...) los movimientos sociales a los que le adjudican el adjetivo de 'nuevos', representan el cambio cultural producido en las sociedades industriales avanzadas, caracterizado entre otros aspectos, por el paso de valores materialistas a valores de carácter 'postmaterialista'; es decir, el cambio de la preocupación por la seguridad física o los recursos de primera necesidad al énfasis en la autoexpresión, el sentimiento de pertenencia a la comunidad y la calidad de vida (...)"(p. 97)

La mayoría de los movimientos sociales surgen especialmente de clases media baja, estas se movilizan por la falta de empleo, bajos salarios, poca prestación de servicios públicos y total o escaso acceso a vivienda digna.

Algunos movimientos de Latinoamérica nacieron como respuesta al detrimento de su baja calidad de vida en los últimos treinta años. La evolución en las estructuras de poder, en varios países, permitieron que los movimientos alcanzaran gran ímpetu y ampliaran su poder de convocatoria y movilización. Del mismo modo, la desconfianza y la pérdida de legitimidad de algunas de las instituciones democráticas, como los partidos políticos, ayudó a la 
CRISIS DE REPRESENTACIÓN COMO CONSECUENCIA DEL TRANSFUGUISMO POLÍTICO EN

agrupación de la sociedad civil conforme a sus necesidades comunes, consolidando la formación de dichos movimientos sociales en la medida en que engrosaban sus huestes.

Como lo manifestó Rucht (1996) un movimiento social está compuesto por dos características principales:

“(...)1) Redes de grupos y organizaciones preparados para la movilización y actos de protesta para promover o (resistir) el cambio social (que es el objetivo último de los movimientos sociales).

2) Individuos que asisten a actos de protesta o contribuyen con recursos sin ser necesariamente parte de un grupo u organización del movimiento (...)”. (p. 187).

Las organizaciones emanadas de los movimientos sociales y que forman sus estructuras, hacen que se parezcan a algunos partidos políticos y en esto se hace imperioso determinar cuáles son las diferencias que existen entre ellos por cuanto, el fin real del movimiento social es, en últimas, acceder a la política de una u otra forma.

El convertirse en partido fortalece el grupo y su interés en los objetivos programáticos que centran en la representación, esto les permite dejar de depender de la participación de sus miembros para la obtención de los fines buscados; igualmente, adquieren recursos más amplios y tienen un grado de institucionalización, profesionalización y autoridad que les hace suprimir las movilizaciones públicas.

Por otro lado, de acuerdo a lo manifestado por PNUD - OEA (2010), existen otras formas de participación como las organizaciones de la sociedad civil u organizaciones no gubernamentales. Entre ellas existen las organizaciones estructuradas que provienen de 
CRISIS DE REPRESENTACIÓN COMO CONSECUENCIA DEL TRANSFUGUISMO POLÍTICO EN COLOMBIA

identidades concretas como son el género, el multiculturalismo o motivos sociales como la conservación del ambiente o la protección del consumidor. (p. 128).

La intervención de la sociedad civil, presenta grandes diferencias con respecto a los partidos políticos, por cuanto éstos, para elecciones, buscan el apoyo de la sociedad civil, apelando a coaliciones diversas que casi siempre terminan con problemas, precisamente, por no fijar y sustentar con claridad su posición frente a las diferentes dificultades que envuelven a la sociedad civil.

Otra diferencia es el estatus que tiene un representante de un partido al ser elegido, con respecto a los líderes de la sociedad civil que carecen de esa legitimidad ante la democracia.

Todas estas situaciones de baja calidad institucional, (escaso arraigo social del sistema de partidos políticos, movilizaciones de la sociedad civil), permiten que los líderes de movimientos sociales reciban el apoyo popular de manera rápida y relativamente fácil valiéndose de manifestaciones callejeras para lograr la masificación de sus propósitos, de ahí; como lo dice el informe del PNUD - OEA, (2010), que la supervivencia de la democracia está dada a que la sociedad civil se conecte con los partidos políticos y con las instituciones.

En América Latina, los movimientos con más auge han sido:

- El movimiento campesino.

- El movimiento obrero.

- Movimientos de clase media.

- Movimiento estudiantil. 
- Movimiento étnico.

- Movimientos femeninos.

El estudio de los movimientos sociales permite entender el poder de una manera diferente, en la medida en que, éste, no reside solamente en el Estado; sino que también está presente en las relaciones sociales y, por tanto, es posible reconocer que la construcción de la democracia no es una tarea política que le corresponde única y exclusivamente al Estado o a los partidos; sino que, también, es una tarea social que supone cambios en las relaciones de poder existentes en el seno de la sociedad civil (Restrepo, 1990). En otras palabras, la democracia no es solamente un proyecto de Estado; sino también un proyecto de nueva sociedad no discriminatoria, no racista, no machista.

Obviamente, la mayor presencia de los movimientos sociales significa una mayor democracia, en el sentido de la superación de la democracia formal, (limitada al problema de la representación, el derecho al voto, la alternancia en el poder, etc.), y de la democracia preocupada por generar igualdad de oportunidades para superar los desequilibrios internos.

Sin embargo, no se debe confundir esta enorme potencialidad de los movimientos sociales con la realización efectiva e inmediata de la democracia participativa, puesto que hoy se asiste a una compleja constitución de la subjetividad social de los actores sociales.

Puede ser que estén surgiendo, en este momento, nuevas formas de subjetividad y de acción social, expresadas en los nuevos movimientos sociales que aún no se comprenden fácilmente. Puede ser que, en el futuro, se constituya una subjetividad no clasista que, no obstante, reivindique el cambio social.

Eso nadie lo puede predecir con certeza; pero, por el momento, hay una multiplicidad de subjetividades que no se articulan fácilmente y que, por lo tanto, tienen enormes 
CRISIS DE REPRESENTACIÓN COMO CONSECUENCIA DEL TRANSFUGUISMO POLÍTICO EN COLOMBIA

dificultades para hacer valer la democracia-participativa frente a los centros consolidados de poder.

Por eso se estudiará, por separado, cómo ha sido la evolución de los movimientos políticos en Chile y México y en perspectiva comparada con Colombia.

\subsubsection{Movimientos Sociales Chile}

Chile vive hoy una crisis alta de legitimidad, producto de un sistema político endurecido que limitó los incentivos y las herramientas para solventar la situación y que, logró además, una casi nula interacción con la sociedad civil del país en las últimas tres décadas.

Dicha crisis, resulta de un proceso de politización, que elevó la desigualdad en sus varias manifestaciones a nivel social ante la imposibilidad del sistema político para procesar institucionalmente la demanda social con mayor igualdad y menos abuso. (Henriquez, 2010).

Además, una sociedad que se ha vuelto relativamente más horizontal, se confronta a un sistema de partidos que se desempeña y se representa en clave oligárquica. Es así que, la presunción respecto a la alianza entre el poder económico y el poder político, frecuentemente denunciada por distintos actores sociales; deriva ser un catalizador de la insatisfacción respecto a la élite.

Los cambios ocurridos en los últimos veinte años en la sociedad son resultado de un modelo de progreso concebido en altos niveles de desarrollo económico, acceso a bienes de consumo e demandas más frecuentes de movilidad social ascendente. Si bien, el crecimiento económico contribuyó a legitimar al sistema político y su funcionamiento, esa fuente de 
CRISIS DE REPRESENTACIÓN COMO CONSECUENCIA DEL TRANSFUGUISMO POLÍTICO EN COLOMBIA

legitimidad ya no es suficiente. Además, se aumenta el descontento social con las promesas incumplidas del modelo, dominando un lugar esencial la falsa promesa de movilidad intergeneracional a través de la inversión y el logro educativo y la progresiva percepción de abuso por parte de las grandes corporaciones y del sistema financiero. (Fundación Konrad Adenauer-KAS-Colombia, 2014).

La crisis chilena se produce, paradójicamente, en un contexto relativo, alto y sostenido en el crecimiento económico. Chile tiene un sistema político robusto y anclado al nivel institucional que produce un resultado contradictorio; un sistema cada vez más ilegítimo en términos sociales. Origina así, el desánimo en procesos de adaptación partidaria y renovación programática capaces de contribuir a encauzar y canalizar la demanda social y, al mismo tiempo, desgasta los movimientos sociales.

De esta forma, la crisis de legitimidad no tiene desenlace en el corto plazo, generando nuevos incentivos para que la clase política tienda a aferrarse cada vez con más vehemencia a los mecanismos institucionales de anclaje; si bien estos son bien conocidos, aquí también operan mecanismos no institucionales.

En el 2011, el consentimiento del modelo chileno se fracturó, las movilizaciones estudiantiles y sus variadas protestas marcaron un punto de inflexión. Chile presenta un síndrome que ha sido común en Latinoamérica, un profundo alejamiento entre la sociedad y los partidos, y una creciente devaluación de los procesos electorales y de las instituciones representativas. (Fundación Konrad Adenauer-KAS-Colombia, 2014).

En los últimos años, múltiples conflictos sociales han logrado visibilidad pública en las calles como el conflicto mapuche, varias protestas ambientales, de los deudores habitacionales y las protestas por la reestructuración del sistema de transporte capitalino mediante el Plan Transantiago. Estos movimientos sociales fueron enfrentados con varios 
CRISIS DE REPRESENTACIÓN COMO CONSECUENCIA DEL TRANSFUGUISMO POLÍTICO EN COLOMBIA

instrumentos que, mezclados en diversos paquetes, que fueron exitosos en cuanto a la terminación de las protestas; esos instrumentos fueron:

a) mecanismos de negociación y cooptación usualmente articulados en torno a mesas de diálogo;

b) concesiones puntuales que respondían a la demanda ciudadana, usualmente articuladas vía procesos de política pública fuertemente tecnocráticos, los que también buscaban generar quiebres internos en el movimiento; e

c) instancias de represión selectiva y focalizada hacia los grupos más radicales. (Luna, 2014).

Con la irrupción del movimiento estudiantil llamado “pingüino”, en el año 2006, los jóvenes chilenos saltaron a la escena política nacional desvirtuando el supuesto respecto a su apatía, ("no están ni ahî", Luna, 2014). ${ }^{18}$ Por lo tanto la movilización social terminó con la reforma a la Ley Orgánica Constitucional de Educación por la Ley General de Educación aprobada durante el régimen militar.

Así, de acuerdo a lo planteado por Luna (2014), el reto de los partidos políticos en Chile va por partida doble: necesitan fortalecerse institucionalmente como actores colectivos dado que tienen la habilidad de convocatoria social. (p.49)

\subsubsection{Movimientos Sociales México}

En la historia de México de los últimos 30 años ha habido una transformación radical del modelo de desarrollo de industrialización que ha sido sustituido por importaciones en un

\footnotetext{
${ }^{18}$ Luna. J, 2014, ¿Crisis de legitimidad en Chile? Movilizaciones sociales y sistema político.
} 
CRISIS DE REPRESENTACIÓN COMO CONSECUENCIA DEL TRANSFUGUISMO POLÍTICO EN COLOMBIA

proceso de transnacionalización del mercado interno y, junto a ello, se ha reconfigurado el régimen político sometiendo a los mexicanos a fuertes tensiones. La clase media, los indígenas, los intelectuales, los artistas, los campesinos, los jóvenes, los sindicatos; además de otros actores sociales, como los obreros y las mujeres; viven estos procesos sin que, hasta ahora, sea evidente que se desarrollan para su beneficio. (Bizberg \& Zapata, 2010).

Las organizaciones tradicionales que respaldaban el régimen autoritario mexicano se fueron debilitando desde el cambio en el modelo de desarrollo, así, el sindicalismo que se originó desde el viejo régimen, ha sufrido los efectos de la elasticidad aplicada por las empresas, por el surgimiento de sectores manufactureros con una menor sindicalización (la maquila), y por la tercerización de la economía.

Sin embargo, como lo argumentan Bizberg \& Zapata (2010), la deslegitimación que significó apoyar las medidas liberales durante los sexenios de los presidentes De la Madrid, Salinas y Zedillo; también jugaron un papel primordial en el debilitamiento de los sindicatos. (p.37).

El Congreso del Trabajo aceptó el nuevo proyecto económico liberal a cambio de mantener a las dirigencias y algunas de las prestaciones de los sindicatos más estratégicos. La subordinación sindical a los gobiernos del PRI, permitió que se debilitara el control del sindicalismo sobre el mercado de trabajo y su capacidad de decisión al interior de las empresas sin afectar su monopolio organizativo.

Esta situación de debilidad se ha acentuado por el hecho de que, los sindicatos, no fueron capaces de compensar la influencia perdida en los sectores extractivo, industrial y público, para trasladarla a los sectores que más se desarrollaron en estos 20 años: el sector informal, el sector maquilador y el del comercio y servicios, según lo indica Dagnino (2002). 
CRISIS DE REPRESENTACIÓN COMO CONSECUENCIA DEL TRANSFUGUISMO POLÍTICO EN

En México se dieron eventos especiales dentro del contexto latinoamericano en el transcurrir histórico de la creación de los movimientos sociales, por lo que se realizará un rastreo general desde los años sesenta, a partir de lo expuesto por María Fernanda Somuano, en el capítulo 7 del libro de Bizberg y Zapata (2010, pp. 252-259).

Los sesenta y setenta fueron en México años de expansión de las clases medias. Nuevos actores sociales aparecieron en la arena política y se enfrentaron al Estado mexicano con el fin de lograr mayor apertura en el sistema político. Uno de esos actores fueron los médicos y los estudiantes de medicina de la ciudad de México, que entre noviembre de 1964 y octubre de 1965, demandaron mejores condiciones laborales. Además de los médicos, también los ingenieros y los agrónomos demandaban una mayor influencia y poder dentro del sistema (Cleaves 1987, citado por Somuano 2010, p. 252)

Sin restar importancia a otros movimientos, como el ferrocarrilero o el de los médicos, el movimiento estudiantil de 1968 (y la represión que lo liquidó) representó un punto de inflexión en la historia política del México posrevolucionario. Básicamente se trataba de una protesta de sectores de clase media que veían que se estrechaban sus posibilidades de inserción decorosa en la sociedad y que no tenían dentro del sistema la voz que esperaban. Como señala Middlebrook, [citado por Somuano], el año 1968 fue emblemático porque por vez primera se dio un amplio debate nacional que cuestionó los alcances y el significado del "mito de la Revolución mexicana”. Es decir, la visión de progreso ascendente y de crecimiento con niveles sostenidos de redistribución, que era parte fundamental de las creencias de los mexicanos, empezó a resquebrajarse en esa coyuntura. (p.253) 
(...)El movimiento estudiantil de 1968 [fue] un detonante de la limitada apertura política que puso en práctica años después el presidente José López Portillo. (2010, p.254)

(...)El régimen requería nuevas fuentes de legitimidad y el ámbito electoral se veía como el medio idóneo para canalizar las demandas de democratización de los estudiantes, así como del movimiento de los trabajadores durante la década de los setenta y de diversos grupos de clase media. (Somuano 2010, p.254)

Otro movimiento que nació y se desarrolló a fines de los setenta es el de la defensa de los derechos humanos. En esos años se crearon varias organizaciones de derechos humanos, con el fin de dar apoyo a los refugiados centroamericanos (...)

A principios de los ochenta surgieron nuevas organizaciones, cuyo objetivo específico era justamente la defensa de los derechos humanos. Un claro ejemplo fue la Academia Mexicana de Derechos Humanos, creada en 1984 e integrada por distinguidos intelectuales y abogados. Esta organización lograría dos victorias importantes: primero, legitimar el tema entre las élites educadas del país y, segundo, constituir un espacio de reunión de distintas organizaciones gremiales y no gubernamentales (ONGs), fundamentalmente campesinas, dando inicio al movimiento en favor de los derechos humanos como tal. (Durand, 1994, citado por Somuano). (2010.p. 254) ${ }^{95}$

Otro elemento importante para el auge de las luchas y organizaciones del movimiento fue el cambio de la política exterior mexicana que había prevalecido hasta entonces. Durante la presidencia de Miguel de la Madrid, el interés gubernamental se alejó del problema de los refugiados centroamericanos y se enfocó en la situación de los derechos humanos dentro del país: tortura, persecución política, violaciones de 
derechos civiles. El informe de Amnistía Internacional de 1986 sobre violaciones de derechos humanos en México tuvo una influencia importante en ese giro. (Somuano, 2010, p.255)

Otro movimiento que surgió en los setenta es el movimiento urbano popular, el cual estaba integrado por grupos, organizaciones, coaliciones, frentes de colonos, inquilinos, solicitantes o cooperativistas que reivindicaban condiciones necesarias para la sobrevivencia de sus integrantes (tierra, vivienda, infraestructura y servicios urbanos), el reconocimiento de sus organizaciones y derechos ciudadanos, así como la participación en las decisiones sobre la ciudad y la política urbana nacional. (Ramirez Saiz, 1992)(...) El común denominador que tenían las distintas organizaciones era su independencia respecto del ámbito de influencia directa del Estado y del Partido Revolucionario Institucional (PRI). (Somuano (2010, p.256)

(...) [Entre los años 1983-1984], se crearon organizaciones locales, regionales y nacionales, se iniciaron luchas por una gran diversidad de demandas económicas y sociales, otras incursionaron también en la lucha político electoral y en la relación con los partidos legalizados (Farrera Araujo,1994) Las organizaciones que dieron lugar a la Coordinadora Nacional del Movimiento Urbano Popular (Conamup), y la coordinadora misma, fueron los principales defensores de las demandas de grupos de escasos recursos sin vivienda en el periodo previo a los sismos de 1985. Esta coordinadora desempeñó un papel muy importante como organismo aglutinador y difusor de las luchas del movimiento urbano, además de contar con una gran capacidad de movilización. (Somuano (2010, p.256)

A finales de 1993, como consecuencia y reacción ante la liberalización comercial que se produjo en México a partir de la década de los ochenta, el cambio del 
papel del Estado como rector del campo en favor de las leyes de los mercados internacionales y el retiro de los subsidios a los productores, empezó a gestarse el movimiento barzonista. A partir de la crisis económica de 1994, El Barzón empezó a aglutinar ya no sólo a productores agropecuarios, sino también a miles de deudores incapaces de pagar sus créditos, y poco a poco se le unieron diversos sectores sociales inscritos en los ámbitos de la producción agrícola, el comercio, la industria, los servicios y el consumo. A fines de 1995, El Barzón había pasado de ser un movimiento social a constituirse en una organización posicionada nacionalmente con una agenda claramente definida: evitar la pérdida del patrimonio de muchas familias y recuperar la tranquilidad de los deudores. (Somuano (2010, p.257)

Quizá el movimiento social más importante en México desde 1968 fue la rebelión zapatista de 1994. Es importante destacar que la rebelión no estaba encabezada por los sectores más marginados y pobres de la población indígena, sino por aquéllos que trataron de modernizar la comercialización del café en la Sierra Lacandona, pero que no lo lograron debido a la apertura económica indiscriminada y a la deficiente regulación del gobierno mexicano (Bizberg, 2003). Este movimiento también fue producto de la frustración que resultó de la represión sistemática, por parte del gobierno estatal de Chiapas, contra las asociaciones campesinas independientes y de la cooptación de la organización regional más importante: la Unión de Uniones de Chiapas. Esta situación bloqueó constantemente todos los canales legales de representación de estos grupos campesinos, e implicó la destrucción de los esfuerzos de organización legal e institucional por parte de la población de la región.

En un primer momento, el éxito del movimiento zapatista fue haberse reconvertido aceleradamente de una guerrilla que buscaba el poder, en un vasto 
movimiento social de gran convocatoria. Hay quienes incluso sostienen que "no ha habido una guerrilla más exitosa en América Latina, porque habiendo realizado una precaria guerra de guerrillas de 12 días, tuvo efectos políticos de gran envergadura" (Figueroa, 2005). (Somuano (2010, p.258)

El surgimiento del movimiento zapatista modificó dramáticamente el panorama de transición política en México. La rebelión condujo a la formación de un movimiento de apoyo a las luchas de los pueblos indígenas, el cual se expresó en distintas movilizaciones masivas de las clases medias urbanas. Este proceso aumentó la urgencia de una salida pacífica a la crisis política del país, acentuada por el asesinato del candidato presidencial del PRI en marzo de 1994. Sin embargo, su origen violento y su confinamiento a la zona de los Altos de Chiapas, limitaron su capacidad de extenderse a la sociedad civil e impidieron que llegara a ser un movimiento social y político más amplio. (Somuano (2010, p.258)

Otro levantamiento muy complejo y numeroso en términos de movilización fue la organización sindical de maestros apoyado por la Asamblea Popular de los Pueblos de Oaxaca (APPO), que sucedió a finales del gobierno foxista. (Somuano (2010, p.258)

El 15 de mayo de 2006, como todos las años, el magisterio oaxaqueño se movilizó para exigir rezonificación, aumento salarial y mayor presupuesto para infraestructura educativa. Ese año, los maestros acordaron no viajar al Distrito Federal y quedarse en Oaxaca, y una semana después dejaron de impartir clases para comenzar un plantón como medida de presión política para el cumplimiento de sus demandas. Un mes más tarde, las autoridades estatales decidieron acabar unilateralmente con el plantón y la policía intentó desalojar a los maestros. 
La violencia e intimidación desatadas por el intento de desalojo de los maestros provocó la insurrección contra el gobierno estatal y el aglutinamiento de diversos actores que formaron la APPO. Esta asamblea integró a organizaciones sociales, políticas, de derechos humanos, ecologistas, de género, estudiantiles, sindicales, etc., y con su formación, pasó de ser un movimiento puramente gremial a una lucha popular. (Somuano (2010, p.258)

Una vez realizada la síntesis sobre la evolución de los movimientos sociales en México, se tratarán los movimientos en articulación con los partidos políticos y sus sistemas.

Así como lo indica Somuano citada por Bizberg \& Zapata, (2010):

Esta relación de articulación consiste en que las organizaciones de los movimientos sociales se agrupan alrededor del programa de un partido político y promueven las posiciones partidistas entre los seguidores potenciales a los que los partidos esperarían movilizar en busca de apoyo y de nuevos miembros

Aun cuando los partidos políticos controlan directamente dichas organizaciones, es común que éstas ejerzan alguna influencia independiente sobre el partido. Su éxito en la movilización de masas obliga al partido a hacer más fuerte el compromiso a una causa particular. A cambio del acceso a ciertos cotos de poder en el partido y del apoyo institucional a su causa, se esperará que los activistas del movimiento sigan las líneas e instrucciones del partido.

Como ejemplo claro de este tipo de articulación es la que ha llevado a cabo en México el Movimiento Antorchista. La pieza principal de este movimiento es Antorcha Campesina, una organización política fundada en 1974 con el objetivo principal de 
CRISIS DE REPRESENTACIÓN COMO CONSECUENCIA DEL TRANSFUGUISMO POLÍTICO EN

“organizar a los sectores más marginados y pobres de la sociedad para lograr mejorar el estado de sus comunidades, luchar por una mejor distribución del ingreso y eliminar las profundas diferencias sociales" (Movimiento Antorchista, 2009). Éste movimiento ya cuenta con una Dirección Nacional. (p. 262)

Por lo expuesto anteriormente se evidencia que los movimientos sociales no cuentan con toda la gama de condiciones dadas en el contexto político, experiencia que debe llevar a considerar algunos cambios de estrategias para la formación de nuevas identidades; sin embargo, se considera que, en su momento, estos movimientos fueron piezas claves para que diferentes sectores de la población lograran satisfacer, (así fuera relativamente), sus demandas que antes de su surgimiento el estado había desconocido, ya que no habían encontrado en los partidos políticos el apoyo para alcanzar sus objetivos.

\subsubsection{Movimientos Sociales en Colombia}

Colombia en los últimos años ha mostrado avances en el crecimiento macroeconómico al insertarse en la economía mundial por medio de la firma de diversos tratados internacionales, (entre ellos los de libre comercio; los famosos TLC), a pesar de soportar un conflicto interno que por más 50 años, ha hecho que, tanto el crecimiento económico como la estabilidad democrática, se hayan sostenido en medio de protestas contra diferentes medidas tomadas por el Estado donde han participado diversos sectores productivos y sociales del país, algunos, incluso, con apoyo extranjero.

Con la Constitución de 1991, se generó un nuevo sistema político más incluyente, participativo y descentralizado. Como consecuencia de esas transformaciones, el sistema de partidos igualmente evolucionó, promoviendo cambios en la representación política como la 
CRISIS DE REPRESENTACIÓN COMO CONSECUENCIA DEL TRANSFUGUISMO POLÍTICO EN COLOMBIA

carencia de representatividad ante los sectores sociales quedando al descubierto una desvinculación de los partidos ante las movilizaciones. (Velasco, 2010).

Los cambios sufridos en el país, han dejado dos grandes damnificados: el sector agropecuario y la industria; ésta última ha tenido, en los últimos años, un descenso del 0,7\% según cifras del Dane en el año 2013. Por otro lado, siguen acrecentándose los índices de pobreza y de desigualdad social, especialmente en las zonas rurales donde se concentra la mayor parte de la pobreza.

Colombia no ha logrado construir un movimiento social capaz de crear rupturas institucionales, entre tantas razones, por la incapacidad organizativa y la debilidad en la creación de una identidad, la ausencia de recursos y el elevado costo represivo.

Esto a pesar de la existencia de 35 años de una sostenida movilización social por parte de diversos actores políticos que reconocen cómo, el uso de estos mecanismos, junto con herramientas formales, pueden entenderse como “dispositivos válidos para realizar reclamaciones" (Velasco, 2010, p. 215).

Dentro de las organizaciones sociales estructuradas y organizadas, caracterizadas por sus recursos y legitimidad dentro del sistema político colombiano; están los sindicatos, las juntas de acción comunal, las organizaciones indígenas, las organizaciones de base, los grupos cívicos, las organizaciones no gubernamentales, etc., conformadas por diferentes actores sociales, entre ellos, los asalariados, los campesinos, los grupos étnicos, los desmovilizados, las mujeres, los LGTBI, la población urbana, los ambientalistas y los estudiantes (Fundación Konrad Adenauer-KAS-Colombia, 2014).

Los actores más destacados en sus numerosas acciones colectivas, entre 1975 y 2006, fueron los pobladores urbanos trabajadores, campesinos y estudiantes, que convocaron un total del 84,6\% de las movilizaciones en ese período (CINEP, 2008). 
CRISIS DE REPRESENTACIÓN COMO CONSECUENCIA DEL TRANSFUGUISMO POLÍTICO EN COLOMBIA

La combinación de organizaciones sociales diversas y el trabajo coordinado durante las movilizaciones, u otro tipo de acciones colectivas, aseguran una capacidad mayor de articulación de las organizaciones y la construcción de un discurso común en el que se desafía al Gobierno por "el incumplimiento de los acuerdos concertados con anterioridad, sobre explotación de recursos naturales, inversión social, mejora en infraestructura y protección de territorios indígenas, así como de comunidades afrodescendientes y campesinas" (Restrepo 1990, p. 29).

La movilización estudiantil universitaria de 2011 respondió, no a una coyuntura específica; sino al resultado de tres décadas de activismo de las organizaciones estudiantiles formales e informales, constituidas al interior de las universidades públicas, las cuales, se activaron durante el proceso de reforma a la Ley 30 de educación superior.

La movilización contó con el apoyo de sectores sociales pertenecientes a universidades privadas a lo largo del país, situación que permitió la reformulación del movimiento estudiantil dando validez y legitimidad a la Mesa Amplia Estudiantil Nacional, MANE.

Sin embargo, aunque existió una acción colectiva multiforme y variada por parte de los estudiantes, ésta no tomó la forma de movimiento social en la medida en que fue un sector único de la sociedad el que se movilizó y, su meta a logar, no fue anular un cambio social fundamental, sino el retiro de una reforma que se tramitó a través de las instancias normativas e institucionales establecidas en el sistema político. (Fundación Konrad Adenauer-KASColombia, 2014)

En el caso del paro agrario nacional de 2013, sorprendió al Gobierno nacional el tipo de organización campesina que se movilizó. No eran movimientos campesinos reivindicativos en defensa de tierras frente a la violencia generada por parte de la guerrilla, paramilitares o 
CRISIS DE REPRESENTACIÓN COMO CONSECUENCIA DEL TRANSFUGUISMO POLÍTICO EN COLOMBIA

agentes del Estado; en esta ocasión, fueron organizaciones campesinas de territorios de importante producción agrícola ubicados en las zonas más fértiles del país y con una mayor presencia institucional.

La activación de una movilización de carácter nacional, liderada por parte de sectores campesinos con mayores recursos económicos, políticos y cognitivos; obligó al Gobierno a sentarse a negociar en medio de las movilizaciones y con la amenaza de un desabastecimiento alimentario, y evidenció la existencia de una organización multiforme pero con fuertes liderazgos y con capacidad de presión.

Adicional a los dos anteriores, otro sector que ha venido organizándose es el de los mineros artesanales a través de la plataforma CONALMINERCOL. Estos sostuvieron un paro total de actividades entre el 17 de julio y el 31 de agosto de 2013, cuyo resultado permitió la firma de un acta de compromiso con el Gobierno nacional, (pese a que desde algunos sectores del mismo Gobierno y líderes políticos se les ha señalado como mineros ilegales o criminales), elevando sustancialmente la movilización social en las regiones de Antioquia y Chocó, regiones de gran capacidad minera.

Es importante destacar que las movilizaciones de mineros artesanales, campesinos e indígenas, han contado con el apoyo de organizaciones ambientalistas que han venido posesionándose dentro del espectro de la acción colectiva sirviendo, por demás, como aliados estratégicos a la visibilización de sus problemáticas desde un discurso de defensa ambiental frente al impacto de los proyectos minero energéticos a gran escala.

Un elemento fundamental de la movilización es la alteración del orden público; así lo afirma (Tarrow, 1998), es "una posible amenaza de violencia, pero que demuestra la expresión concreta de la determinación del colectivo, ya que se afirma la identidad y solidaridad de los participantes, además de forzar a los oponentes a atender sus demandas” (p.132) 
Lo más destacado es que la movilización en Colombia se encuentra en un tránsito respecto al uso de nuevos repertorios de acción; en los que se destaca la movilización estudiantil universitaria de 2011, por el uso de repertorios de acción como flash mobs, elementos teatrales, el besatón, el desnudatón, el abrazatón o el carnaval de la toma de Bogotá ..., donde se rompieron los esquemas de las movilizaciones al presentar nuevas formas de protesta que fueron legitimadas y compartidas tanto por el Gobierno como por la sociedad (Fundación Konrad Adenauer-KAS-Colombia, 2014) ${ }^{76}$

Aunque el crecimiento de la economía del país parece tener resultados positivos, la frecuencia de las movilizaciones muestra que algo está pasando en relación a la efectividad de las políticas sociales y a la corrección de los graves problemas de inequidad y asimetría en la renta, problemas estructurales que, los diferentes movimientos, evidencian como graves en sus demandas. 
CRISIS DE REPRESENTACIÓN COMO CONSECUENCIA DEL TRANSFUGUISMO POLÍTICO EN

\section{Conclusiones}

Repasado el análisis realizado en el trascurso del estudio que nos ocupa, considerando los objetivos trazados y en virtud de la hipótesis planteada, procederemos a realizar un planteamiento que nos permita tener una aproximación subjetiva a la pregunta jurídica que sirvió de fundamento de esta compilación, la cual recordamos: ¿Cómo la representación de los partidos políticos se afecta con el incremento del transfuguismo político?

El estudio político visto desde sus diferentes tópicos, es muy complejo debido a que se integran; dentro del espacio interactivo entre numerosas fuerzas y pasiones, pensamientos y comportamientos sujetos a influencias de distintos órdenes difíciles de identificar, a pesar de que están siempre relacionados dentro de la dinámica intangible del poder.

En virtud del primer objetivo planteado, podemos señalar que entendemos que la política es, en otras palabras, la historia de la gente y de su relación con el poder, o expuesto de otra forma, del poder sobre ellos. Analizar las dinámicas del poder desde la estructura misma del estado, constituye un intento por desagregar el complejo proceso interminable y sorprendente de la toma de decisiones dadas por cualesquiera de las personas que ocupan los altos cargos en los diferentes órganos del Poder Público, cuyas actuaciones adelantadas; por ejemplo, dentro del Legislativo, permiten vislumbrar las motivaciones de los actores parlamentarios reflejadas en los comportamientos que se dan en la arena legislativa, quienes en aras del bien común, “negocian” con el Ejecutivo sus propios intereses, desligando los órganos del Poder Público para convertirlos en verdaderos poderes individuales, donde cada integrante busca sacar su mejor tajada. El espacio del Congreso sirve entonces, como medio 
CRISIS DE REPRESENTACIÓN COMO CONSECUENCIA DEL TRANSFUGUISMO POLÍTICO EN COLOMBIA

de interacción de procesos de acomodación y reorganización de alianzas y coaliciones políticas; sean permanentes o pasajeras, cuyas lealtades cambiantes obedecen a imperativos, mezclados y complejos intereses de mutua ayuda, llegando aún al descaro de no interesarles que sus representados los conozcan y por el contrario los van acostumbrando a exteriorizar las expresiones de así es la política, como característica de los seres humanos dedicados a la política y de ahí el aforismo que no importan que existan "roscas" si el elector se encuentra en ellas.

El efecto inmediato de todo lo anterior y la respuesta de nuestro segundo objetivo planteado, es la pérdida de legitimidad política, y como consecuencia el rezago de los sistemas políticos ante el crecimiento de ese tipo de situaciones, evidenciando cada vez más una menor capacidad de reacción ante las numerosas demandas y expectativas expuestas por los ciudadanos y por eso Colombia; en pleno siglo XXI, se encuentra arrastrando el pesado lastre de conflictos armados, producto de los desequilibrios políticos, generando una serie de consecuencias, con escaso nivel de eficiencia, en los ámbitos políticos, económicos y sociales, cuyas secuelas son ostensibles en materia de déficits de política pública.

El período de conflicto armado ha dejado una profunda huella en el campo institucional y en los valores sociales que demandan el fortalecimiento de los canales de comunicación y de una mejor institucionalidad partidista, para responder a las necesidades imperantes; la pobreza, la falta de empleo, la desnutrición, la delincuencia, la crisis fiscal, la deuda externa, entre muchos otros aspectos que impiden la construcción de mejores condiciones para el desarrollo social. 
Por otra parte la presión ejercida por los movimientos sociales; los cuales han demandado una mayor democratización de las organizaciones públicas, además de exigir mayor eficiencia y legitimidad en el rendimiento de dichas instituciones para canalizar así sus demandas, han hecho que se vuelque el enfoque hacia una democracia más directa, desconociendo no solo los principios partidistas, sino a las personas que los representan, en la medida en que los partidos políticos han promovido una cultura de acumulación electoral de forma individual sobre sus propias causas y doctrinas, las que ya no se recuerdan y menos se enseñan a los nuevos partidarios, lo que ha provocado la competencia pluripartidaria bajo estrategias de desgaste político y cuyo efecto directo es el descrédito de las instituciones de representación democrática y de los mismos partidos políticos, siendo el resultado más visible la fluidez de la oferta partidaria, que hace que la comunidad Colombiana; inmersa desde hace varias décadas en esta situación y que la ha vuelto extremadamente sensible, empiece a buscar procesos de reconstrucción de su tejido social, el cual se encuentra sumergido en la necesidad de redefinir un Estado cuya prioridad sea la reconciliación entre todos los colombianos y a la vez que sea capaz de adecuarse a las dinámicas internacionales, especialmente en el campo económico, financiero y comercial, pero a su vez que pueda ofrecer adecuadas y oportunas respuestas sociales, que solo se lograrán si la democracia colombiana sale de la encrucijada en que se encuentra y su capacidad de respuestas institucionales, empezando por atender el déficit histórico; que sigue en crecimiento, ante los problemas de la actualidad; aunque se siga distrayendo al conglomerado, con discusiones entre los líderes o jefes de las Instituciones, pretendiendo dar transparencia y pulcritud a sus funciones en aras de lograr mejores niveles de cohesión social y representación democrática. 
El estancamiento de los gobiernos; sea por ineficacia o por una sobre demanda de necesidades sociales sin oportunas respuestas, se han convertido en estandartes que abren espacios para empoderar a un nuevo grupo de actores sociales, llamados 'outsiders ' cuyo objetivo es participar en la supervivencia del poder, colaborando a que el Estado viva en constante pugna para alcanzar el fortalecimiento de la institucionalidad democrática pero debilitando sus estructuras fundamentales, entre quienes desean y hacen incidencia para una mayor gobernabilidad democrática, sin importar el engranaje institucional y entre quienes su agenda política la concentran únicamente en más gobernabilidad democrática del sistema. El desafío entonces, es encontrar y asegurar los diseños institucionales adecuados y con ellos obtener los resultados necesarios a partir de la combinación de políticas variables que actualicen permanentemente la vida del sistema.

Con fundamento en el tercer y último objetivo proyectado para esta disertación, me permito establecer que en virtud de los resultados negativos que han surgido a partir de la crisis de representación y con el propósito de contrarrestarlos y de esta manera lograr aumentar los resultados positivos necesarios en nuestro entorno social, considero que se debe propender por una reestructuración estatal constitucional de los sistemas de partidos que fortalezcan la democracia, tomando como base una nueva reintegración de los componentes que configuran las percepciones ciudadanas por medio del fácil acceso de las colectividades, dando así contestación a la falta de representación, lo que debe provenir como resultado de una mayor participación en la formulación de los programas públicos y en una mayor inclusión de los sujetos en la toma de decisiones. 
Por esto, luego del presente análisis pienso que se debe aumentar la credibilidad en la convivencia general con los partidos políticos, de tal manera que disminuyan el miedo y la desconfianza en los sistemas de éstos, generando mayor participación, interrelación y opinión del ciudadano hacia el partido de su elección. Para esta reestructuración se necesita de la unión de diversas acciones, porque si bien es cierto que en la democracia actual el ciudadano tiene derechos y deberes, la realidad es otra, precisamente porque los individuos no cuentan con representación real, que los conduzca a la satisfacción y cumplimiento de sus necesidades y derechos, siendo en consecuencia necesario superar la crisis de representación por parte de los partidos políticos, volviendo a la aplicabilidad actualizada de sus principios y valores, para que sigan siendo el mecanismo por el cual se eligen los representantes en las democracias modernas. Así es que (Stokes, 1999), ${ }^{19}$ señala que los partidos políticos son "una parte inevitable de la democracia” (p. 245), aunque (Martínez, 2009) ${ }^{20}$ manifiesta que las instituciones cuentan con escenarios partidistas, si no se parte del "(...) gran escepticismo hacia los partidos como organizaciones de representación social” (p. 139).

El fenómeno del transfuguismo materializa los problemas teóricos del ejercicio de la representación y articulación de los intereses sectoriales, dejando en evidencia las debilidades de los mecanismos de integración partidaria, específicamente las capacidades de los partidos políticos para construir y mantener la cohesión y disciplina parlamentaria. Entonces plantear reformas reglamentarias al transfuguismo implica ir más allá de la discusión del diseño institucional, pues requiere concebir a su vez las atenuaciones políticas necesarias para dar

\footnotetext{
${ }^{19}$ Stokes, S. (1999). Political Parties and Democracy. Annual Review of Political Science (2), 243-267.

${ }^{20}$ Martínez, V. (2009). Partidos y democracia (¿"Porque amores que matan nunca mueren"?). Andamios , 5 (10), 139-167.
} 
CRISIS DE REPRESENTACIÓN COMO CONSECUENCIA DEL TRANSFUGUISMO POLÍTICO EN COLOMBIA

estabilidad al sistema como un todo, más allá de la gestión particular de los actores en una administración constitucional en particular.

Es importante entender que si bien es cierto los representantes son autónomos para el desarrollo del ejercicio del cargo de elección popular, ya que los legitima el mandato otorgado en elecciones para ejercer la representatividad política que se les encomienda, ésta representación no puede considerarse en términos absolutos, pues encuentra su límite en el programa partidista que los elegidos se comprometen a realizar mientras fungen como candidatos y que les ha sido confiada por los representados, razón más que suficiente para que sean los ciudadanos quienes tengan el derecho de ejercer el control sobre los políticos que defrauden esa confianza, al apartarse del programa que prometieron respaldar, gestionar y defender, legitimadas no solo mediante el control interno, que si bien actualmente se encuentran formalmente instituido, en la realidad social no les permiten a los electores exigir una rendición de cuentas a sus representantes, ante el incumplimiento del mandato conferido, porque los procedimientos existentes son totalmente inaplicables en la forma en que están concebidos, por eso se hace necesario establecer mecanismos externos para que en forma directa el propio elector sea juez, sobre los resultados de la gestión adelantada por su representante y que debe oficializarse con lo establecido en cada partido político, especialmente cuando se retira de la colectividad, incurriendo en el fenómeno del transfuguismo, donde actualmente el sujeto tránsfuga es solo castigado por los electores, pues varios de los miembros de las Corporaciones Públicas que decidieron hacer uso de los permisos transitorios y se presentaron nuevamente a elecciones legislativas no lograron acceder a curules por niveles bajos de votación, como respuesta a la sensación de fraude en el 
CRISIS DE REPRESENTACIÓN COMO CONSECUENCIA DEL TRANSFUGUISMO POLÍTICO EN COLOMBIA

electorado y a la falta de reconocimiento en el nuevo partido político, fortaleciendo nuestra conclusión de la crisis de representación como consecuencia del trasfuguismo político.

En el caso colombiano, tal y como se pudo evidenciar en el estudio normativo histórico de nuestro marco legal, el transfuguismo político se ha dado por variables institucionales internas y externas. Las primeras toda vez que mediante los Actos legislativos, se permitió que los miembros de las corporaciones públicas incurrieran en comportamientos tránsfugas sin que se diera algún tipo de sanción, haciendo que este comportamiento se "institucionalizara" al interior de los cuerpos colegiados, pues como lo afirma la teoría, son los incentivos y restricciones dados en los reglamentos legislativos los que definen las márgenes de acción y el campo de oportunidades de los transfuguistas en las corporaciones públicas, que definitivamente rompen con la pertenencia e identidad de las ideas, doctrinas y causas que era de su responsabilidad cumplir y hacer cumplir por ser miembro de esa colectividad política y que debe haber conocido, estudiado y aplicado por convencimiento como parte de su formación integral para asumir con responsabilidad su comportamiento en la sociedad a la que pertenece, evitando así ser una veleta que solo está sometida al curso de los vientos oportunistas o de movimientos simplemente populistas.

Para corregir lo anterior, considero como otra alternativa que desde los primeros años de preparación académica, las personas reciban por parte de las estado, formación política para que no solo conozcan cómo se gobierna en el País, sino que además se estudien los partidos políticos, sus estatutos y reglamentos, y de esta manera se les facilite decidir a los jóvenes a qué colectividad política desean pertenecer, sin que sea necesario recurrir a la política de sus ancestros o a la indiferencia o aún peor a la práctica de la simple mecánica electoral de cuánto 
CRISIS DE REPRESENTACIÓN COMO CONSECUENCIA DEL TRANSFUGUISMO POLÍTICO EN COLOMBIA

vale su voto, fortaleciendo de esta manera el sistema de partidos, ya que de seguir así, es probable que en muy poco tiempo desaparezcan los partidos políticos y por ende el sistema democrático en que se sustentan, máxime cuando los incentivos a que se está acostumbrando al pueblo para que ejerza su derecho y deber electoral, lleguen a ser insuficientes, por falta de capacidad comercial del estado.

Adicionalmente y como inciso final, considero que es urgente establecer una comisión integrada por todos los estamentos existentes, tanto públicos, como privados, que se encarguen de construir un nuevo sistema de partidos, con el propósito general de fortalecer a los partidos políticos como ejes de la representación democrática, que a su vez deben llevar una base de datos de sus miembros y representantes, que les permita sancionar; a quien se convierta en trásfuga, con la suspensión definitiva del ejercicio de la representación ciudadana.

Así las cosas y en virtud de lo señalado a lo largo de este trabajo realizado, hemos podido confirmar la Hipótesis planteada en cuanto a que la crisis de la representación de los partidos políticos en Colombia ha venido en aumento, por la incapacidad de las organizaciones políticas para realizar eficiente y eficazmente sus funciones. Igualmente toda vez que se mantiene una excesiva burocratización, la que se forma desconociendo mecanismos de selección, conllevando a un crecimiento desmedido de la maquinaria estatal; se genera una manifiesta corrupción en diversos niveles de la administración pública, aunada a los bajos niveles de control, lo cual evidencia el descrédito que sufren actualmente las diferentes instituciones políticas entre las que mayormente se destacan los partidos políticos. 
CRISIS DE REPRESENTACIÓN COMO CONSECUENCIA DEL TRANSFUGUISMO POLÍTICO EN COLOMBIA

\section{Referencias}

Abal, J. (2004). La muerte y la resurección de la representación política. Buenos Aires: Fondo de Cultura Económica.

Alcántara. (1996). "Un esquema de análisis para el estudio de los partidos en proceso de transición: fundación frente a tradición". Barcelona: Papers 49. Universidad Autónoma de Barcelona.

Alcántara, M. (1996). "Un esquema de análisis para el estudio de los partidos en proceso de transición: fundación frente a tradición". Barcelona: Papers 49. Universidad Autónoma de Barcelona.

Alcántara, M. (1997). Las tipologías y las funciones de los partidos políticos. Madrid: Trotta.

Alcántara, M., del Campo, E., \& Ramos, M. (2001). La naturaleza de los Sistemas de Partidos Políticos y su Configuración en el marco de los Sistemas Democráticos en América Latina. España: Comisión Interministerial de Ciencia y Tecnología de España.

Aranzamendi, L. (2006). Municipios y democracia participativa. Arequipa - Perú: Adrus. 
CRISIS DE REPRESENTACIÓN COMO CONSECUENCIA DEL TRANSFUGUISMO POLÍTICO EN COLOMBIA

Artiga, A. (2000). La política y los sistemas de partidos en Centroamérica. San Salvador: Fundaungo.

Bartolini, S. (1995). "Partidos y sistema de partidos". En G. Pasquino, S. Bartolini, M. Cotta, L. Morlino, \& A. Panebianco, Manual de ciencia política. España: Alianza Editorial.

Bizberg, I., \& Zapata, F. (2010). Movimientos Sociales. En I. Coordinadores Bizberg, \& F. Zapata, Los grandes problemas de México. México D.C.: El Colegio de México.

Burke, E. (1774). "Discruso a los electores de Bristol". Recuperado el 11 de 2014, de Constitución WEB: http://constitucionweb.blogspot.com/2010/12/discurso-los-electores-debristol.html

Burnham, W. D. (1982). The Current Crisis in American Politics. New York: Oxford University Press.

Carbonell, J. (2002). El Fin de las Certezas Autoritarias, Hacia la Construcción de un Nuevo Sistema Político y Constitucional para México. México: UNAM.

Carpizo, J., \& Madrazo, J. (s.f.). Derecho Constitucional. Recuperado el 5 Diciembre de 2014, de Biblio Jurídicas: http://biblio.juridicas.unam.mx/libros/1/325/14.pdf 
CRISIS DE REPRESENTACIÓN COMO CONSECUENCIA DEL TRANSFUGUISMO POLÍTICO EN COLOMBIA

Carré del Malberg, R. (1998). Teoría General del Estado. México: Fondo de Cultura

Económica.

CINEP. (2008). Informe Cinep. www.cinep.org.co/index.php?option=com_docman\&task.

Colomer, J. (1990). El Arte de la Manipulación Política. Barcelona: Anagrama.

Constitución Política de Colombia. (2014). Bogotá, D.C.: Legis.

Contraloría General de la República. (2010). El Nuevo Ajedréz Político. (J. F. Osorio, Ed.) Bogotá.

Converse, P., \& Pierce, R. (1986). Political Representation in France. Cambridge: Harvard University Press.

Corporación Latinobarómetro . (28 de Octubre de 2011). Informe 2011. Recuperado el 10 de Noviembre de 2014, de Latinobarómetro: www.latinbarómetro.org

Corte Constitucional, 2006 Sentencia C-859/2006. Magistrado Ponente Dr. Humberto Antonio Sierra Porto. Consulta electrónica

Criado de Diego, M. (2012). Sobre el concepto de representación política: lineamientos para un estudio de las transformaciones de la democracia representativa. Revista Derecho del Estado - Universidad Externado de Colombia (28), 77-114. 
CRISIS DE REPRESENTACIÓN COMO CONSECUENCIA DEL TRANSFUGUISMO POLÍTICO EN

Cuéllar, M. (Junio de 2012). Análisis Técnico Jurídico del Transfuguismo Político como causa de ineficacia del Congreso de la República de Guatemala. Recuperado el 10 de Septiembre de 2014, de Universidad de San Carlos de Guatemala: http://biblioteca.usac.edu.gt/tesis/04/04_10700.pdf

Curreri, S. (2004). Democrazia e Rappresentanza Politica: dal divieto di mandato al mando di partito. Firenze: University Press.

Dagnino, E. (2002). Sociedad Civil, esfera pública y democratización. En E. Dagnino, América Latina: Brasil, México (págs. 78-102). Méico: Fondo de Cultura Económica.

Dahl, R. (1999). La democracia. Una guía para los ciudadanos. Madrid: Taurus.

Ed. Fondo de cultura económica, Mexico.2014

Fortin, J. (2010). Transfuguismo Parlamentario en Guatemala: Un caso de Altos Costos de Asociación, Monopolio Partidario y Bajos Costos de Transacción. América Latina Hoy (54), 141-166.

Fundación Konrad Adenauer-KAS-Colombia. (2014). Partidos Políticos en Colombia. Evolución y prospectiva. (H. Gehring, Ed.) Bogotá. 
CRISIS DE REPRESENTACIÓN COMO CONSECUENCIA DEL TRANSFUGUISMO POLÍTICO EN

García, J. (1996). La Democracia en España. Madrid: Alianza Editorial.

García, E. (2014). Análisis del tratamiento jurídico - político de la doble militancia política en Colombia. Cali: Universidad ICESI - Tesis de Grado.

García-Pelayo, M. (2005). "El Estado Social y democrático de Derecho en la Constitución Española". En M. García-Pelayo, Las transformaciones del Estado contemporáneo (págs. 92-104). Madrid: Alianza Editorial.

Gargarella, R. (2002). Crisis de la representatividad política. México: Fontamara.

Gaxie D (2004). La Democracia Representativa, $1{ }^{\text {ed }}$ Santiago LOM (Colección Serie Universitaria)

Godoy, O. (2001). Representación y Democracia. Revista de Ciencia Política , XXI (2), 18-68.

González, E. (Mayo de 2006). El sistema de partidos en México. Recuperado el 16 de Enero de 2015, de D.R. Convergencia: http://www.convergenciamexico.org.mx/sispart.pdf

Heller, H. (1963). Teoría del Estado. México: Paidós. 
CRISIS DE REPRESENTACIÓN COMO CONSECUENCIA DEL TRANSFUGUISMO POLÍTICO EN COLOMBIA

Henriquez, N. (2010). Gobernabilidad, Legitimidad y Participación. El Chile que no se quiere. La necesidad de una reforma constitucional. Espacio Abierto Cuaderno Venezolano de Sociología, 19 (4), 653-662.

Hernández Bravo, J. (1997). "La delimitación del concepto de partido político. Las teorías sobre el origen y evolución de los partidos". En M. (. AA.VV. Mella Márquez, Curso de Partidos Políticos. Cap. II (págs. 203-277). Madrid: Akal Ediciones.

Iglesias, M. (1984). El Pensamiento de Montesquieu. Madrid: Alianza Editorial.

Ikenberry, G. (1988). "Conclusion: An Institutional Approach to American Foreign Economic Policy". En G. Ikenberry, D. Lake, \& M. (. Mastanduno, The State and American Foreing Economic Policy (págs. 220-224). New York: Cornell University Press.

Inglehart, R. (1990). Culture Shift in Advanced Industrial Society. Princeton: Princeton University Press.

Kelsen, H. (1977). Esencia y valor de la democracia. Madrid: Guadarrama.

Kerz, M., \& Pomposo, H. (2006). Algunas tesis sobre democracia-representación y partidos políticos. Trayectoria de los partidos políticos en la democracia argentina. Recuperado el Febrero de 2015, de Universidad de Belgrano. Documento de Trabajo No. 152: http://www.ub.edu.ar/investigaciones/dt_nuevos/152_kerz.pdf 
CRISIS DE REPRESENTACIÓN COMO CONSECUENCIA DEL TRANSFUGUISMO POLÍTICO EN COLOMBIA

Lijphart, A. (1990). The political consequences of electoral laws, 1945-1985. American Political Science Review (84), 482-496.

Luna, J. (2014). ¿Crisis de legitimidad en Chile? Movilizaciones sociales y sistema político. Bogotá: Fundación Konrad Adenauer Stiftung.

Mair, P. (1998). Party System Change. Approaches and Interpretations. Oxford: Clarendon Press.

Maíz, R. (2007). Nación y revolución: la teoría política de Emmanuel Sieyés. Madrid: Tecnos.

Mallén, T. (2002). Transfuguismo parlamentario y democracia de partidos. Madrid: Centro de Estudios Políticos y Constitucionales.

Manin B. (1992) "Metamorfosis de la Representación" en Dos Santos Mario (coord.)" Que queda de la Representación Política" CLACSO - Nueva sociedad- Caracas 1992

Manin, B. (1998). Los principios del gobierno representativo. Madrid: Alianza.

Mansbridge, J. (2003). Rethinking Representation. American Political Science Review , 97 (4), 515-528. 
CRISIS DE REPRESENTACIÓN COMO CONSECUENCIA DEL TRANSFUGUISMO POLÍTICO EN COLOMBIA

Martínez, V. (2009). Partidos y democracia (¿"Porque amores que matan nunca mueren"?). Andamios , 5 (10), 139-167.

Mateus, J., y Velasco, J. (2010). La objeción de concienciacomo derecho constitucional en la legislación colombiana y su estudio en el derecho comparado. Bucaramanga: Universidad Industrial de Santander - Tesis de Grado.

Montero, J., \& Gunther, R. (2004). "Los estudios sobre los partidos políticos: una revisión crítica". POSTData (10), 305-337.

Noria, O. (1999). La teoría de la Representación Política del Abate Sieyés. Caracas: Universidad Católica Andrés Bello.

Oñate, P. (1997). "Los partidos políticos". En R. Del Águila, Manual de Ciencia Política (págs. 251-269). Madrid: Trotta.

Paramio, L. (2002) “La Crisis De La Política En América Latina” Unidad de Políticas Comparadas Ediciones Universidad de Salamanca.

2002, (pp. 15-28)

Panebianco, A. (1990). Modelos de Partido. Madrid: Alianza Universidad.

Pantoja, D. (1993). Escritos políticos de Sieyés. Fondo de Cultura Económica (52), 63-114. 
Passarelli, F. (2011). Un Análisis Económico del Transfuguismo Político. Recuperado el 22 de Marzo de 2015, de Universidad Pablo de Olavide, de Sevilla: http://www.upo.es/econ/master/Trabajos/Tesina_1-2011.pdf

Perícola, M., \& Linares, G. (s.f.). El transfuguismo político como elemento distorsionador de la representación política. Recuperado el Septiembre de 2014, de Universidad de Buenos Aires: http://www.derecho.uba.ar/publicaciones/pensar-enderecho/revistas/3/el-transfuguismo-politico-como-elemento-distorsionador-de-larepresentacion-politica.pdf

Pitkin, H. (1985). El concepto de representación. Madrid: Centro de Estudios Constitucionales.

Porras, A. (1994). Representación y democracia avanzada. Madrid: Centro de Estudios Constitucionales.

PNUD - OEA. (2010). Nuestra Democracia. México: Fondo de Cultura Económica.

Restrepo, L. (1990). "Los movimientos sociales, la democracia y el socialismo". Análisis político (5), 53-80.

Rey Salamanca, F. (2014). Teoría de la Representación Política en el Derecho Público (Vol. Colección Monografías N³6). Bogotá: Pontificia Universidad Javeriana. 
CRISIS DE REPRESENTACIÓN COMO CONSECUENCIA DEL TRANSFUGUISMO POLÍTICO EN

Rosales, R., \& Rojas, M. (2012). Representación, partidos políticos y procesos electorales . Recuperado el 08 de Noviembre de 2014, de Estudios políticos de Costa Rica. Cuadernos didácticos sobre teoría y práctica de la democracia. Cuaderno No. 2: www.estudiospoliticos.ucr.ac.cr

Rosales, R., \& Rojas, M. (2012). Representación, Partidos Políticos y Procesos Electorales. Costa Rica: Instituto Interamericano de Derechos Humanos IIDH.

Rucht, D. (1996). "The Impact of Nacional Contexts on Social Movement Structures: A Cross-Movement and Cros-National Comparison". En D. McAdam, J. McArthy, \& M. (. Zald, Comparative Perspectives on Social Movements: Opportunities, Mobilizing Structures and Cultural Framings (págs. 185-204). Cambridge: Cambridge University Press.

Sartori, G. (1994). Ingeniería constitucional comparada. México D.F.: Fondo de Cultura Económica.

Sartori, G. (2002). Partidos y Sistemas de Partidos. Madrid: Alianza.

Sartori, G. (2005). ¿Qué es la democracia? Madrid: Alianza Editorial.

Scully, T., \& Mainwaring, S. (1997). la institucionalización de los sistemas de partidos en América Latina. América Latina, Hoy. Revista de Ciencias Sociales, 16, 91-108. 
CRISIS DE REPRESENTACIÓN COMO CONSECUENCIA DEL TRANSFUGUISMO POLÍTICO EN COLOMBIA

Stokes, S. (1999). Political Parties and Democracy. Annual Review of Political Science (2), 243-267.

Stuart, J. (2001). Consideraciones sobre el gobierno representativo. Madrid: Alianza.

Tarrow, S. (1998). El poder en movimiento: los movimientos sociales, la acción colectiva y la política. Madrid: Editorial Alianza.

Tocqueville, A. (1961). De la Démocratie en Amérique. Paris: Gallimard.

Tocqueville, A. d. (1969). El Antiguo Régimen y la Revolución. Madrid: Guadarrama.

Torres del Moral, A. (1982). "Crisis del mandato representativo". Revista de derecho político (14), 9-22.

Valenzuela, A. (2003). El Quiebre de la Democracia en Chile. Santiago de Chile: Universidad Diego Portales, Colección Política.

Vega, P. (. (1996). En torno a la crisis de las ideas de representación y legitimidad en la democracia actual (Vol. 42). Bogotá: Universidad Externado de Colombia, Temas de derecho Público.

Velasco, M. (2010). Democracia, gobernabilidad y movimientos sociales en Colombia 1990 - 2006. En F. Jácome, \& M. Tanaka, Desafíos de la gobernabilidad 
CRISIS DE REPRESENTACIÓN COMO CONSECUENCIA DEL TRANSFUGUISMO POLÍTICO EN COLOMBIA

democrática, reforma institucionales y movimientos sociales en la región andina (págs. 155268). Lima: IDRC-CRDI, Invesp.

Vera, J. (1997). La crisis del mandato representativo en el sistema electoral de listas: El transfuguismo político. Studia Carande , 131-160.

Ware, A. (2004). Partidos políticos y Sistemas de partidos. Madrid: Ediciones Istmo, S.A.

Weber, M. (1964). Economía y Sociedad. México: Fondo de Cultura Económica.

Zovatto, D. (2006). Regulación jurídica de los partidos políticos en América Latina. México: UNAM-IDEA.

Zovatto, D. (2011). Reforma político-electoral e innovación institucional en América Latina durante la Tercera Ola Democrática (1978-2009) Tesis Doctoral publicada por la Fundación Ortega-Marañón. Madrid: Universidad Complutense de Madrid.

Zovato, D., \& Orozco, J. (2008). Reforma política y electoral en América Latina 1978-2007. México: UNAM.

Zwerg-Villegas, A. (2012). La Oligarquía y el Establecimiento como constructos históricos sociológicos. Aposta. Revista de ciencias sociales (55). 
CRISIS DE REPRESENTACIÓN COMO CONSECUENCIA DEL TRANSFUGUISMO POLÍTICO EN COLOMBIA

\subsection{Publicaciones}

Armenta, Aldo Muñoz. "El SNTE y Nueva Alianza: del control político del magisterio a la cohabitación pragmática electoral", Cotidiano Revista de la Realidad Mexicana/01861840 20110901

Bartolo, Moisés Sinuhé García. "Las reformas electorales a nivel federal en México", Cotidiano - Revista de la Realidad Mexicana/01861840, 20110501

Ben Holland. "Sovereignty as Dominium? Reconstructing the Constructivist Roman Law Thesis1 : Sovereignty as Dominium?" International Studies Quarterly, 06/07/2010

Cordero, Guillermo, and José Ramón Montero "Against Bipartyism, Towards Dealignment? The 2014 European Election in Spain", South European Society \& Politics, 2015.

Ginieniewicz, Jorge. "The Weight of Social Assets: Argentinean Migrants in Spain", European Review of Latin American \& Caribbean Studies (Centre for Latin American Research \& Documentation (CEDLA)), 2012

Losada, Rodrigo. "Los partidos y la representación política en proceso de cambio", CIVILIZAR: Ciencias Sociales y Humanas 2012 
CRISIS DE REPRESENTACIÓN COMO CONSECUENCIA DEL TRANSFUGUISMO POLÍTICO EN COLOMBIA

NERI, Daiana. "El Sistema Politico Rionegrino Frente a la Desnacionalización Politica: 1983- 2011", Colección, 2012

Rivas, José Antonio. "Desinstitucionalización de los partidos y militarización de la política en Venezuela", Reflexión Politica/01240781 20091201

Tagle, Silvia Gómez. "The Impact of the Indigenous Movement on Democratization: Elections in Chiapas (1988-2004)", Canadian Journal of Latin American and Caribbean Studies, 2005

\subsubsection{Trabajos De Estudiantes}

Submitted to Universidad EAFIT

Submitted to Pontificia Universidad Católica del Perú

Submitted to Universidad Sergio Arboleda

Submitted to Blinn College

Submitted to Universidad Francisco Marroquín

Submitted to 53250

Trabajo del estudiante Submitted to King's College

Submitted to Universidad Carlos III de Madrid

Submitted to University of Westminster

Submitted to Universidad Adolfo Ibáñez

Submitted to University of Houston System 
CRISIS DE REPRESENTACIÓN COMO CONSECUENCIA DEL TRANSFUGUISMO POLÍTICO EN COLOMBIA

Submitted to Facultad Latinoamericana de Ciencias Sociales (FLACSO) - Sede

Ecuador

Submitted to University of Aberdeen

Submitted to Atlantic International University

\subsubsection{Fuentes de Internet}

www. aaginonc.org.ar

www. aecpa.es

www. alainet.org

www. angarmegia.iespana.es

www. aplica.uptc.edu.co

www. autoestudio.uprrp.edu

www. bib.minjusticia.gov.co

www. blog.plataformac.org

www.cienciadelapolitica.files.wordpress.com

www. códigodeinfancia-dayana.blogspot.com

www.colnodo.apc.org

www. colombiainternacional.uniandes.edu.co

www consejodeestado.gov.co

www. corte-constitucional.vlex.com.co

www. 2010.colmex.mx

www. derechos.org.ve

www. didactica2004.galeon.com 
CRISIS DE REPRESENTACIÓN COMO CONSECUENCIA DEL TRANSFUGUISMO POLÍTICO EN COLOMBIA

Www. diccionario crítico de ciencias sociales

www. elciudadano-bibliotecario.blogspot.com

www. eprints.ucm.es

Www. es.slideshare.net

www. escribireneltiempo.blogspot.com

www. flacsoandes.org

Www. html.rincondelvago.com

www. institutodepoliticaydemocracia.blogspot.com

www.laguarura.net

www. llt.msu.edu

www. losperiodistas.fremac.org.mx

www. mesadegenerocolombia.org

www. onlinelibrary.wiley.com

www. padreivan.com

www.partidoconservador.org

www. pauloarboledaramirez.blogspot.com

www. pciudadana.com

www. periodico.morelos.gob.mx

www.queridodiario.lasillavacia.com

www.rcci.net

www. repository.javeriana.edu.co

www. repository.urosario.edu.co

www. revistargumentos.org.pe

www. revistas.ojs.es 
CRISIS DE REPRESENTACIÓN COMO CONSECUENCIA DEL TRANSFUGUISMO POLÍTICO EN COLOMBIA

www. sisbib.unmsm.edu.pe

www.tintaysangre.files.wordpress.com

www.universoagora.com.ar

www. viajes.euroclips.com

web.mit.edu

www.24horaslibre.com

www.alipso.com

www.ambientalista.org.mx

www.apunto.com.ve

www.calarca.net

www.cepal.cl

www.cepchile.cl

www.charrymosquera.com

www.clad.org.ve

www.cne.gov.co

www.cne.org.bo

www.colmex.mx

www.confedelca.com

www.congresogto.gob.mx

www.corteconstitucional.gov.co

www.cs.usb.ve

www.democraciapartidos.org.bo

www.eafit.edu.co

www.ejournal.unam.mx 
CRISIS DE REPRESENTACIÓN COMO CONSECUENCIA DEL TRANSFUGUISMO POLÍTICO EN COLOMBIA

www.elabedul.net

www.e-local.gob.mx

www.esquinamagica.com

www.eurosur.org

www.fcs.edu.uy

www.fractal.com.mx

Www.gacetaputumayo.gov.co

Www.getempo.org

www.gobernabilidad.cl

www.iberoconstitucional.com.ar

www.icpcolombia.org

www.icps.cat

www.ieechihuahua.org.mx

www.iepct.org.mx

www.iesam.csic.es

www.ife.org.mx

www.iidh.ed.cr

www.iij.derecho.ucr.ac.cr

www.ilog.es

www.imca.org.ve

www.ip-watch.org

www.joseluisariasrey.com

www.jourdan.ens.fr

www.juntadeandalucia.es 
CRISIS DE REPRESENTACIÓN COMO CONSECUENCIA DEL TRANSFUGUISMO POLÍTICO EN COLOMBIA

www.kas.de

www.legebiltzarra.net

www.leyex.info

Www.manosunidas.org

www.mensaje.cl

www.migracionescolombianas.edu.co

www.mij.gov.co

www.milenio.com

www.monografias.com

www.navarro.cl

www.ndipartidos.org

www.obelia.org

www.ort.edu.uy

www.partidoverde.org.co

www.pnud-gobernabilidaddemocratica.org

www.presupuesto.gobierno.pr

www.profesorgentile.com.ar

www.razonypalabra.org.mx

www.red-redial.net

www.researchgate.net

www.revistaestudios.unc.edu.ar

www.sagarpa.gob.mx

www.scielo.org.mx

www.scielo.unal.edu.co 
CRISIS DE REPRESENTACIÓN COMO CONSECUENCIA DEL TRANSFUGUISMO POLÍTICO EN COLOMBIA

www.secotab.gob.mx

www.slideshare.net

www.socsci.uci.edu

www.te.gob.mx

www.uabjo.mx

www.ub.edu.ar

www.ucm.es

www.udesa.edu.ar

www.umh.es

www.unavarra.es

www.undp.un.hn

www.universidadabierta.edu.mx

www.upo.es

www.wege-europas.de

www2.scjn.gob.mx

www.xa.yimg.com 